\title{
Danişmen Formasyonu Stratigrafisi ve Birim İçindeki Linyit Düzeylerinin Havzadaki Dağılımı, Trakya Havzası, Türkiye
}

\author{
Sratigraphy of the Danişmen Formation and distribution of lignite seam layers interbedding in \\ the Unit, Thrace Basin, Turkey
}

\author{
Doğan PERINCÇEK ${ }^{1}$, Nurdan ATAŞ ${ }^{1}$, Şeyma KARATUT ${ }^{1}$, Esra ERENSOY ${ }^{1}$ \\ ${ }^{1}$ Çanakkale Onsekiz Mart Üniversitesi, Mühendislik Fakültesi, Jeoloji Mühendisliği Bölümü, \\ Çanakkale(perincek@yahoo.com,perincek@comu.edu.tr)
}

Öz

Trakya Havzası'nın linyit potansiyeli havza genelinde yer altı verileri kullanılarak çalışılmıştır. Bu çalışmada TPAO, MTA ve TKİ kuruluşlarınca sağlanan çok sayıda kuyu verisi ve sismik veri kullanılmıştır. Amaç Danişmen Formasyonu (Oligosen-Erken-Miyosen) içinde yer alan linyit katkılarının ekonomik değerlendirmesini yapmaktır. Bu nedenle Ergene-Kırcasalih (Geç Miyosen-Pliyosen) formasyonlarının toplam kalınlık haritası hazırlanmıştır. Ayrıca çalışmanın ana hedefi olan ve genellikle Danişmen Formasyonu'nun orta kesiminde yer alan linyit katkılarının toplam kalınlık haritası hazırlanmıştır. Havzada Danişmen Formasyonu linyit katkılarının yanal değişimlerini ortaya çıkarmak için korelasyonlar hazırlanmıştır.

Danişmen Formasyonu içindeki linyit katkılarına ulaşmak için ilk engel en üsteki Ergene-Kırcasalih formasyonlarının kalınlığıdır. Bu birimlerin ve Danişmen Formasyonunun kalınlık dağılımını kontrol eden faktör Orta Miyosen sırasında etkin olan Trakya Fay Sistemi'dir. Trakya Fay Sistemi'nin fay zonları üzerinde ve dolayında oluşan yükselimler üzerinde Danişmen Formasyonu aşınmıştır. Danişmen Formasyonu'nun tamamen veya kısmen aşındığı alanlarda, linyit katkıları da yok olmuştur.

Trakya Fay Sistemi’nin etkisiyle oluşan yükselim alanları aşınmaya rağmen yüksekliklerini korumuşlar. Söz konusu paleoyükselim alanlarında Ergene - Kırcasalih formasyonları düşük kalınlıklarda çökelmiştir.

Çalışma kapsamında gerçekleştirilen kuyular arası litoloji korelasyonları yardımıyla Danişmen Formasyonu içindeki linyit seviyelerinin yanal kalınlık değişimleri ve süreksizlikleri ortaya çıkarılmıştır. Ayrıca Danişmen Formasyonu üzerinde yer alan Ergene-Kırcasalih formasyonlarının ince olduğu kesimler saptanmıştır. Böylece linyite kolay ulaş1lacak alanlar örtünün ince olduğu yerler saptanmıştır

Anahtar Kelimeler: Danişmen Formasyonu, Kuyu Logu Korelasyonu, Linyit, Trakya Fay Sistemi, Trakya Havzas 1 


\section{ABSTRACT}

Aim of this study to understand lignite potential of the basin. This work has been conducted using subsurface data; including numerous wells and several seismic lines provided by TPAO, MTA and TKI.

Purpose of this work to understand economical values of lignite seam layers interbedding in the Danismen Formation (Oligocene-Early Miocene). For that purpose, first total thickness map of Ergene-Kircasalih formations (Late Miocene-Pliocene) prepared. Total thickness of the lignite layers mapped, which is main purpose of the work. Lignite seam layers are usually located in middle of the Danişmen Formation. Also several stratigraphic correlations conducted to understand lateral continuation of lignite layers.

First obstacle to reach lignite is thickness of the Ergene-Kircasalih formations which are overlying lignite bearing Danişmen Formation. Main structural event which is controlling thickness variation of the Danismen Formation is Thrace Fault System; it was active during Middle Miocene. Danişmen Formation extensively or partially eroded along the fault zone and on the en-echelon folds of fault system. Amount of erosion is variable, Danişmen Formation and embedded lignite seams were completely eroded in some areas.

Elevated areas related Thrace Fault System partially eroded, however these areas were still paleohigh during accumulation of Ergene-Kircasalih formations. Onlapping sequence of Ergene-Kircasalih formations are thinner on these paleohigh.

At the end of this project lateral thickness variation and discontinuities of the lignite interbeds have been delineated by well log correlations. Addition to that, thin overburden areas of lignite bearing Danişmen Formation are located by mapping thickness of overlying Ergene-Kircasalih formations.

Keywords: Danişmen Formation, Lignite, Thrace Basin, Thrace Fault System, Well Log Correlation

\section{GİIŞ}

Trakya Havzası'nın linyit imkanların ortaya çıkarılmasına yönelik bu çalışmanın gerçekleşmesi için gerekli yeraltı jeolojisi veri seti TKİ, TPAO ve MTA tarafından sağlamıştır. Veri seti içinde sı ̆g ve derin kuyu verileri, sismik kesitler, bazı kuyulardan alınan karot bilgisi bulunmaktadır. TKİ tarafından açılan kuyular Trakya Havzası'nda Vize GB's1, Hayrabolu batısı ve UzunköprüPehlivanköy dolayında olmak üzere 3 alanda yoğunlaşmaktadır.

Çalışma sırasında linyit amaçlı kuyular açılırken karşılaşılacak ilk engel Ergene Formasyonu kalınlığıdır. $\mathrm{Bu}$ formasyonun kalınlığının havza bazında değişimini öğrenmek için Trakya Havzası'nın tümünde Ergene
Formasyonu kalınlık haritası yapılmıştır. Yapılan diğer bir kalınlık haritası ise toplam linyit kalınlık haritasıdır. Bu harita da ancak bölgesel ölçekte yapılırsa çalışmanın amacına hizmet edeceğinden ötürü Trakya Havzası'nın kuzey-kuzeydoğu alanları için yapılmıştır ve linyit birikimlerinin yoğunlaştığı bataklık ve göl alanlarının yerlerini dolaylı olarak göstereceği için linyit aramalarında önemli olan yol gösterici haritalardır. Linyit seviyeleri fasiyes değişimi ve aşınma nedeniyle yanal yönde süreksizlik gösterir.

Trakya Havzası'nın kuzeyinde Istranca, batısında Rodop masifleri ve güneyinde Sakarya Kitas1 yer alır. Istranca Masifi altta gnaysik kayalar ve bunların üzerinde yeşilşist fasiyesinde 
metamorfize olmuş Paleozoik, Mesozoyik yaşı sedimanter kayalarla temsil olunur (Üşümezsoy 1982, Taner ve Çağatay, 1983). Sedimanter kayalar Geç Kretase yaşlı granodiyoritik kayalar tarafından etkilenmiş ve yer yer yine Geç Kretase yaşlı volkano-sedimanter bir birim tarafından örtülmüşlerdir (Taner ve Çağatay,1983). Istranca Masifinin güney yamacında granitik kayalar mostra verir (Öztunalı ve Üşümezsoy, 1979).

Trakya Havzas1, petrol ve gaz içermesi nedeni ile, yoğun jeolojik araştırmaların gerçekleştirildiği bir bölge olmuştur. Trakya Havzası'nı tümden ele alan başlıca çalışmalar arasında Kopp ve diğ. (1969), Turgut ve diğ. (1983, 1991), Saner (1985), Siyako (2006a, 2006b) sayılabilir. Trakya Havzası'nın stratigrafik adlaması açısından en önemli kaynak ise bölgenin MTA Genel Müdürlügü tarafından hazırlanmış jeoloji haritalarıdır (İmik, 1988; Umut, 1988a, Çağlayan ve Yurtsever, 1998, Şentürk ve diğ., 1998 a, b).

Orta ve Kuzey Trakya'da Miyosen ve sonrası birimler, Eosen-Oligosen istifini örter. Bu nedenle; Trakya Havzası'nın litostratigrafik çatısı Güney Trakya, Gelibolu Yarımadası, Bozcaada ve Gökçeada'da görülen mostralar ile Kuzey Trakya'daki sismik kesitler ve açılan petrol arama kuyularından elde edilen bilgilerle kurulabilmektedir. Trakya Havzası'na ait Eosen-Oligosen istifleri Marmara Denizi güneyinde Biga Yarımadası'nda (Siyako ve diğ., 1989), Mudanya-Tirilye arasında, Armutlu Yarımadası'nda da (Akartuna, 1968) mostra verir. Dolayısıyla Trakya Havzası'nın güney sınırı belirgin değildir (Siyako, 2006b).

Trakya Havzas1, Orta-Eosen Pliyosen yaşlı birimlerin (Şekil 2) yer aldığı, üçgen şekilli, dağ arası bir Tersiyer havzasıdır (Keskin, 1974). Havzada sedimantasyon muhtemelen Erken Eosen esnasında transgresif bir istifle başlamıştır (Keskin, 1974, Doust ve Arıkan, 1974, Turgut ve diğ., 1983, Saner, 1985). Sedimantasyon, kesiklikler ve aşınmalar göz ardı edilirse, yakın zamanımıza kadar devam etmiştir. Havzanın temelini metamorfik karmaşık oluşturur. Istranca Dağları güney eteklerinden başlayarak mostra veren ve hemen hemen Trakya'nın tamamını kapsayan (Şekil 1) Tersiyer istifi 9000 metre kalınlığ 1 geçmektedir (Kopp ve diğ., 1969; Turgut ve diğ., 1983; Turgut ve diğ., 1991; Perinçek, 1987; Görür ve Okay, 1996; Turgut ve Eseller, 2000; Siyako, 2005, 2006a, 2006b). Trakya Havzası Tersiyer birimleri genellikle klastiklerden oluşmakta, şelf alanlarında ve havza ortası sırt ve yükseklerde ise karbonatları da içermektedir. Bu birimler, aralarında önemli yükselme ve aşınma evreleri olan havzalarda ve yedi ayrı zaman aralığında çökelmiştir (Şekil 1 ve 2). Havzanın orta kesimlerde sedimantasyon kısmen devamlıdır, bazı kesimlerde ise zaman zaman kesikliklerin ve aşınma evrelerinin olduğu görülür. Havza oldukça hızlı çöken ve çöktükçe dolan bir evrim geçirmiştir.

Başlangıçta düzensiz topografyanın çukurlarını dolduran istifin, kara yönünde temel üzerindeki transgresif aşmaları (onlap) çok sayıdaki sismik kesitte gözlenir (Burke ve Uğurtaş 1974; Perinçek, 1987; Turgut ve diğ., 1991).

Eosen transgresyonu Erken Oligosende maksimum düzeye ulaşmıştır. Orta Eosen Erken Oligosen de havzanın derin kısımları yoğunluk akıntılarıyla taşınan türbiditik çökellerle doldurulurken, kuzeydeki şelf ve Kuleli - Babaeski yükseliminde karbonatlar çökelmiştir (Turgut ve diğ., 1983; Keskin, 1974). Bu esnada Trakya Havzası büyük bir nehrin oluşturduğu delta sistemin etkisindedir. Buna bağlı denizaltı yelpazeleri oluşmuştur (Turgut ve diğ., 1983). Geç Eosen Erken Oligosen döneminde aktif volkanizma ürünü olan dasitik ve andezitik küller havzadaki sedimanlar içinde katkılar oluşturur (Doust ve Arıkan, 1974; Turgut ve diğ., 1983). Eosen transgresyonu, Orta Oligosen-Alt Miyosen aralığında regresyon dönemi 
izlemiştir (Keskin, 1974; Ediger, 1982, 1988; Turgut ve diğ., 1983; Saner, 1985). Orta Miyosen'deki bir çökelmezliği takiben Geç Miyosen? - Erken Pliyosen yaşlı Ergene ve Kırcasalih formasyonları çökelmiştir. $\mathrm{Bu}$ birimlerin karasal palinofasiyes içeriğini Ediger (1982) tanımlanmıştır. Çökelmezlik Orta Miyosen sırasında gelişmiş olup, ince kırıntılı karasal Geç Miyosen, Erken Pliyosen - Pleistosen yaşlı birim çökelmezliği takip eden evrenin ürünüdür. Geç Miyosen ile Pliyosen arasında da uyumsuzluk görülür. kuzeyindeki linyit sahaları genellikle Istranca Masifi eteklerinde yer almakta olup, İstanbulSilivri-Sinekli; Tekirdağ-Saray-Küçük Yoncalı; Tekirdağ - Saray - Safaalan; Tekirdağ - Saray Edirköy sahaları olarak bilinir. Trakya Havzası'nın güneyindeki kömür oluşumları ise Keşan, Malkara, Uzunköprü ve Meriç sahaları ile anılır. Havzanın kuzeyinde ve güneyinde yüzeyleyen linyitler, havzanın ortasına doğru tedrici olarak derinleşmekte ve havzanın orta kesimlerinde $10.000 \mathrm{~m}$ ye ulaşan çökel istif içerisinde, 600 metreyi aşan derinliklerde

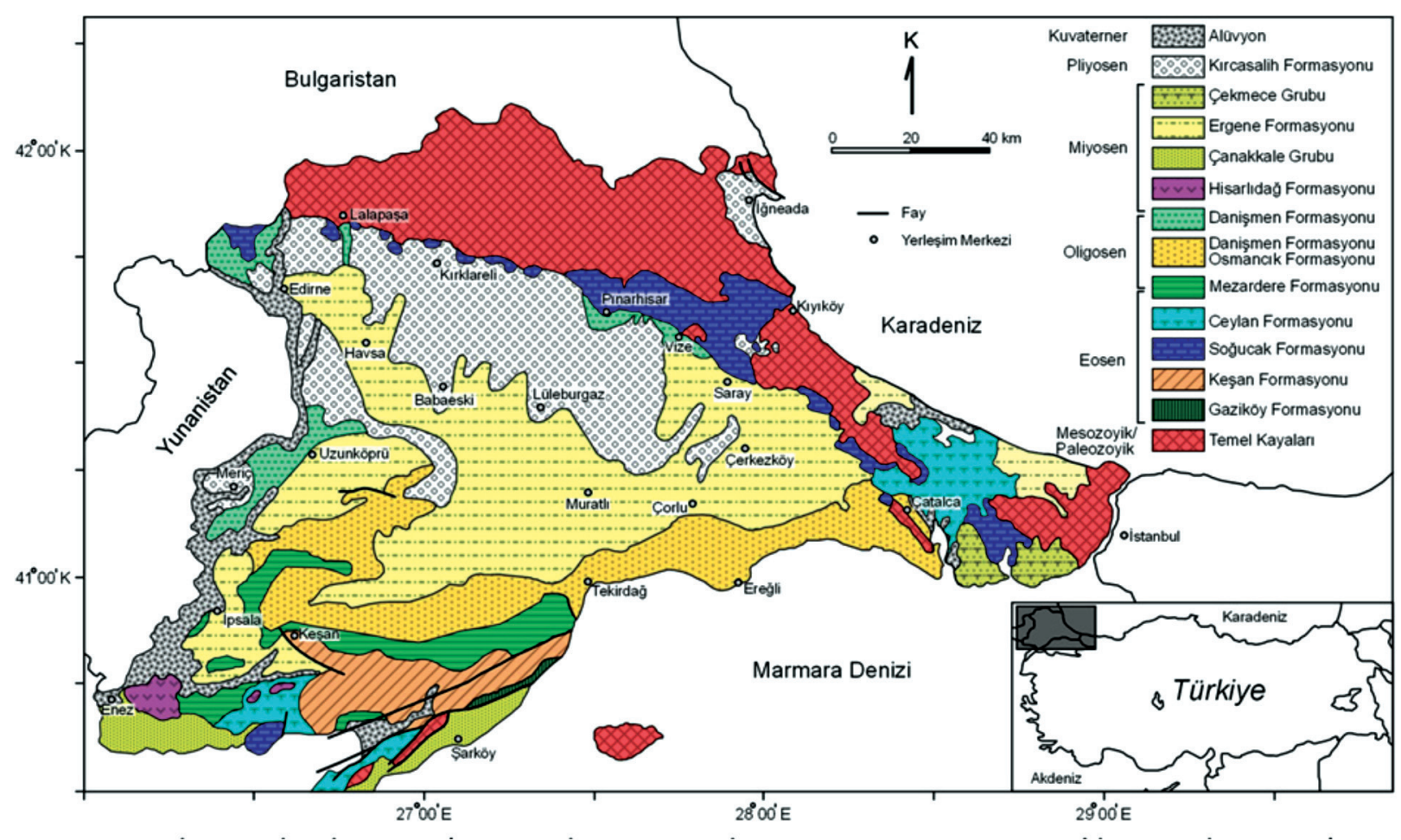

Şekil 1. Trakya Havzası'nın jeoloji haritası (Kasar ve diğ., 1983; Türkecan ve Yurtsever, 2002; Siyako, 2006 b).

Figure 1. Geological map of Thrace Basin (Kasar et al., 1983; Türkecan and Yurtsever, 2002; Siyako, 2006 b).

Havza, linyit içermesi nedeni ile yoğun jeolojik araştırmaların gerçekleştirildiği bir bölge olmuştur. Trakya Havzası'nda bu konuda yapılan başlıca çalışmalar arasında Lebküchner (1974), Kara ve dĭ̆. (1996), Şengüler ve diğ. (2000), Şengüler ve diğ. (2003), Sütçü v.d (2009), Şengüler (2008, 2013) sayılabilir. Trakya Havzası'nın yer almaktadır (Şengüler, 2013). Lebküchner (1974) tarafindan hazırlanan makalede bölgesel jeoloji yanında linyitli kumtaşı formasyonu olarak adlandırdığı birimin fosil kapsamı ve yaşını ayrıntılı olarak sunmuştur. Kara ve diğ. (1996) raporunda havzanın genel jeolojisine yer vermiş, özel bölümde ise Trakya Havzası'nda yer alan önemli kömür 
sahaları ile ilgili bilgi aktarmışlardır. Şengüler ve diğ. (2000) makalelerinde Keşan, Malkara ve Uzunköprü yöresindeki kömür işletmelerinden alınan örnekler üzerinde çalışmışlardır. $\mathrm{Bu}$ çalışmalarda özellikle işletilmekte olan damarları inceleyerek kömür çökelme ortamlarına ilişkin yorumlar getirmişlerdir. Şengüler (2008) tarafindan 2 cilt olarak hazırlanan raporda Trakya Havzası kömürlerinin yayılımı, özellikleri, çökelim modeli yanında bölgede bilinen saha ve işletmelere de yer verilmiştir. Trakya Havzası'nın kömürleri; gölsel ortamların delta bataklıklarında çökelmiştir. Çökme hızının yüksek olması çökel kalınlığının fazla olmasına neden olmuş, bu ise kömür damarlarının korelasyonunu güçleştirmiştir (Şengüler, 2013). Danişmen Formasyonu çökelimi sırasında yer yer akarsu ortam koşulları etkin olmuş, bu durum linyit çökelimini engellemiştir.

Anadolu ve Balkanlar'ın genel tektonik çatısını oluşturan ve Miyosen'den günümüze kadar gelişen yapısal hatlardan önemli bir tanesi olan Kuzey Anadolu Fayı (KAF) birçok yerbilimci tarafından detaylı olarak çalışılmıştır (Ketin, 1957; Bergougnan, 1975 ve 1976; Seymen, 1975; Fourquin, 1979; Barka, 1981; Barka ve Hancock, 1984). Kuzey Anadolu fay zonu, Kretase kenet kuşağı boyunca uzanır yada bu kuşağı birkaç kez keser (Ketin, 1976; Tokay, 1973; Canıtez, 1973; Ataman ve diğ., 1975; Tatar, 1975). Kuzey Anadolu Fayı'nın Trakya'daki en yaşlı kolu olan Trakya Fay Sistemi Kuzey Anadolu Fayı ile benzer özellikler sunmaktadır (Perinçek, 1991). Perinçek (1987, 1991) tarafından yapılan çalışmanın amacı 1) Fay sistemin geometrisini tespit etmek 2) Tektonik kökenini ilişkilerini ve kökenini irdelemek 3) Yaşını belirlemek, 4) Trakya Fay Sistemi'nin atım miktarını tartışmaktır. Sonuncu şık hariç diğerleri konusunda beklenen amaca ulaşılmıştır.

Trakya Havzasında yapılan çalışmanın amacı havzanın tümünün linyit potansiyelini ortaya çıkarmaktır. Bu hedefe ulaşmak için bölgesel ölçekli haritalar ve stratigrafik kuyu korelasyonları yapılmıştır. Toplam linyit kalınlık haritası, üretilen diğer kalınlık ve yapı haritalarıyla karşılaştırılmış, veri birlikteliği ve uyumu sağlanmış, sismik yorumlar da dikkate alınarak Trakya Havzasında linyit düzeylerine ekonomik şartlarda ulaşılabilecek alanlar saptanmıştır (Perinçek ve diğ., 2014 baskıda). Bu çalışmada ağırlıklı olarak, inceleme sırasında üretilen korelasyonlar sunulacak, bunların ve haritaların yapisal ve stratigrafik yorumu yapilacaktır.

$\mathrm{Bu}$ harita ve stratigrafik korelasyonlar sayesinde havzanın linyit potansiyeli dışında petrol aramaları içinde yararlı olacak bilgiler derlenmiş, elde edilen sonuçlarla, linyit ve petrol aramalarına katkı sağlayacak verilere ulaşılması amaçlanmıştır.

Haritalar dışında yapılan diğer önemli bir çalışma kuyular arası yapılan korelasyonlardır. Trakya Havzası'nda TKİ, MTA ve TPAO tarafindan açılan kuyu verileri dikkate alınarak stratigrafik korelasyonları gerçekleştirilmiştir. Korelasyon yapılırken bazı alanlarda TPAO tarafindan sağlanan sismik hatlarda kullanılmıştır. Bu çalışma sırasında yapılan korelasyonlar Danişmen Formasyonunun yanal fasiyes değişimlerini ve linyit katkılarının yanal kalınlık değişimlerini göstermesi nedeniyle linyit aramalarına önemli katkılar sağlamakta, yol göstermektedir. Düşey ve yatay fasiyes değişimlerini korelasyonlarda görmek mümkündür. TKİ ve MTA tarafindan farklı y1llarda açılan birbirine çok yakın kuyularda dahi farklı jeologlar tarafından farklı litoloji tanımları yapılmıştır. $\mathrm{Bu}$ durum korelasyonu güçleştirmiştir. Uzun bir zaman ayrılarak, eldeki verinin birlikteliği sağlanmaya çalışılmıştır. Bu makalede stratigrafi korelasyonları, Trakya Havzası kuzeydoğu kesimi için hazırlanan linyit kalınlık haritası ve tüm Havza için hazırlanan Ergene+Kırcasalih formasyonları toplam kalınlık haritası sunulacaktır. 


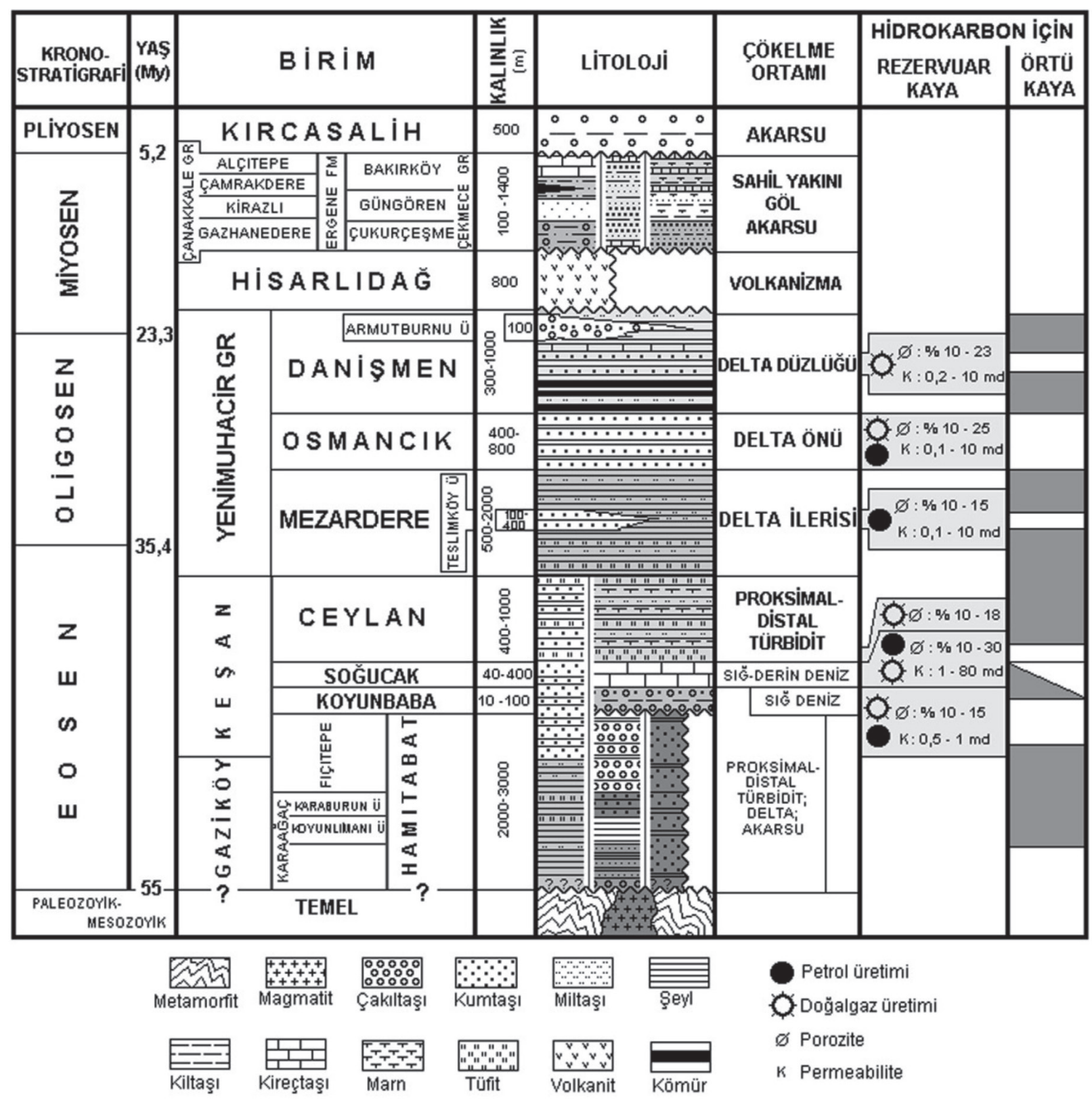

Şekil 2. Trakya Havzası Tersiyer istifinin genelleştirilmiş stratigrafik kesiti (Siyako 2006a).

Figure 2. Generalized Tertiary stratigraphic section of the Thrace Basin. 


\section{STRATIGRAFI}

Trakya Havzası'nın Alt Eosen-Orta Eosen birimleri Gelibolu Yarımadası'nda Karaağaç ve Fıçıtepe formasyonları ile temsil edilmektedir. $\mathrm{Bu}$ iki birimin Güney Trakya'daki yanal eşdeğerleri, türbiditik özellikler gösteren Gaziköy Formasyonu ve Keşan Formasyonu'nun alt seviyeleridir. Kuzey Trakya'da ise, bu dört birimle aynı zaman aralığında çökelen ve petrol kuyularında tanımlanan, mostrası olmayan, Hamitabat Formasyonu bulunmaktadır. Orta Eosen-Alt Miyosen çökelleri transgresif olarak gelişen, Koyunbaba ve Soğucak formasyonlanıdır. Havzanın giderek derinleşmesiyle Ceylan Formasyonu çökelmiştir (Şekil 1 ve 2). Ceylan Formasyonu üzerine bu birimle geçişli olan ve delta ortamında çökelen Yenimuhacir Grubu gelir (Kasar ve diğ., 1983; Saner, 1985; Sümengen ve Terlemez, 1991; Atalık, 1992; Siyako, 2005, 2006b). Delta sisteminde gelişen Yenimuhacir Grubu alttan üste doğru Mezardere, Osmancık ve Danişmen formasyonlarından oluşur (Şekil 3) (Perincek, 1987, 1991; Siyako 2006 a, b). Erken Miyosen sonunda, bölge tümüyle dolarak ve yükselerek kara haline gelmiş ve bir aşınma fazından sonra Geç Miyosen-Pliyosen yaşlı genç birimlerin sedimantasyonu başlamıştır (Şekil 1 ve 2).

Üst Miyosen birimleri Çanakkale ve Çekmece grupları ile Ergene Formasyonu olarak bilinmektedir (Siyako, 2006 b). Karatepe Bazaltı da Miyosen yaşlı bir formasyondur. Pliyosen, özellikle Kuzey Trakya'da geniş yüzlekleri olan Kircasalih Formasyonu ile temsil edilmektedir (Siyako, 2006 b). Pleyistosen çökelleri Marmara Denizi çevresinde tanımlanan denizel taraçaların oluşturduğu Marmara Formasyonu adı altında incelenmiştir.

\section{Yenimuhacir Grubu}

Yenimuhacir Grubunu oluşturan sistem delta önü ve delta düzlüğü ortamlarını temsil eden birimlerden oluşmakta olup Osmancık ve Danişmen Formasyonlarının karşılığı olarak kullanılmıştır (Siyako, 2006b).Yenimuhacir Grubu alttan üste doğru sırasıyla Mezardere, Osmancık ve Danişmen formasyonlarından oluşmuştur (Şekil 1 ve 3). Mezardere Formasyonu'nun palinolojik incelemelerine göre yaşının Geç Eosen-Erken Oligosen olduğu ve havza doğusunda Geç Oligosen'e kadar çıkabileceği belirtilmiştir (Ediger ve Alişan, 1989; Batı ve diğ., 1993, 2002).

Birim altındaki Ceylan ve Keşan formasyonları ile dereceli geçişlidir. Altta Ceylan Formasyonu'nun olmadığı paleoyükselimlerde Soğucak Formasyonu ile geçişlidir. Grubu oluşturan birimlerden Mezardere ve Osmancık formasyonlarının bulunmadığı kesimlerde ise daha yaşlı litolojiler üzerinde uyumsuzdur (Şekil 3). Birim üstten aşındırılmıştır, daha genç birimler tarafindan uyumsuz olarak örtülür.

Yenimuhacir Grubunu oluşturan formasyonlar, klasik bir delta sisteminde yanal ve düşey yönde birbirleriyle girik olan ve ayrı birimler olarak haritalanması gereken, sirasıyla delta ilerisi, delta önü ve delta düzlüğünde çökelmiş birimlerdir (Siyako, 2006b). Yenimuhacir Grubu üste doğru kabalaşan kırıntılılardan (şeyl, silttaşı, kumtaşı ve çakıltaşı) oluşur. Bu kırıntılılar aralarında tüf, kireçtaşı ve kömür katkıları içerir. Tüfitler kılavuz seviyeler olarak ayrılabilmekte ve çok uzun mesafelerde takip edilebilmektedirler. Birim içerisinde kumtaşı katkıları da sıkça gözlenir.

Yenimuhacir Grubu içerdiği palinomorf topluluğuna göre Geç Eosen-Erken Miyosen yaşındadır (Alişan, 1985; Gerhard ve Alişan, 1987; Ediger ve Alişan, 1989; Batı ve diğ., 1993; Bat1 ve diğ., 2002). 


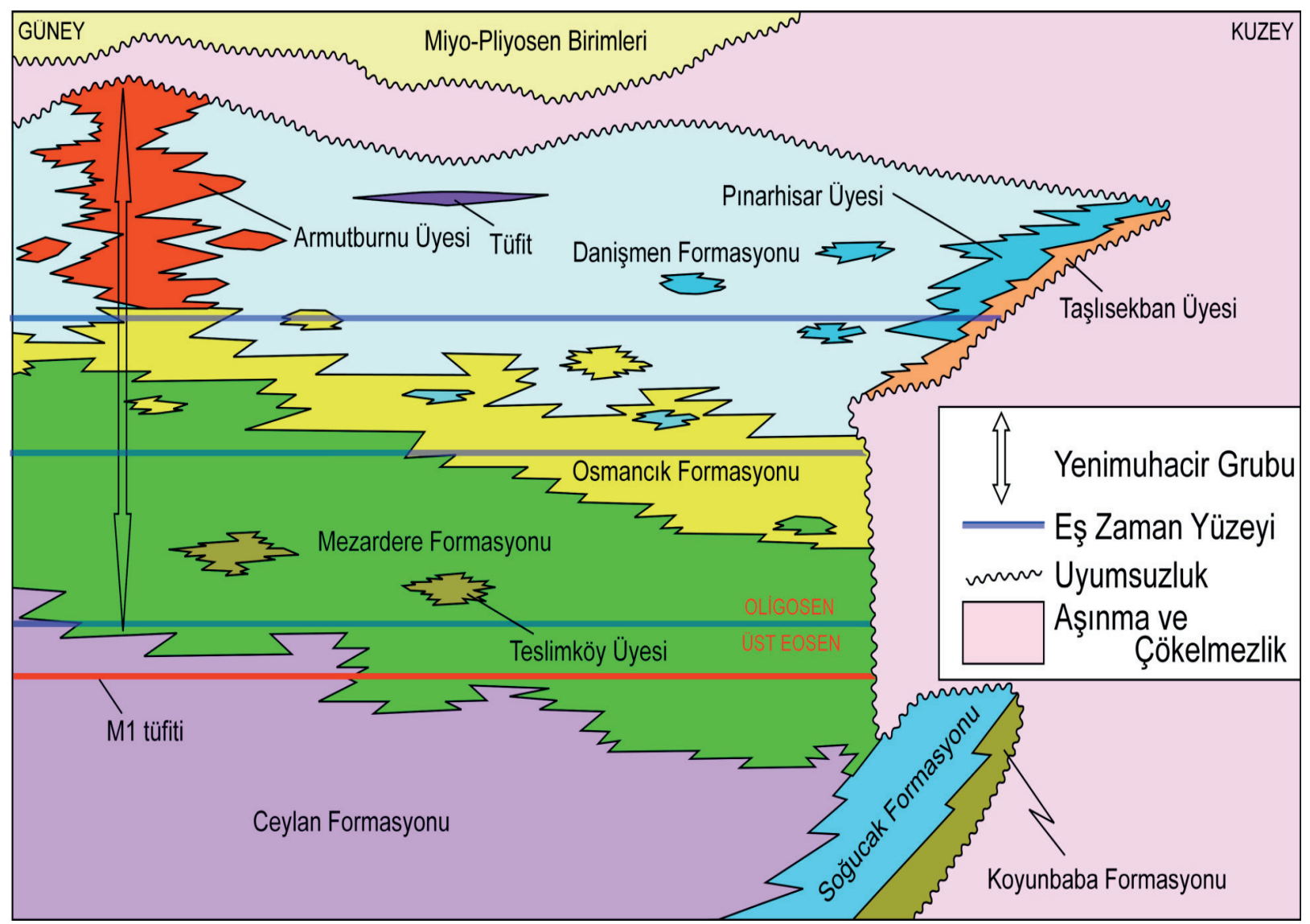

Şekil 3. Yenimuhacir Grubu birimlerinin deneştirilmesi (Siyako 2006b).

Figure 3. Correlation charts of the lithostratigraphic units of the Yenimuhacir Group.

\section{Danişmen Formasyonu Altında ve Üzerindeki Birimlerin Stratigrafisi:}

\section{Osmancik Formasyonu}

Osmancık Formasyonu altındaki Mezardere ve üstündeki Danişmen formasyonları ile çoğunlukla geçişlidir (Şekil 2 ve 3). Osmancık ve Danişmen formasyonları birçok bölgede Ergene ve Kurcasalih formasyonları tarafindan uyumsuzlukla örtülür (Şekil 1 ve 2). Osmancık Formasyonu, tane boyu üste doğru giderek irileşen, ilerleyen delta önü fasiyesinde çökelmiş regresif bir istiftir. Esas olarak kumtaş1, şeyl ve az miktarda çakıltaşı, kireçtaşı ve tüf seviyelerinden oluşmaktadır. Karasal ve denizel kökenli palinomorflara dayanarak birimin yaşının Erken-Geç Oligosen arasında değiştiği belirlenmiştir (Ediger ve Alişan, 1989; Batı ve diğ., 1993; Bat1 ve diğ., 2002; Siyako, 2006b).

\section{Danişmen Formasyonu}

Danişmen Formasyonu alttaki Osmancık Formasyonu ile dereceli geçişlidir (Şekil 2 ve 3). Danişmen Formasyonu bazı alanlarda üstten önemli oranda aşındırılmış olup, genç birimler tarafindan uyumsuz olarak örtülmektedir. Birim 
Istranca eteklerinde, Osmanckk ve Mezardere formasyonlarının olmadığ yaşlı birimler üzerinde uyumsuzdur (Şekil 1). Danişmen Formasyonu regresif delta sisteminin en üst birimidir. Göl, bataklık, taşkın ovası ve akarsu çökellerinden oluşur. Birim şeyl, kiltaşları, kumtaşı, çakıltaşı ve kömür katkıları ile temsil edilir (Şekil 4 A ve B). Kuzey Trakya'daki yüzleklerinde balık fosilleri, Güney Trakya'da ise silisifiye ağaç fosilleri yaygındır. Seyrek olarak tüf-tüfit ve kireçtaşı seviyeleri de görülür. Danişmen Formasyonu'nun yeraltında tesbit edilen kalınlığı 1000 metreye kadar çıkmaktadır (Kasar ve diğ., 1983; Siyako, 2005). Ancak, birim üstten aşındırılmış olduğu için ilk kalınlığı daha fazla olmalıdır (Siyako, 2005; 2006b). Bu çalışmada Ergene Formasyonu kalınlığının havza ortasında 1300 metreyi geçtiği saptanmıştır. Havza kenarlarına doğru kalınlık azalır. Birim Kasar ve Eren (1986), Batı ve diğ., (2002)'ne göre Geç Oligosen, Saraç (1987) Erken Oligosen, diğer araştırmacılara göre de Geç Oligosen-Erken Miyosen yaşındadır (Alişan, 1985; Gerhard ve Alişan, 1987; Batı ve diğ., 1993). Danişmen Formasyonu içinde bilhassa linyit damarlarında zengin omurgalı faunalara ait fosiller bulunur. Yapılan omurgalı fosil tanımlamalarına göre birim Oligosen'in orta kesimlerine karş1lık gelmektedir (Umut ve diğg., 1983; Umut ve diğ., 1984).

\section{Danişmen Formasyonu'nun}

alt

kesimlerinde görülen linyitli seviyelerin taban1; yapılan sondajlı arama çalışmalarında, Danişmen ile Osmancık formasyonlarının arasındaki dokanak olarak tarif edilmektedir. (Siyako, 2005, 2006b).

Danişmen Formasyonu içerisinde Taşlısekban, Pınarhisar ve Aramutburnu üyeleri ayrılmıştır (Şekil 3). Danişmen Formasyonu'nun mostra verdiği alanlarda linyit katkıları açık (Şekil 4 A) ve kapalı ocak olarak işletilmektedir.
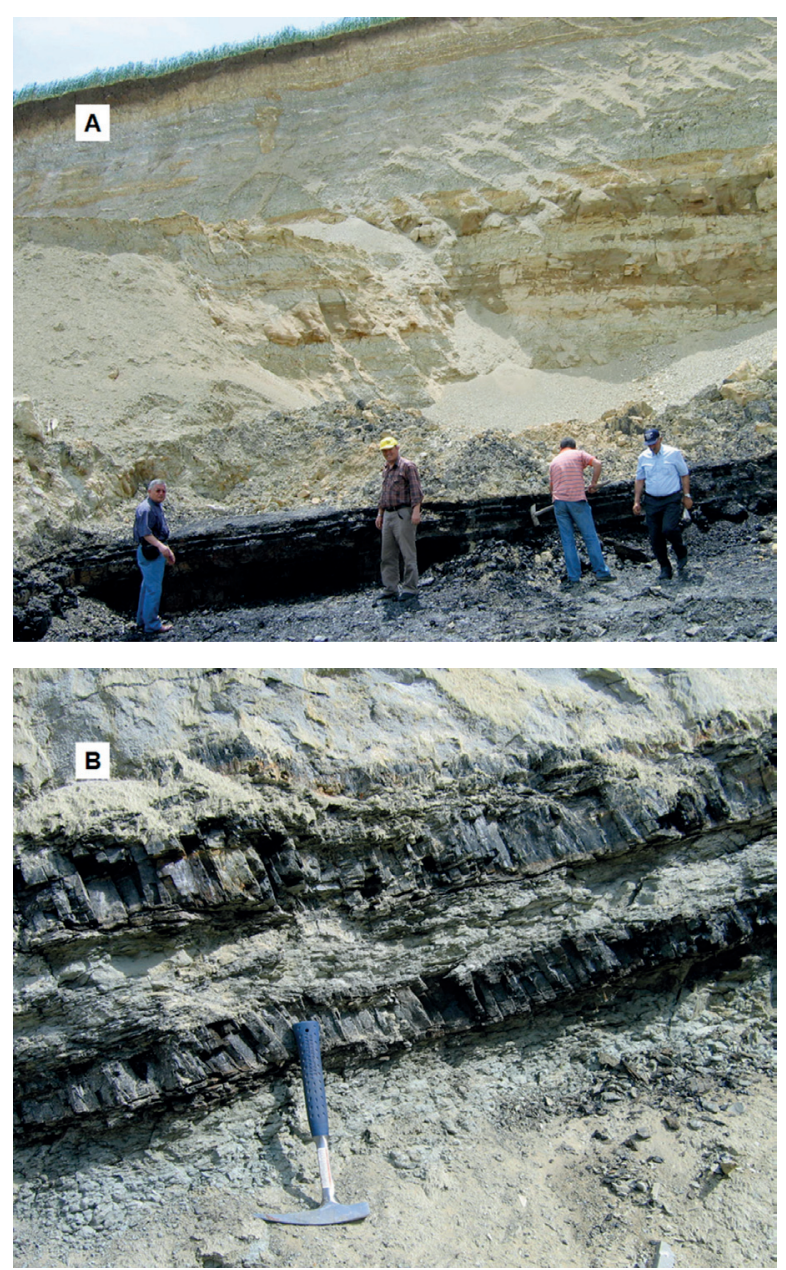

Şekil 4 Üste açık ocak işletmesinde Danişmen Formasyonu içinde yer alan linyit seviyeleri (A) ve altta marn ile ardalanan ince linyit katkıları görülmektedir (B).

Figure 4. Lignite layers at an open-pit mine in the Danişmen Formation (A) and thin lignite seams are imbedded in claystone (B).

Taşlısekban Üyesi: Birim, daha yaşlı birimler üzerinde uyumsuzdur,. Üstte Pınarhisar Üyesi'ne dereceli olarak geçer. Taşlısekban Üyesi; çakıltaş1, kumtaşı ve marndan oluşmuştur. Yer yer kiltaşı ve lamellibranş yığışımları görülür. Çatalca'daki yüzlekleri metamorfik temelden ve Soğucak Formasyonu'ndan malzeme almış, çok kaba malzemeli yamaç molozu fasiyesi ile 
başlamaktadır (Çağlayan ve Yurtsever, 1998). Taşlısekban Üyesi Pınarhisar Üyesi kireçtaşlarının taban çakıltaşını oluşturur. Birimin yaşı stratigrafik konumuna göre Oligosen'dir.

Pınarhisar Üyesi: Altta Taşlısekban Üyesi, üstte ise Danişmen Formasyonu'nun kiltaşı ve şeyl düzeyleri ile dereceli geçişlidir. Pınarhisar Üyesi, sı ̆ denizel, lagüner, kumtaşı ve çakıltaşı katkıl1, oolitli, bol lamellibranş, gastropod ve ostrakodlu, üst seviyelerinde manganlı seviyeler bulunduran ve yer yer killi olan kireçtaşı ile temsil olunur. Birimin tip kesitinde kalınlığ 70-80 metre ölçülmüştür (Kasar ve Eren 1986). Ortalama kalınlığı 5-20 metre arasında değişir. Birimin yaşının Erken Oligosen (Gökçen, 1971; Kasar ve Eren, 1986), Oligosen (Umut ve diğ., 1983, 1984) olduğu belirtilmiştir.

Armutburnu Üyesi: Siyako (2006b) birimin yayılımı, kalınlığı ve Danişmen Formasyonu ile olan stratigrafik ilişkisini dikkate alarak birimi Danişmen Formasyonu'nun bir üyesi olarak belirtmiştir. Armutburnu Üyesi tip kesitinde, hem alttaki Osmancık Formasyonu hem de Danişmen Formasyonu ile yanal ve düşey geçişlidir (Şekil 3). Birim, üzerine gelen daha genç litolojiler tarafından açısal uyumsuzlukla örtülür. Delta düzlüğü çökelleri kırmızı renkli, kalın tabakal1-masif, genellikle akarsu kanal dolgusu çakıltaşı ve kumtaşı ile temsil edilir. Ender olarak taşkın ovası çamurtaşı ve seyrek olarak kömür seviyelerinden oluşur. Kalınlığı ortalama 100 metre dolayındadır (Temel ve Çiftçi, 2002). Armutburnu Üyesi, Gelibolu'da Geç Oligosen (Temel ve Çiftçi, 2002), Batı Trakya'da Oligosen olarak (Umut ve diğ., 1984) yaşlandırılmıştır. N.V.Turkse Shell (1969) tarafından verilen Miyosen yaşı da dikkate alındığında birim için Oligo-Miyosen yaşı kabul edilmiştir (Siyako, 2006b).

\section{Ergene Formasyonu}

Ergene Formasyonu adlaması ilk defa Boer (1954) tarafından kullanılmıştır. Ganosdağ-KorudağHisarlıdağ yükseliminin kuzeyinde kalan Miyosen sedimanter birimleri Ergene Formasyonu kapsamına alınmış, içerisinde Çelebi ve Sinanlı üyeleri ayrılmıştır (Şekil 1 ve 5).

Kasar ve diğ., (1983), Turgut ve di ̆. ., (1983) ve Perinçek (1991) çalışmalarında Ergene Formasyonu'nu Kircasalih Formasyonu ile birlikte, Ergene Grubu adı altında incelemişlerdir.
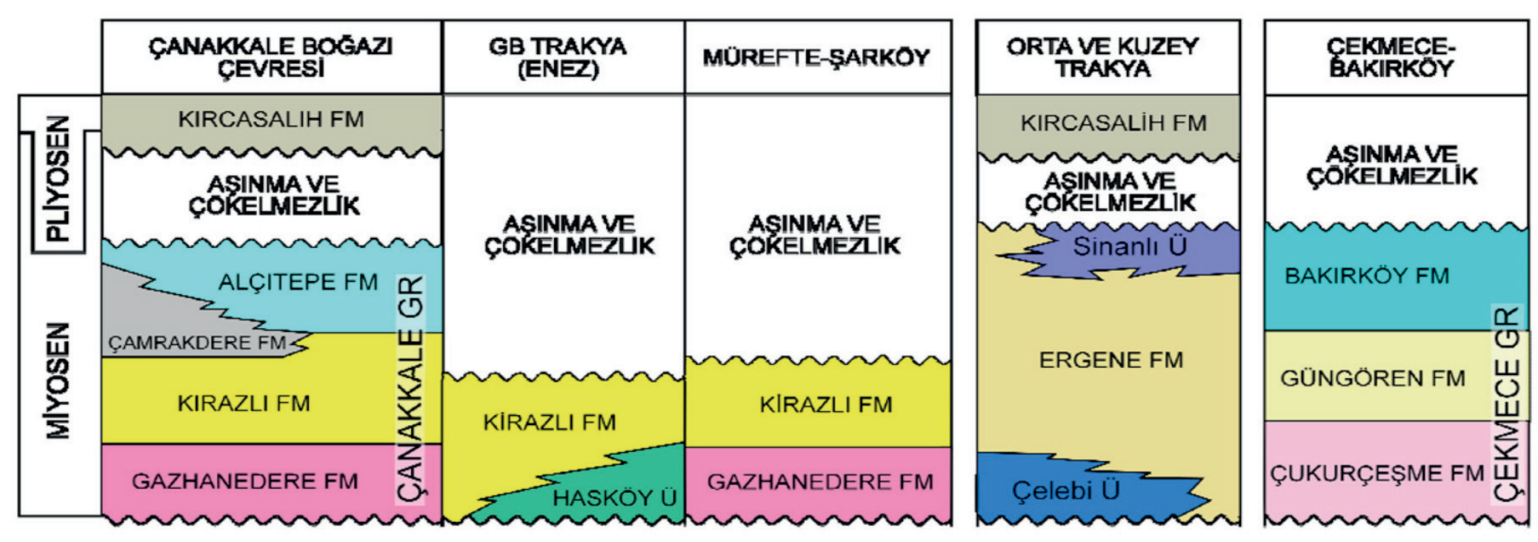

Şekil 5 Gelibolu Yarımadası ve Trakya'da Miyosen birimlerinin deneştirilmesi (Siyako 2006b).

Figure 5. Correlation charts of Miocene units of the Thrace Basin and Gallipoli Peninsula (Siyako 2006b). 
Ergene Formasyonu, daha yaşlı birimlerle ve üzerine gelen Kircasalih Formasyonu ile dokanağ1 uyumsuzdur (Şekil 2 ve 3). Ergene Formasyonu, akarsu ve göl ortamı ürünü, çapraz tabakalı çakıltaşı ve kumtaşı ile, bol bitki ve omurgalı fosili içeren kumtaşı, miltaşı ve kiltaşı litolojilerinden oluşur (Siyako, 2006b). Ergene Formasyonu kalınlığını havza kenarlarında 0-60 metre, havza ortalarında ise 800-1200 metre dolayındadır (Siyako, 2006b; Perinçek 2010a, 2010 b ve 2010c, Perinçek ve diğ., 2014 baskıda). Perinçek (1987) Ergene Grubu için (Ergene Formasyonu ve Kircasalih Formasyonu birlikte) Üst Miyosen-Pliyosen yaş aralığını benimsemiştir. Ergene Formasyonu'nun yaşını Umut ve diğ., (1983), Çağlayan ve Yurtsever (1998) ve Duman ve diğ., Orta-Geç Miyosen, Umut (1988b) ve İmik (1988) Geç Miyosen olarak belirtmiştir. Birim Trakya'nın ortasında, geniş bir alanda mostra verir.

Çelebi Üyesi: Birim ilk kez Boer (1954) tarafından Çelebi Formasyonu olarak adlandırılmış, Siyako (2006b) çalışmasında bu birimi Ergene Formasyonu'nun bir üyesi olarak kabul etmiştir (Şekil 5). Çelebi Üyesi, altındaki Danişmen Formasyonu'nun Armutburnu Üyesi ile açı1ı uyumsuzdur (Umut ve diğ., 1984). Çelebi Üyesi'nin klastikleri tabanında yer aldığı Ergene Formasyonu ile yanal ve düşey yönde geçişlidir (İmik, 1988). Birim, Uzunköprü güneyinde beyaz, gri, yeşilimsi renkli gölsel kireçtaşından oluşur. Yatay, ince-orta tabakalı kireçtaşı katmanları seyrek kil ve kumtaşı katkılıdır (Umut ve diğ., 1984; Umut, 1988a; İmik, 1988). Birimin kalınlığ1 40 metre dolayındadır. Çelebi Üyesi yanal ve düşey yönde geçişli olduğu Ergene Formasyonu gibi Orta-Geç Miyosen yaşında olduğu kabul edilmiştir (Siyako, 2006b).

Sinanlı Üyesi: Birim ilk kez Umut ve dĭg., (1983) tarafindan formasyon mertebesinde tanımlanmış, Siyako (2006b) ise Ergene Formasyonu'nun bir üyesi olarak kabul etmiştir. Birim, Ergene Formasyonu üzerine uyumlu ve yanal geçişlidir (Şekil 5). Üzerindeki Kırcasalih Formasyonu tarafindan uyumsuzlukla örtülür (Umut ve diğ., 1983). Sinanlı Üyesi akarsu ve göl ortamında çökelmiştir. Altta Kaliçili ve yumrulu kireçtaşı seviyeleri ile başlar, üstte masif görünümlü yer yer killi, kumtaşı ve kiltaşı katkılı kireçtaş1 düzeylerinden oluşur (Umut ve diğ., 1983; Çağlayan ve Yurtsever, 1998). Sinanlı Üyesi yanal yönde geçişli olduğu Ergene Formasyonu gibi Orta-Geç Miyosen yaşındadır.

\section{Çanakkale Grubu}

$\mathrm{Bu}$ birimin adlanması ilk defa formasyon mertebesinde yapılmış (Şentürk ve Karaköse, 1987), Siyako (2006a) tarafından grup aşamasına çıkartılmıştır. Çanakkale Grubu kapsamında, Ganosdağ-Korudağ-Hisarlıdağ yükseliminin güneyinde yer alan Geç Miyosen yaşıı birimler bulunmaktadır (Şekil 1 ve 2). Çanakkale Grubu Ergene Formasyonu'nun farklı ortamda çökelmiş yanal eşdeğeridir (Şekil 5).

Çanakkale Grubu, güney Trakya'da, Çanakkale Boğazı'nın her iki yakasında, Gökçeada ve Bozcaada'da Gazhanedere, Kirazlı, Çamrakdere ve Alçıtepe formasyonlarına ayrılmıştır. Orta ve kuzey Trakya ile Haliç ve Büyükçekmece Gölü arasında yer alan Miyosen Çekmece Grubu'nun Çanakkale Grubu ile doğrudan bağlantısı bulunmamaktadır (Siyako 2006b). Üç istifin litolojisi de tam bir benzerlik taşımaz. Bu nedenle orta-kuzey Trakya'da ve İstanbul batısında yüzlek veren birimler Çanakkale Grubu'ndan ayrı tutulmuş; Ergene Formasyonu ve Çekmece Grubu olarak isimlendirilmiştir (Şekil 5). Çanakkale Grubu altındaki ve üstündeki birimlerle uyumsuz olup, başlıca kumtaş1, çakıltaşı, kiltaş1, çamurtaş1 
ve seyrek olarak sı̆̆ denizel, lagüner kireçtaşından oluşur. Birimin toplam kalınlığ1 800-1400 m arasında değişir, yaşı ise Orta-Geç Miyosen'dir (Siyako 2006b).

\section{Kırcasalih (Trakya) Formasyonu}

Kircasalih Formasyonu'nu ilk kez Boer (1954)'in adlandırdığını belirterek Ünal (1967) kullanmıştır. Kasar ve diğ., (1983) tarafından tanımlanan Ergene Grubu'nun üst kesimleri de Kırcasalih Formasyonu'na karşılık gelir. Umut ve diğ., (1984), Umut (1988 a, b), İmik (1988) ve Çağlayan ve Yurtsever (1998) birim için Trakya Formasyonu adlamasını kullanmışlardır.
Kircasalih Formasyonu, Trakya'daki hemen hemen daha yaşlı tüm birimler üzerine uyumsuz olarak gelmektedir (Şekil 1) (İmik, 1988; Siyako, 2006b). Birim, tutturulmamış çakıl, kaba taneli çakıltaşı ile kumtaşı ve seyrek kiltaşından oluşur (Şekil 2). Çakıllar genellikle kuvars, kuvarsit, nadiren şist, metagranit ve volkanit türü kayalardan oluşmuştur. Birim akarsu ortamında çökelmiştir. Birimin kalınlığının, sismik kesitler ve kuyu verilerine göre 500 metreye kadar ulaşabileceği belirtilmiştir (Siyako, 2006b). Kırcasalih Formasyonu'nun yaşı Çağlayan ve Yurtsever (1998)'e göre en Geç MiyosenPliyosen, stratigrafik konumu dikkate alındığında ise Pliyosen' dir.

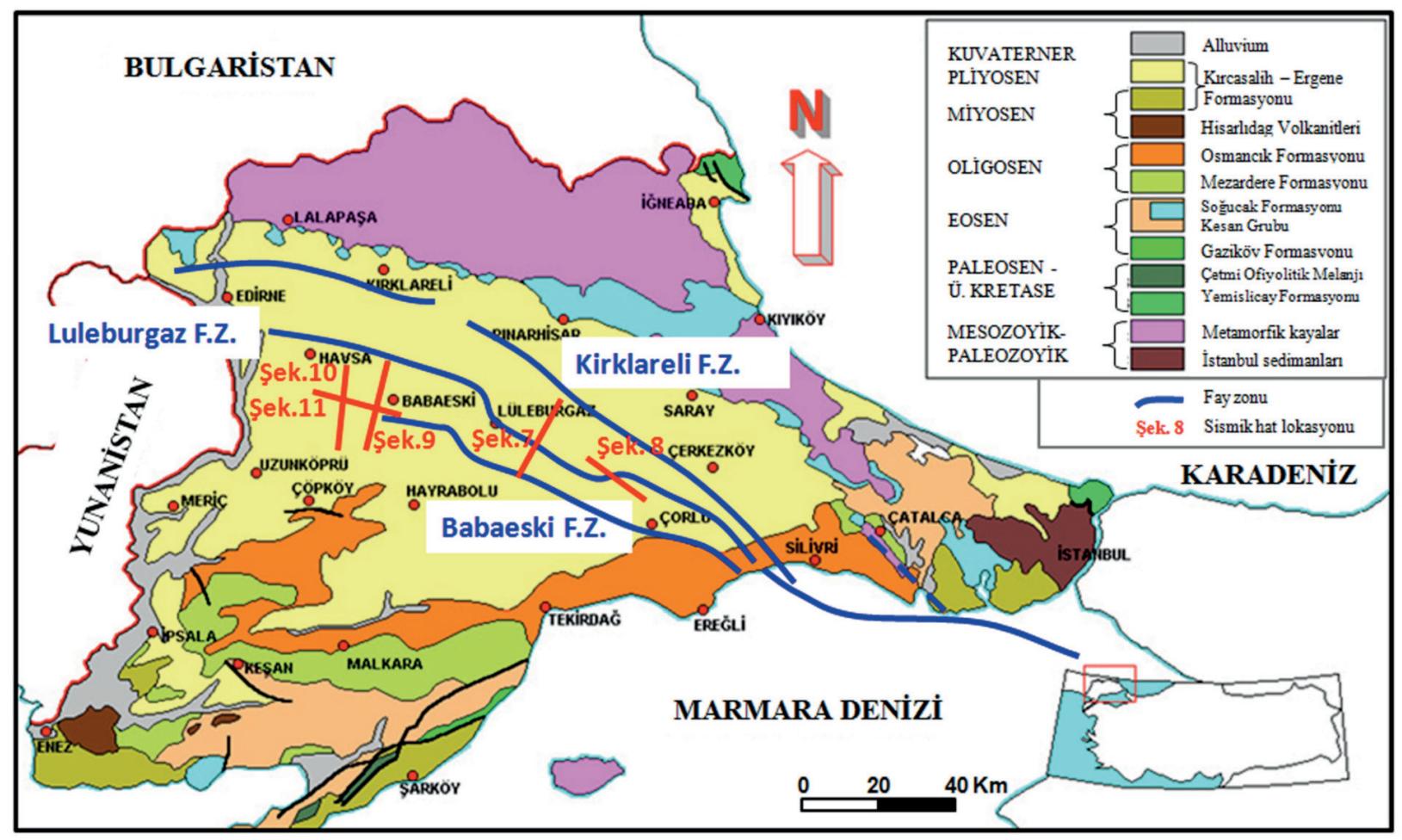

Şekil 6. Trakya Havzası jeoloji Haritası ve Trakya Fay zonları (Kasar ve diğ., 1983; Perincek 1991; Perinçek 2006 sadeleştirilerek alınmıştır). Trakya Fay Sistemi; Geç Miyosen Pliyosen istifi altında gömülüdür.

Figure 6. Geology map of the Thrace Basin and Thrace Fault System (Kasar et al., 1983; Perincek 1991; and simplified fault map from Perinçek 2006). 


\section{YAPISAL JEOLOJI்}

Perinçek (1987, 1991) tarafindan Trakya Fay Sistemi olarak tanımlanan yapısal hatların Ergene Formasyonu'nun çökelmesi öncesinde oluştuğu ve sağ yanal atımlı olduğu bilinmektedir. Perinçek (1991) sismik veriler ile yaptığı çalışmasında Trakya Havzası'nda Kuzey Anadolu Fayının Geç Miyosen öncesinde Trakya Havzası'nda aktif olduğu belirtilmiştir. Söz konusu fay zonu kuzeydoğudan güneybatıya Kırklareli, Babaeski ve Lüleburgaz Fay Zonu olarak adlandırılmıştır (Şekil 6). Söz konusu fay sistemi Orta Miyosen sonu - Geç Miyosen başlarında Geç OligosenErken Miyosen yaşlı Danişmen Formasyonu'nun çökelimini takiben aktif olmuş yanal atımlı bu fay sistemiyle ilgili olarak an-eşhelon yapılar gelişmiştir. Bu yapıların eksenleri ve çoğu yerde fay zonları boyunca önemli miktarda aşınma gerçekleşmiştir. Bu aşınmaya bağlı olarak havzanın bazı kesimlerinde Danişmen Formasyonu kısmen veya tamamıyla aşındırılmıştır (Perinçek,2010a, 2010b, 2010c). Aşınma sonrası çökelen Geç Miyosen yaşlı Ergene Formasyonu'nun bazı alanlarda (Hamitabat Sahası) doğrudan Osmancık Formasyonu üzerine çökeldiği görülür. Faylanmaya bağl1 olarak gelişen yükselim alanlarında Danişmen Formasyonu'nun aşınmış olması dışında bu alanlar yapısal yüksekliklerini korudukları için bu yükselimler üzerinde Ergene Formasyonu daha ince olarak çökelmiştir. Çukur alanlardaki senklinallerde ise Ergene Formasyonu daha kalındır. Ergene Formasyonu çökeldikten sonra da söz konusu fayların hareketi devam etmiş (Perinçek, 1991, 2006; Perinçek ve Karslıŏlu, 2007) ve havzanın doğusundaki bazı alanlarda Ergene Formasyonu'nun tabanındaki diskordans düzlemi kıvrımlanmıştır (Perinçek, 1987, 1991).

\section{SİSMIK VERİ DEĞERLENDİIILMESI}

Şekil 7 de Lüleburgaz Fay Zonu boyunca gelişen yükselme nedeniyle solda görülen antiklinal oluşmuş, yapılaşmayı takiben yükselme sonrası antiklinal ekseni boyunca aşınma gerçekleşmiştir. Fayın oluşumundan sonra oluşan diskordans düzlemi daha sonra kıvrımlanmamıştır. Bu durum fayın bu alanda Ergene Formasyonu çökelimi sonrası hareketetmediğini gösterir(Perinçek, 1991, 2006). Şekil 7 de verilen sismik kesitte (Perinçek, 1991) sar1 ile gösterilen reflektörün, Danişmen Formasyonu'nun tabanına yakın bir düzeyi temsil ettiği, aynı kesitte turuncu ile gösterilen iki ayrı seviyenin de linyit katkıları olduğu öngörülmüştür. Sismik kesit (Şekil 7) verileri, havzada gözlenen aşınma miktarını net olarak açıklamaktadır. Daha yukarıda kırmızı ile gösterilen reflektör ise Ergene Formasyonu tabanındaki açısal uyumsuzluktur. Kesit üzerinde ortada Lüleburgaz Fay Zonu (LFZ) görülmektedir. $\mathrm{Bu}$ fayın sol tarafında görülen antiklinalin yaşı fay zonunun oluşumu ile aynıdır ve antiklinal, fayın aktivitesine bağlı olarak oluşmuştur. Antiklinalin oluşumunu takiben yaşanan erozyon sismik kesitte çok belirgindir. B ile işaretli varsayılan kuyuda Ergene Formasyonu kesildikten sonra diskordansın altında çok ince olan Danişmen Formasyonu'nun kesileceği sismik kesitte net olarak görülmektedir. B noktasında Danişmen Formasyonu'nun üst kısmının tümü aşındırılırken birim içindeki 2 adet turuncu çizgi ile varsayılarak işaretlenen linyit katkıları da aşındırılmıştır. Bu nedenle varsayılan B kuyusunda linyit kesilmeyecektir. B kuyusunun solunda, varsayılan A kuyusunda ise linyit kesilme olasılığı fazladır. Varsayılan C kuyusunda da, Danişmen Formasyonu önemli oranda aşındırıldı ğ için linyit katkısı kesilmeyeceği yorumu yapılabilir. 


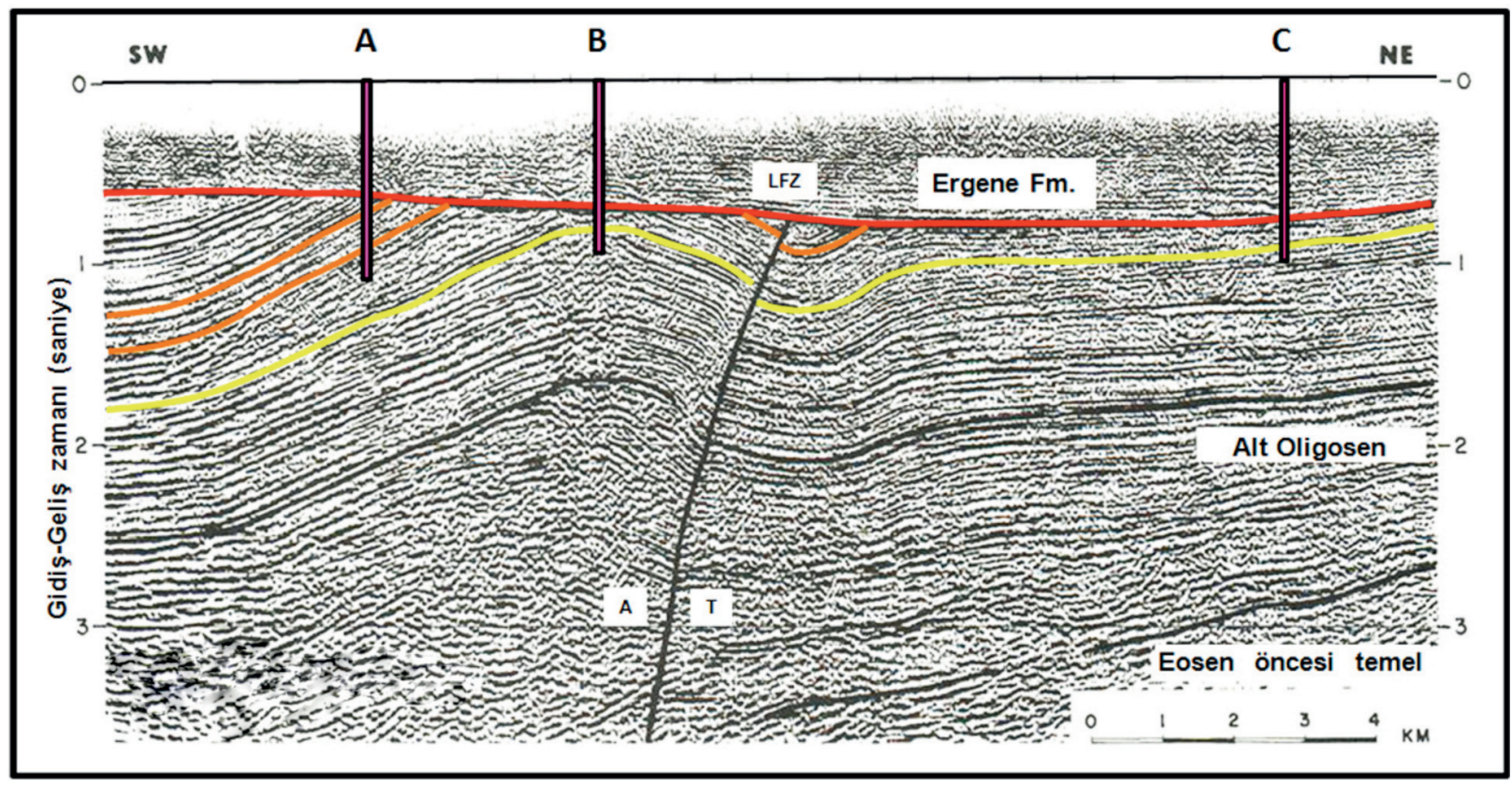

Şekil 7. Sismik kesit ortasında Lüleburgaz Fay Zonu (LFZ) görülmektedir (Lokasyon için Şekil 6'ya bakınız). Fayın sağ tarafi (T) okuyucuya doğru, sol taraf ise (A) okuyucudan uzaklaşacak şekilde hareket etmektedir (Perinçek, 1991, Şekil 10).

Figure 7. Lüleburgaz Fault Zone is seen in the middle of the seismic section (see Figure 6 for location). T= displacement toward viewer, A= displacement away from viewer (Perinçek, 1991, Şekil 10).

Şekil 8'degörülençiçekyapısı, Lüleburgaz Fay Zonu (LFZ) boyunca sıkışma büklümünde gelişmiştir. Fayın ilk oluşumunu takiben Orta-Geç Miyosen yaşl1 Ergene Formasyonu çökelmiş, bu birimin tabanındaki diskordans kıvrılmış, ardından Pliyosen yaşlı Kırcasalih Formasyonu çökelmiştir. Takip eden evrede Pliyosen istifinin tabanını oluşturan diskordans düzlemi, fay sisteminin oluşmasına neden olan sıkışma ve makaslama kuvvetlerinin aktivitesini sürdürmesi nedeniyle kıvrımlanmıştır (Perinçek, 1991, 2006). Şekil 8 de verilen sismik kesitte sarı ile işaretlenmiş seviyenin Danişmen Formasyonu'nun tabanına yakın reflektörü temsil ettiği varsayılmıştır. Kesitin sağındaki 2 adet turuncu renkle işaretli reflektör ise öngörülen linyit düzeylerini temsil etmektedir. Sismik kesitte Orta Geç Miyosen yaşlı Ergene Formasyonu tabanındaki açısal uyumsuzluk kırmızı renk ile işaretlenmiştir. Şekil 7 de söz konusu uyumsuzluk düzlemi kıvrımlanmamış olmasına karşın, Şekil 8 deki sismik kesitte kırmızı ile gösterilen diskordans düzleminin kıvrımlanmış olduğu görülür. Diskordans düzleminin kıvrımlanması havzanın batısında pek görülmemekle birlikte doğu kesiminde, Silivri yakınlarında izlenir ve Ergene Formasyonu'nun çökelmesini takiben fayın tekrar aktivite geçirdiğini böylece de diskordans düzlemini kıvırdığ1 gözlenmiştir (Perinçek, 1991, 2006). Şekil 8'nin ortasında görülen pozitif çiçek yapısı havzadaki doğrultu yanal atımlı fay sisteminin sıkışma büklümü ile ilgilidir. Sismik kesiti, linyit seviyelerin varlığını ve konumunu bulmak için değerlendirdiğimizde D kuyusunda ince bir Ergene Formasyonu'nu takiben doğrudan Osmancık Formasyonu'na girileceği öngörülmektedir. Bu 
durumda varsayılan D kuyusunda Danişmen Formasyonu'nun tümüyle aşınma olasılı̆̆ı söz konusudur. Şekil 8'de gösterilen E kuyusunda Ergene Formasyonu'ndan sonra diskordans1 takiben Danişmen Formasyonu'nun alt bölümü kesileceği düşünülmektedir. Dolayısıyla E kuyusunda aşınma nedeniyle linyit düzeylerinin kesilmesi beklenmemektedir. Varsayılan F kuyusunda ise Ergene Formasyonu kesildikten sonra diskordansı takiben linyit katkı1ı Danişmen Formasyonu'na girileceği öngörülmektedir. F kuyusundan sağa doğru gidildiğinde linyit katkıları üzerindeki Danişmen Formasyonu'na ait istifin kalınlığı artacaktır. Üstteki Ergene Formasyonu'nun kalınlığı dikkate alındığında kesitin sağ kısmında ekonomik derinliklerde linyit seviyelerine ulaşmak güçleşmektedir (Perinçek, 2010a, 2010b, 2010c; Perinçek ve diğ., 2011).
Çalışma alanındaki sismik kesitler değerlendirilmiş, olası linyit katkılarının yüzeye yaklaştığı yerler saptanmaya çalışılmıştır (Perinçek, 2010a, 2010b, 2010c; Perinçek ve diğ., 2011, Perinçek ve diğ., 2014 baskıda). Söz konusu sismik verilerin yorumları Pehlivanköy güneyi ve Karacaoğlan Beldesi yakınındaki ruhsatlar arasında kalan alan (Babaeski dolayları) için yapılmıştır. Bu makaleye MAD-84-411 (Şekil 9), MAD-84-432 (Şekil 10), MAD-84-413 (Şekil 11) numaralı sismik kesitler eklenmiştir. Babaeski 2, Minnetler 1 kuyularının verileri, sismik zaman verileri kullanılarak sismik kesitler üzerine aktarılmıştır. Kesitlerde koyu sarı renk ile gösterilen refleksiyon düzlemi Ergene Formasyonu tabanını (Danişmen Formasyonu üstü) temsil etmektedir. Kesitlerde yeşil renk ile gösterilen düzeyler olasılı linyit katkılarıdır. Yeşil ile

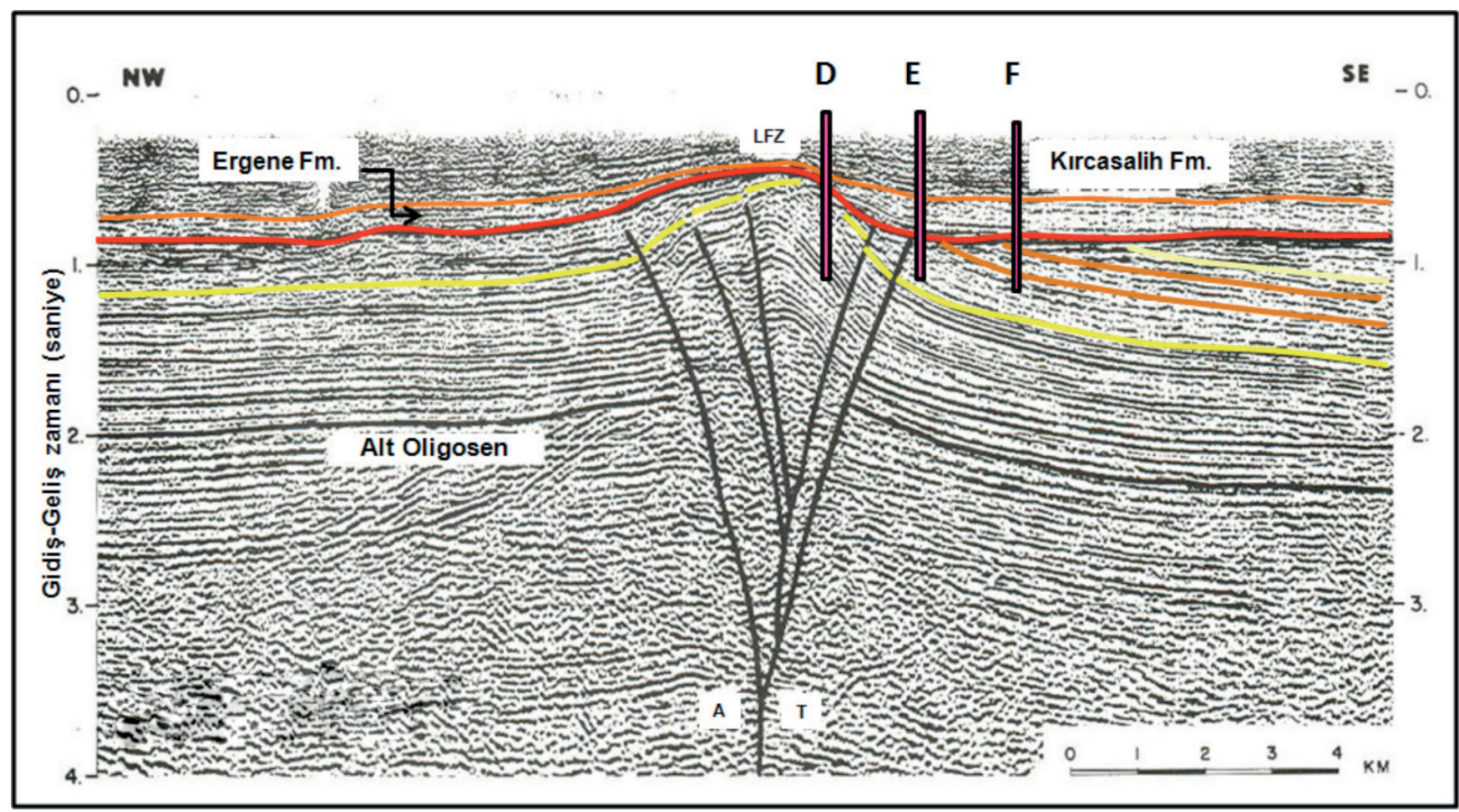

Şekil 8. Sismik kesitte Lüleburgaz Fay Zonu (LFZ) gözlenmektedir (Lokasyon için Şekil 6'ya bakınız). Fayın sağ tarafı (T) okuyucuya doğru, sol taraf ise (A) okuyucudan uzaklaşacak şekilde hareket etmektedir (Perinçek, 1991, Şekil 11).

Figure 8. Seismic section across Lüleburgaz Fault Zone (see Figure 6 for location). $T=$ displacement toward viewer, $A=$ displacement away from viewer (Perinçek, 1991, Şekil 10). 
gösterilen refleksiyon düzlemleri kuyu yakınında linyit içerebilir fakat yanal doğrultuda yeşil refleksiyonun devam etmesi sismik hat boyunca linyit katkısı bulunduğu anlamına gelmemektedir. Diğer bir deyişle yeşil ile gösterilen ve kuyularda linyitle temsil edilen düzeyler yanal yönde fasiyes değişimi gösterip marn veya kile dönüşebilir. $\mathrm{Bu}$ kesitlerde linyit katkıları içerebilecek düzlemlerin takibi yapılmış ve bunların nerelerde yüzeye yakın oldukları tespit edilmiştir. Eğer yanal yönde fasiyes değişimi yoksa yeşil düzeylerin yüzeye yakın yerlerde kesilmesi ve bunların linyit içermesi olasılığı yüksektir. Sismik kesitlerde kırmızı renk ile gösterilen çizgiler fayları temsil etmektedir.
TPAO kuyularının (Minnetler 1, Babaeski 2) sismik kesit üzerindeki yerleri düşey siyah çizgi ile gösterilmiştir. Sismik kesit üzerine düşen ve ilk aşamada açması önerilen kuyuların yeri ise sismik kesit üzerinde düşey mavi çizgi ile işaretlidir.

Şekil 9'de Minnetler 1 kuyusundan GB ve KD yönünde gidildiğinde linyit içerdiği düşünülen refleksiyonun yüzeye yaklaştığı görülür. Kesitin GB'sında P1 kuyusu önerilmektedir. Şekil 9'un Kuzeydoğusunda gösterilen P3 kuyusu sismik veriler kullanılarak önerilen diğer kuyu yeridir. Şekil 10'da sismik kesitin GB'sında P2 ile işaretli nokta Pehlivanköy dolayındadır. Bu kuyunun da bu çalışma sonrasında açılması önerilmiştir.

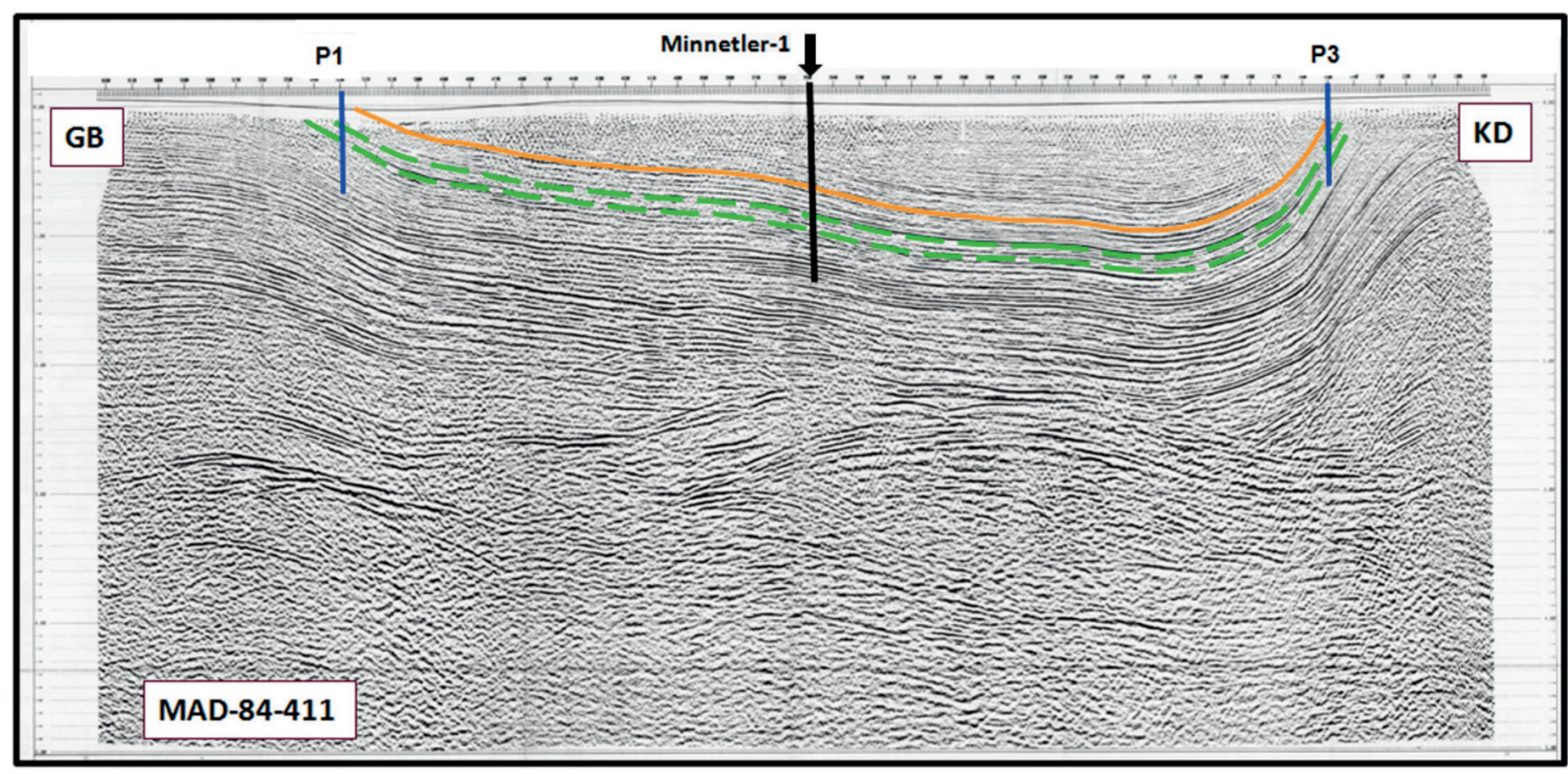

Şekil 9. Kesit üzerinde linyit katkıları (yeşil) ve Ergene Formasyonu'nun (turuncu) tabanı (Danişmen Formasyonu üstii) işaretlenmiştir. (Lokasyon için Şekil 6'ya bakınız).

Figure 9. Seismic line showing lignite layers (green) and base (orange) of the Ergene Formation (or top of the Danişmen Formation). (see Figure 6 for location). 


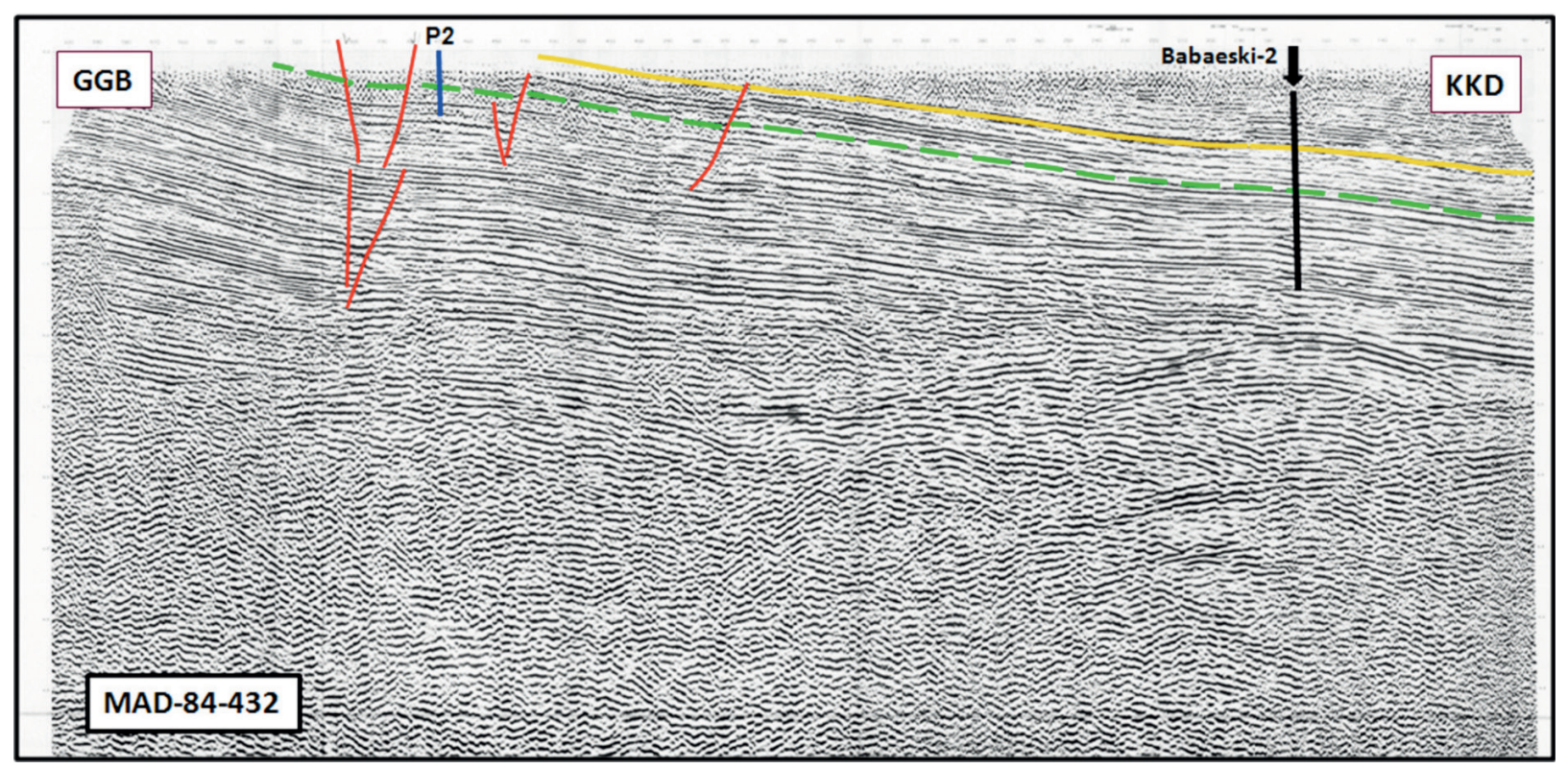

Şekil 10. Kesit üzerinde linyit katkıları (yeşil) ve Ergene Formasyonu'nun (turuncu) tabanı (Danişmen Formasyonu üstü) işaretlenmiştir. P2 kuyusu kesitin Güney-Güneybatısında kalır. (Lokasyon için Şekil 6'ya bakınız).

Figure 10. Seismic line showing lignite layers (green) and base (orange) of the Ergene Formation (or top of the Danişmen Formation). P2 well is located in the south-southwest. (see Figure 6 for location).

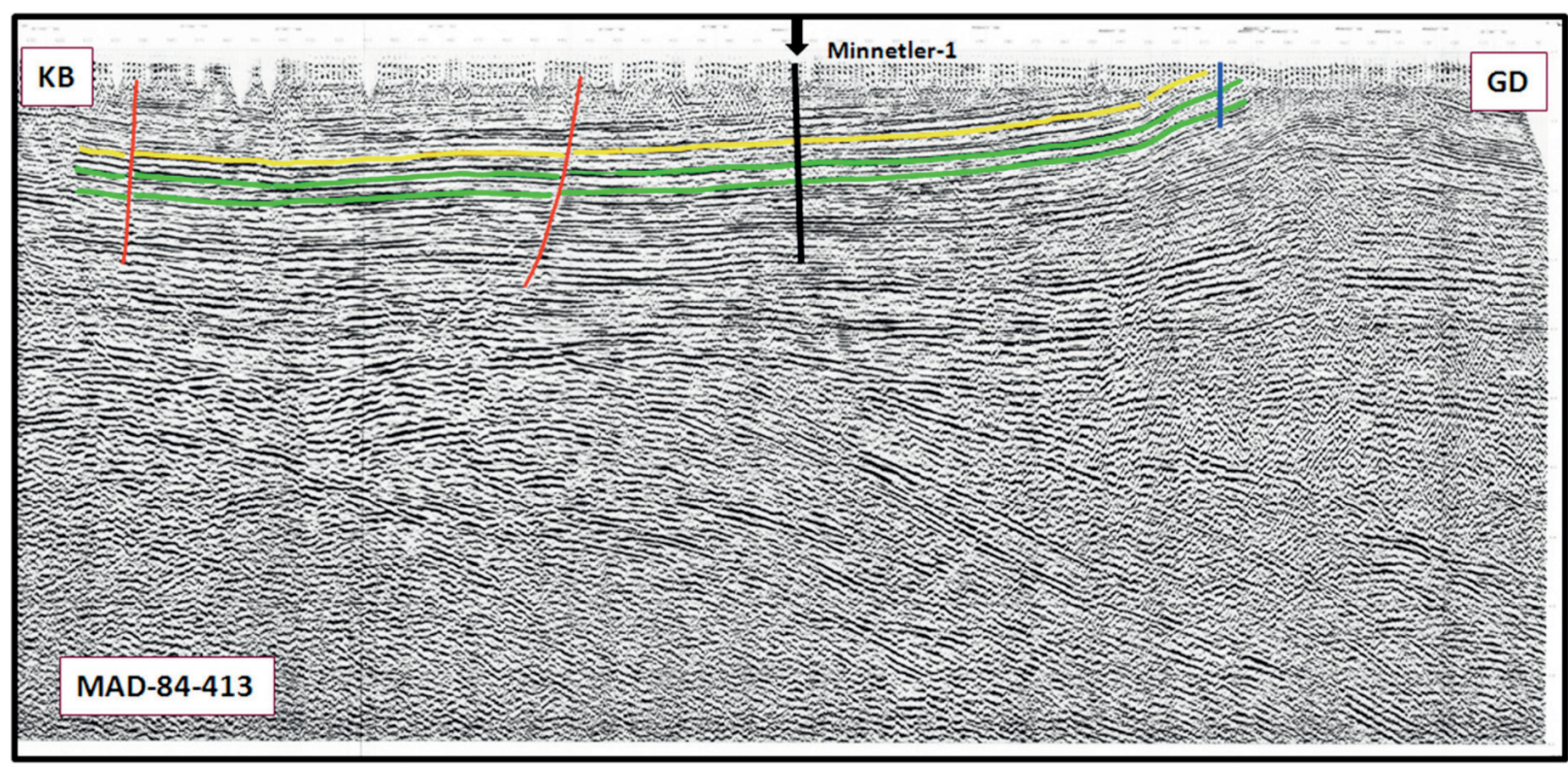

Şekil 11. Kesit üzerinde linyit katkıları (yeşil) ve Ergene Formasyonu'nun (turuncu) tabanı (Danişmen Formasyonu üstï) işaretlenmiştir. (Lokasyon için Şekil 6'ya bakınız).

Figure 11. Seismic line showing lignite layers (green) and base (orange) of the Ergene Formation (or top of the Danişmen Formation). (see Figure 6 for location). 


\section{ÜRETILLEN KALINLIK HARITALARI VE KUYU KORELASYONLARININ AMACI, YORUMU VE EKONOMIK KATKISI}

Trakya Havzası'nda linyit aramaları genellikle havzanın kuzeydoğu kenarında, güneybatısında ve güneyinde linyit katkılarının çoğunlukla mostra verdiği alanlarda ve yakınında yürütülmüştür. $\mathrm{Bu}$ çalışmanın bulguları kullanılarak havza için yepyeni bir arama stratejisi oluşturulmuştur (Perinçek, 2010a, 2010b, 2010c; Perinçek ve diğ., 2011; Perinçek ve diğ., 2014 baskıda). Buna göre Trakya Fay Sisteminin oluşturduğu yükselim alanlarına gidilmesi, bu alanlarda arama yapılması önerilmektedir. Yükselim alanları dolayında Danişmen Formasyonunun üstten kısmen aşındığı, üstteki Ergene Formasyonu'nun ince olduğu kesimler hedef alanlar olarak seçilmiştir. $\mathrm{Bu}$ yeni strateji yapılan bu çalışmanın en önemli sonuçlarından biridir.

\section{Trakya Havzası'nda Danişmen} Formasyonu içinde yer alan linyit potansiyelinin anlaşılmasına yönelik olarak çalışma kapsamında kuyu korelasyonları, kalınlık ve yapı haritaları yapılmıştır. Haritalar: Osmancık Formasyonu üstü yap1 haritas1, Danişmen Formasyonu üzerindeki diskordans düzleminin (paleotopgrafya) yükseklik haritası, Danişmen Formasyonu kalınlık haritası ve bu birim içindeki linyit katkılarının toplam kalınlık haritasıdır (Perinçek, 2010b, 2010c; Perinçek ve diğ., 2011; Perinçek ve diğ., 2014 baskıda).

TPAO'dan alınan kuyu verileri kullanılarak Osmanc1k Formasyonu yap1 haritası hazırlanmıştır (Perinçek, 2010b, 2010c; Perinçek ve diğ., 2014 baskıda). Osmancık Formasyonu Danişmen Formasyonu'nun hemen altında bulunur ve bu iki birim uyumludur. Osmanckk üstü yap1 haritas1 yardımıyla Danişmen Formasyonu içerisindeki linyit katkılarına hangi alanlarda sı̆̆ derinliklerde ulaşılacağını göstermektedir.
Danişmen Formasyonu üzerinde bulunan diskordans düzlemi de haritalanmıştır (Perinçek, 2010a, 2010b, 2010c; Perinçek ve diğ., 2014 baskıda). $\mathrm{Bu}$ harita Paleotopografya haritası olarak değerlendirilmelidir. Paleotoğrafya haritası diskordans düzleminin yüksek olduğu alanları da gösterir. Dolayısıyla bu alanlarda Danişmen Formasyonu içindeki linyit düzeyleri de yüksek kotlarda bulunur ve yüzeye yakındır. Bu nedenle, Danişmen Formasyonu üstü diskordans düzlemi haritası, linyit aramalarına katk1 veren önemli bir araçtır. Osmancık Formasyonu ile Danişmen Formasyonu dereceli geçişli ve konkordandır. Danişmen Formasyonu'nun üst sınırı ise uyumsuzdur ve bazı alanlarda önemli oranda aşınmıştır.

Danişmen Formasyonu'nun havzadaki kalınlık dağılımı linyit aramaları açısından önemlidir. Bu öngörüden hareketle TPAO kuyu verileri kullanılarak hemen hemen havzanın tümü için Danişmen Formasyonu kalınlık haritası yapılmıştır (Perinçek, 2010a, 2010b, 2010c; Perinçek ve diğ., 2014 baskıda). Bu harita Trakya Fay Sistemi sonrası aşınmanın önemini göstermektedir. Fay zonu boyunca ve fayın oluşturduğu yükselim alanlarında yer yer Danişmen Formasyonu'nun aşınma nedeniyle ortadan kaldırıldığı ve bazı alanlarda da kalınlığının 0-300 metre arasında değiştiği görülür. Danişmen Formasyonu'nun kalınlığ 1600 metreye kadar ulaşmaktadır.

Danişmen Formasyonu kalınlık haritası linyit arama politikası için aşağıda sıralanan önemli sonuçları sağlamış, linyit arama politikasına yön vermiştir.

1. Trakya Fay Sisteminin yarattığ 1 yükselim alanlarında Danişmen Formasyonu fay sisteminin oluşumunu takiben yükselmiş ve aşındırılmıştır. Trakya Havzası'nın kuzeydoğusunda Danişmen Formasyonu'nun 
olmamasının veya ince olmasının nedeni birim çökelirken bu alanın havza kenarı olmasıdır. Trakya Havzası'nın güney kesiminde Danişmen Formasyonu'nun incelme nedeni ise yapısaldır. Bu kısım Trakya Havzası'nın derin kesimine rastladığ1 halde Danişmen Formasyonu güney yönünde incelmektedir. Bunun nedeni KAF'ın yarattığ1 yapısal yükselimdir. KAF'la ilgili yükselim sonrası Marmara Denizi kıyısı boyunca Tekirdağ-Silivri arasındaki alan yükselmiş ve bu alanda Danişmen Formasyonu tümüyle, Osmancık Formasyonu ise kısmen aşınmıştır.

2. Kuzey Anadolu Fayı (KAF) Trakya Havzası'nda etkinliğini sürdürürken fay zonuna açılı gelen an-eşhelon yapılar gelişmiştir. Buna en iyi örnek Hamitabat gaz sahasıdır. Bu sahada bazı kuyularda Danişmen Formasyonu tümüyle aşındırılmıştır, dolayısıyla linyit katkıları da bu alanda hiç görülmez.

3. Danişmen Formasyonu üzerindeki Ergene Formasyonu'nun kalınlığı ve buna ilave olarak Danişmen Formasyonu'nun üst kısmındaki linyit katkısız kesimin kalınlığı birbirine eklenince linyit katkılarına ekonomik derinliklerde ulaşılması güçleşmektedir. Bu nedenle söz konusu birimlerin kalın olduğu yerlerden uzak durulmalıdır.

\section{Ergene Formasyonu - Kircasalih formasyonları toplam Kalınlık Haritası:}

Ergene - Kırcasalih formasyonlarının toplam kalınlığı linyite ulaşmak için önemli ilk engeli oluşturur ve işin başlangıcında dikkate alınması gerekir. $\mathrm{Bu}$ nedenle ilk yapılan harita bu formasyonlarının toplam kalınlık haritası olmuştur (Şekil 12). TPAO ve bazı MTA ve TKİ kuyularında Ergene Formasyonu ve bunun hemen üzerindeki Kırcasalih (Trakya) Formasyonu ayrılmamıştır. $\mathrm{Bu}$ nedenle Ergene Formasyonu kalınlık haritası ve Kırcasalih Formasyonu kalınlık haritası birlikte çizilmiştir. Trakya Havzası'ndaki bazı sismik kesitlere bakıldığında söz konusu iki formasyon arasında uyumsuzluk görülmektedir (Şekil 8). Şekil 12 Ergene ve Kırcasalih formasyonlarının toplam kalınlığını göstermektedir. Lüleburgaz güneydoğusunda kalınlığın 1400 metreye ulaştığı görülür. Trakya Havzası kenarlarında da Ergene ve Kırcasalih formasyonları incedir. Şekil 12 ayrıca linyitin aşındığı ya da Danişmen Formasyonunun fasiyesinin linyit açısından olumsuz olduğu kesimler "linyitsiz alan" olarak gösterilmiştir. Ergene ve Kurcasalih formasyonlarının toplam kalınlığının 400 metreden daha ince olduğu yerlerde ancak Danişmen Formasyonu içindeki linyite ekonomik olarak ulaşma şansı vardır. Söz konusu formasyonların 500m den kalın olduğu alanlarda linyit aramalarında uzak durulmalıdır. Aynı alanlarda linyit kalınlık toplamı yeterli ve ekonomik düzeyde olabilir fakat ekonomik olmayan derinliklerdedir.

Trakya Fay Sistemi, Trakya Havzası'nın doğu kesiminde Vakıflar-1 İstanbul arasında Ergene Formasyonu çökelimini takiben tekrar harekete geçmiş Ergene Formasyonu tabanındaki diskordans düzlemi Ergene Formasyonu ile birlikte kıvrımlanmıştır (Şekil 8). Bunun sonucunda Ergene Formasyonu, kıvrımlanıp antiklinal oluşturduğu alanlarda kısmen aşınmıştır. Aşınma alanlarının bulunduğu paleo-yükselimler Kırcasalih Formasyonu'nun kalınlığının da ince olduğu alanlardır. Kırcasalih Formasyonu'nun çökelimi sırasında ve sonrasında da Trakya Fay Sistemi üzerinde fay aktivitesi sürmüştür. $\mathrm{Bu}$ aktivite sonrası Kırcasalih Formasyonu'nun çok az eğim kazandığı kıvrımlandığı görülür. Söz konusu aktivite Trakya Havzasının doğu kesimlerinde görülür. Bunun nedeni söz konusu alanın KAF’ın aktif olduğu Marmara Denizi'ne yakın olmasıdır. 


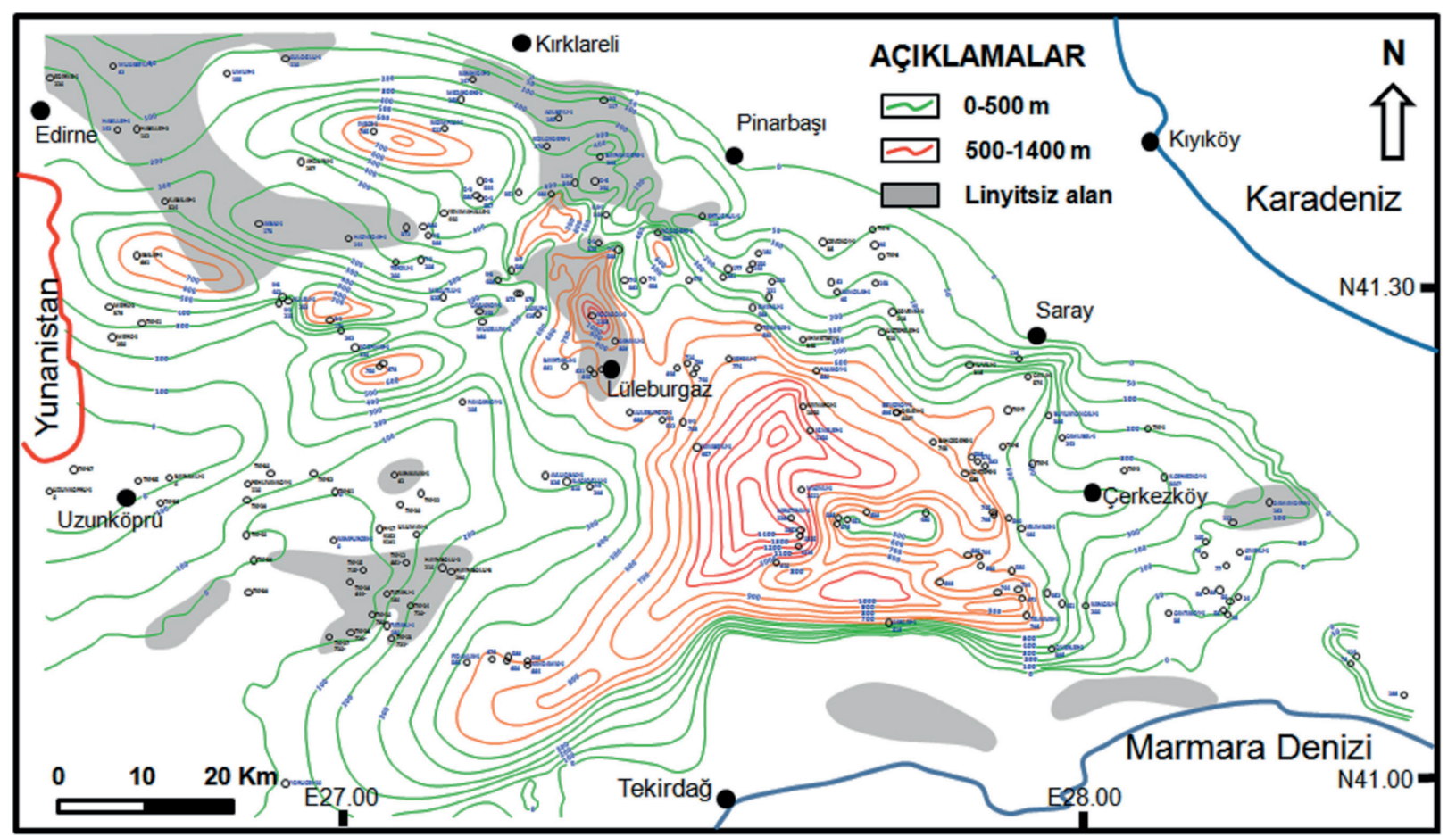

Şekil 12. Ergene Formasyonu kalınlık haritası. Harita yorum katılarak elle konturlanmıştır.

Figure 12. Thickness map of the Ergene Formation. Interpretive contouring conducted by hand.

Kuyu verileri ile Danişmen Formasyonu ve içindeki linyit seviyelerinin korelasyonu

Çalışmanın ilk aşamasında, Trakya Havzası'nda kuyu korelasyonu yapılmış ve bu korelasyon sırasında bazı MTA ve TKİ kuyularında alttaki linyit zonlarının, kuyu derinliğinin yeterli olmaması nedeniyle kesilmediği anlaşılmıştır. Soğucak 1, Akıncılar 1, Topçu 1 TPAO kuyularıyla bunların kuzeyindeki TKİ kuyularının korelasyonu yapılmıştır (Şekil 13ve 14). Bu korelasyonda TKİ kuyularının TPAO kuyularında kesilen yüzeye en yakın linyit katkısına kadar ulaştığı görülmektedir. Fakat TKİ kuyuları yeterli derinlikte olmadığından TPAO kuyularında gözlenen üstten 2. ve 3 . linyit katkılarına ulaşmamıştır. $\mathrm{Bu}$ çalışmada verilen toplam linyit kalınlık haritalarında sığ MTA ve TKİ kuyularında daha aşağı kotlarda kesilmesi beklenen diğer linyit düzeyleri hesaba katılmamıştır. Dolayısıyla Şekil 7'de verilen toplam linyit kalınlık haritası minimum toplam linyit kalınlığını temsil etmektedir, Toplam linyit kalınlık haritalarında görülen kalınlıklar bazı alanlarda daha fazla da olabilir. Bu harita toplam linyit kalınlığı olarak eldeki verilere göre olabilecek en az kalınlıkları içermektedir. Özetle haritada gösterilen veriler, varlığı kesin tespit edilemeyen kalınlıkları içermemektedir.

Şekil 13 ve Şekil 14'de verilen korelasyonda linyit katkılarının yanal yönde süreksizlikler gösterdiği görülür. Linyit katkılarının kuyular arasında uzun mesafeler devam etmediği gözlenmiştir. Linyitli seviyelerin en fazla 2-3 kuyu arasında birbiri ile korelasyonu yapılabilmiştir. Bu süreksizlik ortam koşullarının yanal ve düşey yönde sık değişmesi nedeniyledir.

Linyit katkıları çoğunlukla marn içinde yer alır. Çakıllı, kumlu, kireçli düzeyler çoğunlukla 
linyit içermez. Ayrıca şeyl seviyelerinin hakim olduğu alanlarda da linyit görülmemiştir.

Bu çalışmada Vize GB'sındaki kuyuların kendi aralarında korelasyonu yapılmıştır. Kuyu korelasyon yapılan diğer 2 alan ise Hayrabolu batısı ve Uzunköprü-Pehlivanköy dolayıdır. Söz konusu 3 alanda yapılan korelasyonlar Şekil 13, $14,15,17$, ve 18 'te sunulmuştur.

Vize Güneybatısı: TKİ Vize ruhsatları alanında yapılan toplam linyit kalınlık haritası Şekil 24 de verilmiştir. Aynı alanda yapılan korelasyonlarda (Şekil 13 ve Şekil 14) TKİ-66, TKİ-51, TKİ-54, TKİ-49, TKİ-58, TKİ-57 kuyuları dışındaki diğer tüm kuyularda linyit kesilmiştir. TKİ-61 ve TKİ-56 kuyularında kesilen iki linyit seviyesinin kalınlığı toplam 4 metredir. Aynı kuyularda altta ve üstte başka linyit seviyeleri de kesilmiştir. Kuyularda kesilen linyit kalınlıkları 1-4 metre arasında değişmektedir. Bu alanda yapılan korelasyonlara bu alan civarındaki Soğucak 1, Akıncılar 1 ve Topçu 1 TPAO kuyuları da ilave edilmiştir. TPAO kuyularında dikkati çeken konu linyit seviyelerinin kalınlıklarının abartılmış olmasıdır. TKİ kuyularında tek bir linyit seviyesi en fazla 4 metre olduğu halde TPAO kuyularında ise 12-15 metre kalınlıklara ulaşan linyit seviyeleri gösterilmiştir. Bu kıyaslama TPAO kuyularında linyit olarak gösterilen seviyelerin gerçeği yansıtmadığını gösterir. TKİ kuyularında TPAO kuyularının en üst kesiminde bulunan linyit düzeyleri test edilmiştir. Korelasyondan elde edilen bilgiye göre TKİ-65 ve TKİ-66 kuyuları derinleştirilseydi TPAO kuyularında daha aşağıdaki kotlarda bulunan linyit düzeylerinin yanal devamı daha ince de olsa kesilmesi mümkün olacaktı. Dikkat edilmesi gereken diğer bir nokta ise TPAO kuyularında derinde (250-360 metre) görülen linyit seviyelerinin 500 metre derinlikte olan TKİ 64 ve TKİ 48 kuyularında görülmemesidir. $\mathrm{Bu}$ durum dikkat çekicidir. Bu kuyularda TPAO kuyularında aşağıdaki kotlarda görülen linyit düzeylerinin kesilmemesinin nedeni Danişmen Formasyonunun fasiyesinin linyit birikimi için uygun olmadığı şeklinde yorumlanmıştır. Linyit birikimi için gerekli düşük enerjili ortam koşulları (bataklık-göl) bu kuyular civarında sağlanmamış olabilir. TKİ 64 ve TKİ 48 kuyularının sonuçları da dikkate alınarak sahanın güneyindeki birkaç kuyunun derinleştirilmesi önerilmektedir. Ĕger Topçu-1 kuyusunda 350 metre civarındaki linyit seviyesi gerçek ise bu durumda TKİ 65-66-67 ve 68 kuyuları derinleştirilerek veya bu kuyular civarında yeni kuyular açılarak Topçu-1'deki en alttaki linyit seviyesi test edilebilir. Yeni açılacak kuyular aşamalı olarak delinmeli en güneyde açılacak ilk kuyunun sonucuna göre ikinci, üçüncü kuyu açılmalıdır. Bu açılacak kuyularda Soğucak-1, Akıncılar-1 ve Topçu-1 kuyularında alt seviyelerde gösterilmiş bulunan linyit düzeyleri kesilecek olursa Vize sahası için ek bir potansiyel ortaya çıkacak ve bu sahanın rezervi daha da artacaktır.

TKİ Vize ruhsatlarının bulunduğu alanda korelasyon yapılırken TKİ kuyularının üst kısmında sondaj sirasında tanımlanan, rapor ve kuyu loglarında gösterilen formasyon (Ergene ve Danişmen formasyonları) tanımları, Şekil 16'da görülen son baskı MTA jeoloji haritası kullanılarak kısmen değiştirilmiştir. $\mathrm{Bu}$ değişim yapılırken jeoloji haritasında mostrada görülen Ergene ve Danişmen formasyonlarının sınırının Kırcasalih (Trakya) Formasyonu altındaki devamı yorum yapılarak kesikli çizgiyle gösterilmiştir (Şekil 16). Kurcasalih Formasyonu altında doğudan batıya uzanan hattın kuzeyinde Kurcasalih Formasyonu doğrudan Danişmen Formasyonu üzerindedir. Hattın güneyinde ise Kırcasalih Formasyonu altında Ergene Formasyonu, bununda altında da Danişmen Formasyonu yer alır. Jeoloji haritasına dayalı yorumdan sonra kuyu loglarında gösterilen üstteki formasyonların dağılımı bu yoruma göre değiştirilmiştir. 


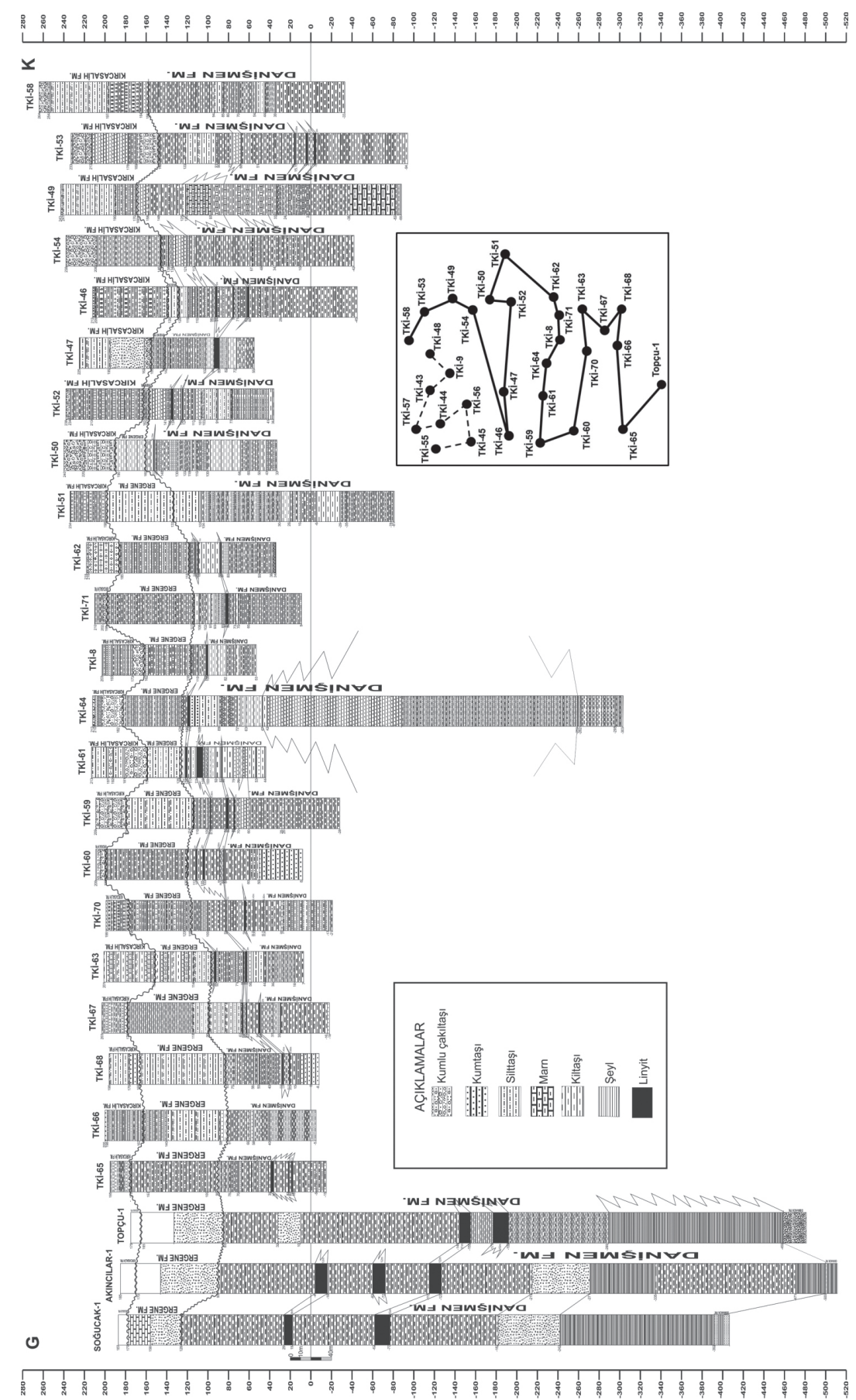

Şekil 13. Vize dolayındaki ruhsatlarında ve açılan kuyularda Danişmen, Ergene ve Kırcasalih formasyonlarının stratigrafik korelasyonu. Korelasyon güneydeki TPAO kuyularından (Soğucak-1, Akıncılar-1, Topçu-1) başlayarak kuzey yönünde TKİ kuyuları (TKİ-65, TKİ-66....TKİ-53, TKİ 58) kullanılarak yapılmıştır.

Figure 13. Stratigraphic correlation of Danişmen, Ergene and Kircasalih formations conducted in the Vize permits areas. Correlation begins from TPAO wells (Soğucak-1, Akıncılar-1, Topçu-1) in the south continue to north through TKI wells (TKI-65, TKI-66...TKI-53, TKI 58). 


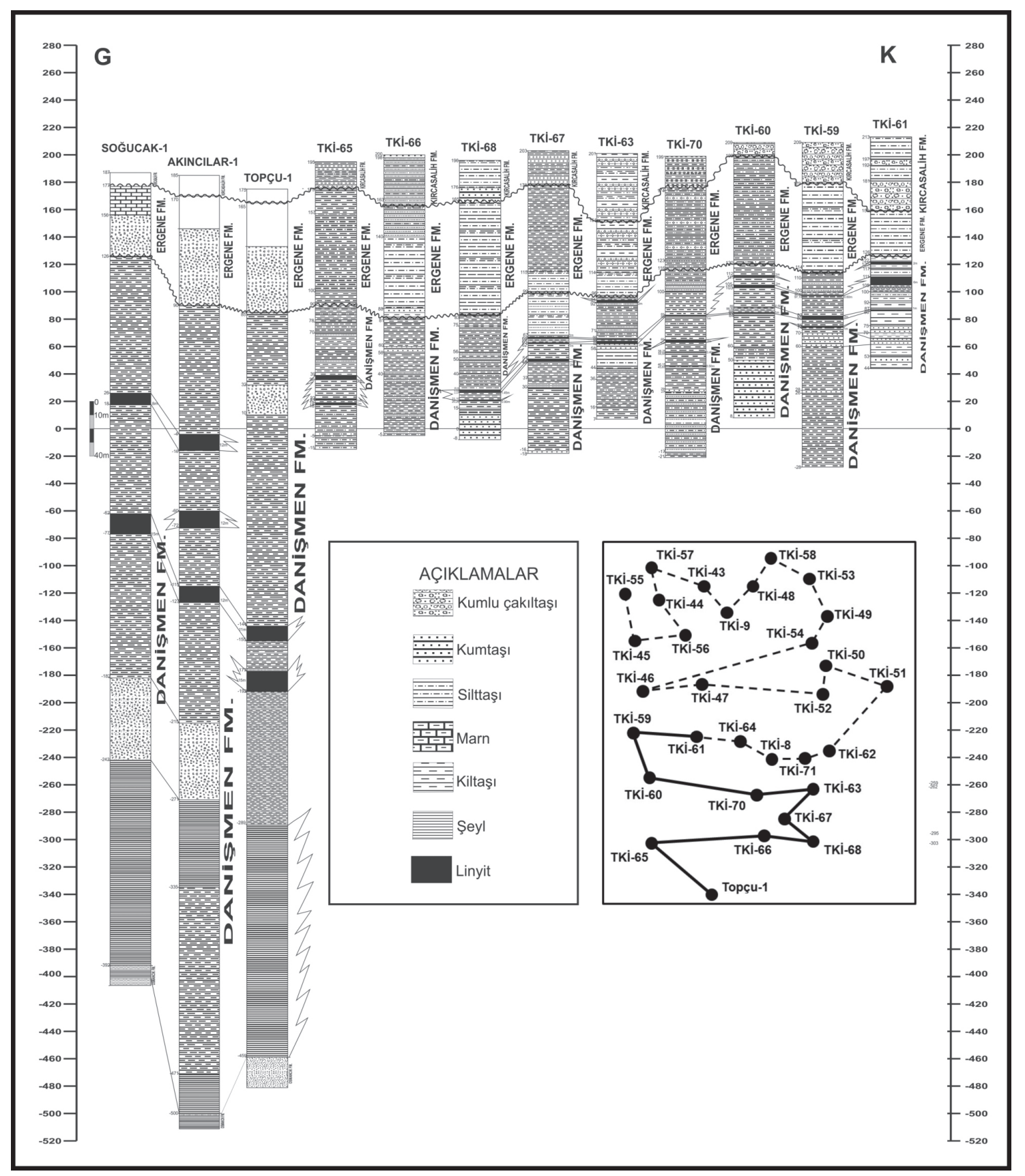

Şekil 14. Şekil 13 'te görülen kuyu korelasyonunun güney kesimi düşey ölçeği büyültülerek burada tekrar sunulmuştur. Korelasyon güneydeki TPAO kuyularından (Soğucak-1, Akıncılar-1, Topçu-1) başlayarak kuzey yönünde TKİ kuyuları (TKİ-65, TKİ-66....TKİ-59, TKİ 61) kullanılarak yapılmıştır.

Figure 14. Southern portion of Figure 13 is represented here as vertical scale of the correlation is increased. Correlation begins from TPAO wells (Soğucak-1, Akıncllar-1, Topçu-1) in the south continue to north through TKI wells (TKI--65, TKİ-66....TKİ-59, TKI 61). 


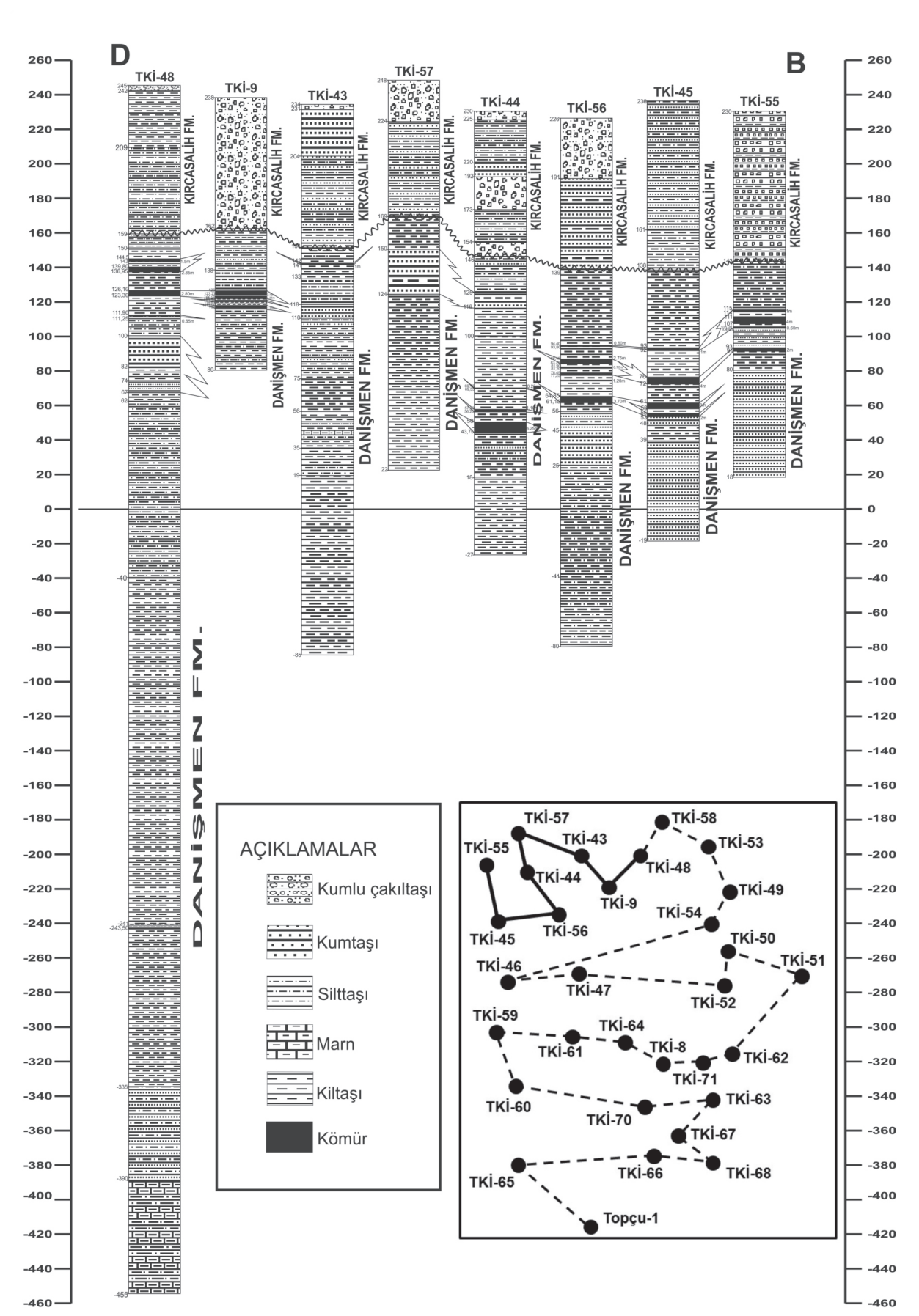

Şekil 15. TKİ Vize ruhsatlarının bulunduğu alanda açılan kuyularda Danişmen, Ergene ve Kırcasalih formasyonlarının stratigrafik korelasyonu. Bu korelasyon Şekil 13'ün kuzey devamıdır (TKİ-48, TKİ9....TKİ-45, TKİ-55).

Figure 15. Stratigraphic correlation of Danişmen, Ergene and Kircasalih formations conducted in the area of Vize permits. This correlation is present northern extension of the figure 13 (TKI-48, TKI-9...TKI-45, TKI$55)$. 


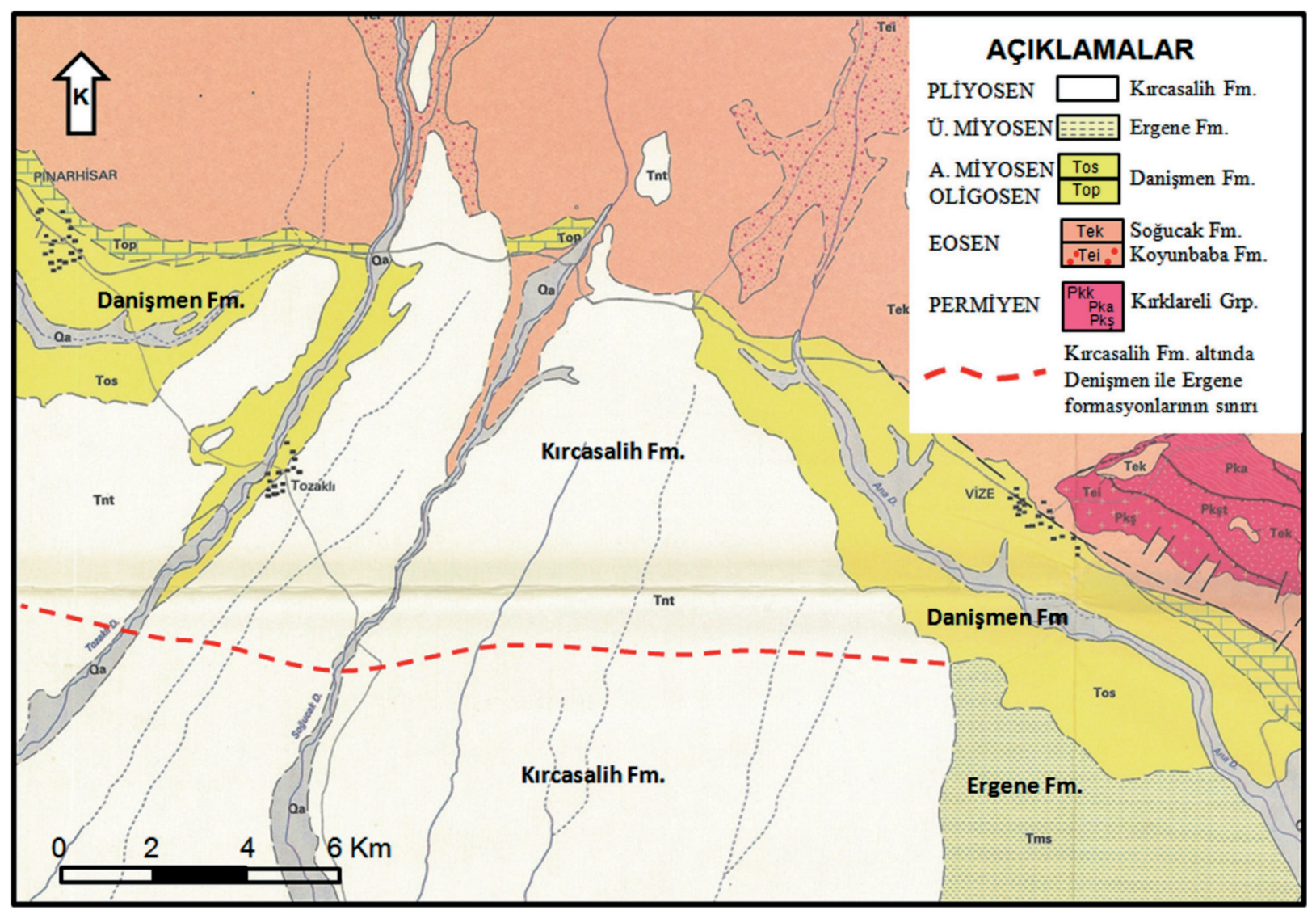

Şekil 16. TKİ, Vize ruhsatlarının bulunduğu jeoloji haritası (MTA, 1998). Danişmen ve Ergene formasyonları arasındaki sınır ve bunun Kırcasalih Formasyonu altındaki devamı jeoloji haritasında kesikli çizgi ile gösterilmiş.

Figure 16. Geology map of the TKI Vize permits (MTA, 1998). Boundary between Danişmen and Ergene formations were covered and sealed by Kircasalih Formation that is shown with dotted line.

Çerkezköy Dolayı: TKİ-2, TKİ-1, TKİ-3, TKİ-4, TKİ-5, TKİ-6, TKİ-7 kuyular1 arasında yapılan korelasyonda Danişmen Formasyonu içindeki linyit katkılarının çok az olduğu görülmektedir (Şekil 17). Korelasyonda kullanılan kuyulardan sadece TKİ-1 ve TKİ-2'de linyit seviyeleri gözlenmiş olup, bu kuyularda kesilen linyit kalınlıkları $0.25 \mathrm{~m}$. ile $1.35 \mathrm{~m}$. arasında değişmektedir. Diğer kuyularda ise linyit kesilmemiştir. Burada açılan kuyularda Danişmen
Formasyonu; kumtaş1, çakı1llı kumtaşı ve çakıltaşı katkıları içerdiği için linyit birikimi açısından olumsuz olduğu görülmüştür. TKİ-4 kuyusunda belirlenen çakıllı kumtaşı ve çakıltaşı katkılarının çökeldiği akarsu ortamı linyit oluşumu için olumsuz koşullar yaratmıştır.

TKİ-3 ve TKİ-4 kuyuları yüzeyde Kırcasalih Formasyonu diğer kuyular ise yüzeyde Ergene Formasyonu ile başlar. 


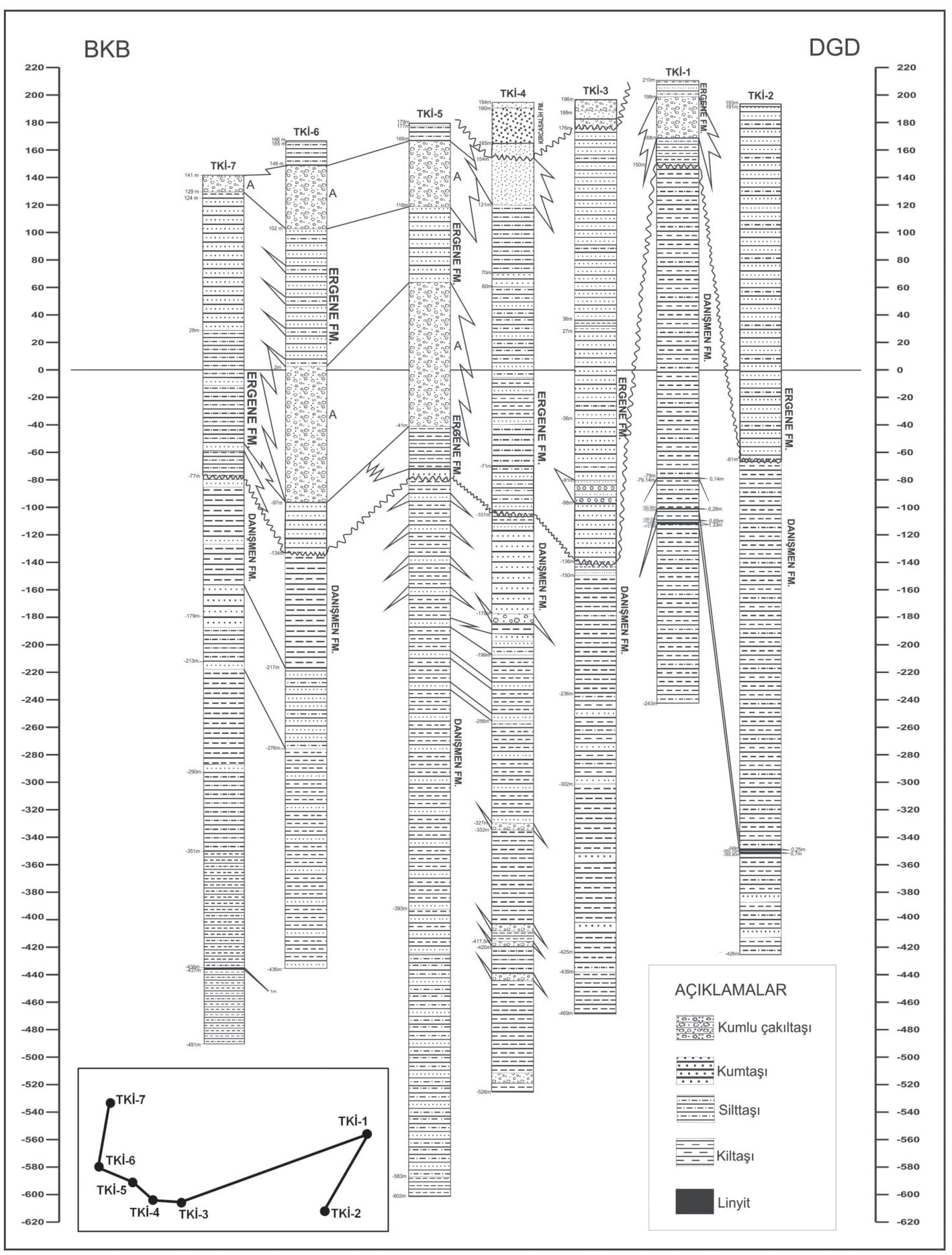

Şekil 17. Çerkezköy dolayında TKİ tarafından açılan kuyularda Danişmen, Ergene ve Kırcasalih formasyonlarının stratigrafik korelasyonu.

Figure 17. Stratigraphic correlation of Danişmen, Ergene and Kircasalih formations conducted around Çerkezköy district, using wells were drilled by TKI. 


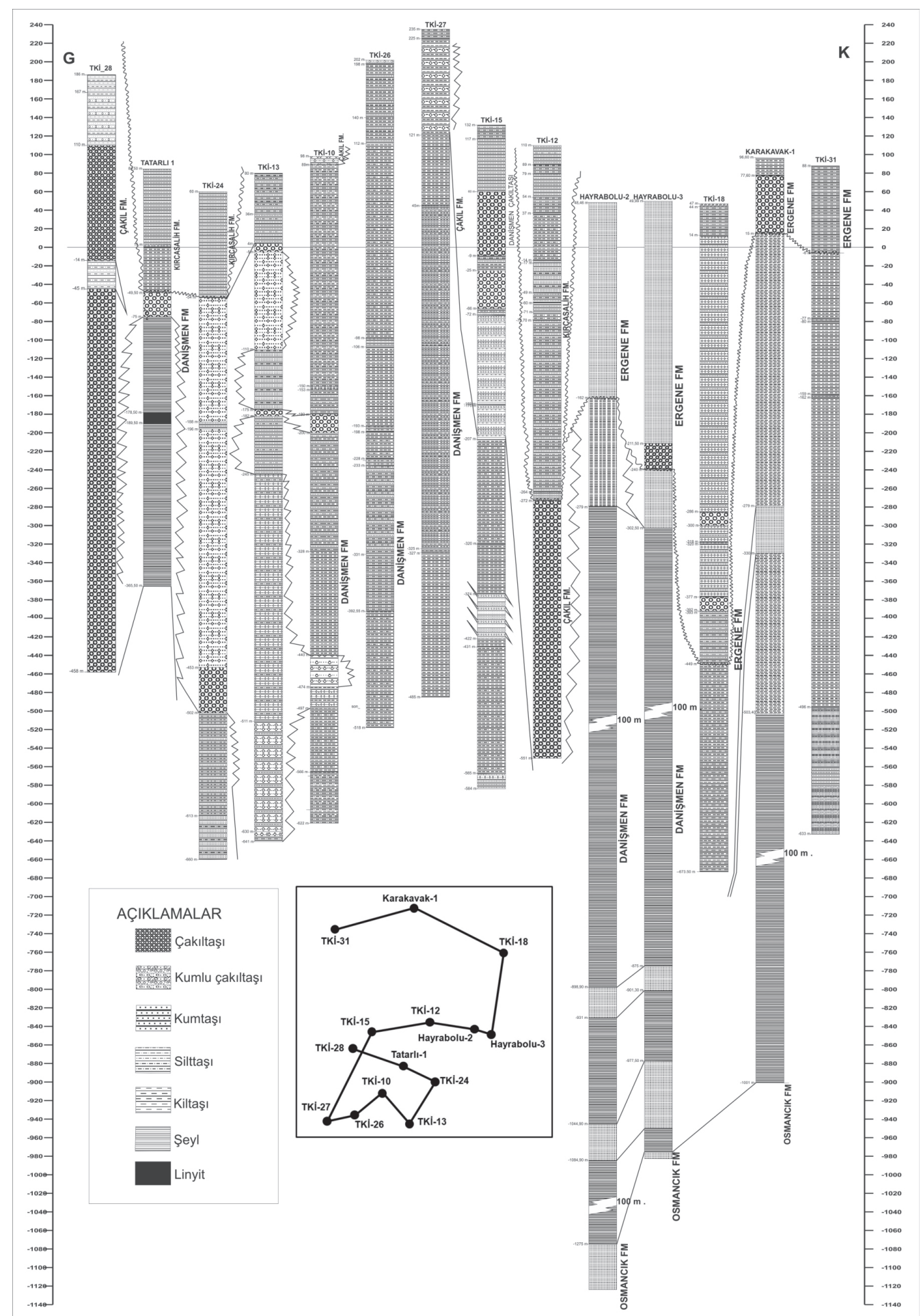

Şekil 18. Hayrabolu dolayında TPAO ve TKİ tarafından açılan kuyularda Danişmen, Ergene ve Kırcasalih formasyonlarının stratigrafik korelasyonu.

Figure 18. Stratigraphic correlation of Danişmen, Ergene and Kurcasalih formations conducted around Hayrabolu district, using wells were drilled by TKI. 
Hayrabolu Dolayı: Bu korelasyon, TKİ31, Karakabak-1, TKİ-18, Hayrabolu-3 ve 2, TKİ12, TKİ-15, TKİ-27, TKİ-26, TKİ-10, TKİ-13, TKİ-24, Tatarl1-1, TKİ-28 arasında yapılmıştır (Şekil 18). Korelasyonda yer alan Tatarl1-1, TKİ-26 kuyuları dışında hiçbir kuyuda linyit kesilmemiştir. Kuyularda kesilen Danişmen Formasyonunda; genellikle çakıltaşı, çakıllı kum fasiyesinin egemen olduğu görülmektedir. Hayrabolu-2 ve 3 kuyularında ise istifin önemli bir kısmının şeyl ile temsil edildiği ve kumtaşı ara katkıları içerdiği görülür. Danişmen Formasyonu marn düzeyleri çoğunlukla linyit katkıları içermesine rağmen Hayrabolu civarında TKİ tarafindan açılan kuyuların marnlı düzeyleri de linyitsizdir. $\mathrm{Bu}$ alanda linyit olmamasının nedeni; Danişmen Formasyonunun fasiyesidir. Göl bataklık ortamında çökelen marn düzeyleri linyit içerirken, taşkın düzlüklerinde çökelen marn linyitsizdir. Çakıltaşı, çakıllı kum, kum yüksek enerjili akarsu ve benzeri ortamını gösterir. Hayrabolu civarında çakıllıkumlu fasiyes oldukça yaygındır. Linyitin oluştuğu bataklık ve göl alanlarının burada olmadığı veya çok sınırlı olduğu sonucuna varılmıştır (Perinçek 2010a, 2010b ve 2010c, Perinçek ve diğ., 2014 baskıda). Şengüler ve diğ. (2000) makalelerinde Trakya Havzası kömürlerinin yayılımı, özellikleri, çökelim modeli yanında bölgede bilinen saha ve işletmelere de yer verilmiştir. Trakya Havzası'nın kömürleri; gölsel ortamların delta bataklıklarında çökelmiştir. Çökme hızının yüksek olması çökel kalınlığının fazla olmasına neden olmuş, bu ise kömür damarlarının korelasyonunu güçleştirmiştir (Şengüler, 2013).

Çöpköy-Uzunköprü Dolayı: Korelasyon güneyden kuzeye TKİ-38, TKİ-39, TKİ-29, TKİ30, Pehlivanköy-1, Bayraml1-1, TKİ-36, TKİ31, TKİ-35, Uzunköprü-1, Meriç-1, Meriç-2 kuyuları arasında yapılmıştır (Şekil 19). Kuyular yüzeyde Kurcasalih ve Ergene Formasyonlarından başlamaktadır. Bazı kuyularda bu ayırım yapılmamış ya da eksik yapılmıştır. Şekil 20 Çöpköy dolayının Jeoloji haritasını göstermektedir. Çöpköy dolayında delinen kuyuların loglarında Kırcasalih Formasyonu ve Ergene Formasyonu çoğu kez ayrılmamış veya birbiri ile karıştırılmıştır. Bu alanda açılan kuyularda kesilen birimler jeoloji haritası dikkate alınarak yeniden değerlendirilmiştir. Jeoloji haritasından (Şekil 20) yararlanılarak kuyularda Kircasalih veya Ergene formasyonlarından hangisinin kesildiğine karar verilmiş, bu doğrultuda kuyu korelasyonlarında gereli düzeltmeler yapılmıştır. Meriç-1 ve 2, Uzunköprü-1, Bayramlı-1 ve Pehlivanköy-1 kuyularında linyit kesilmesine karşın aynı alanda TKİ kurumu tarafindan denilen kuyular içinde sadece TKİ-35 ile 32 ve 25 cm' lik 2 linyit katkısı kesilmiştir. Uzunköprü dolayında ve Meriç kuyularının olduğu alanda linyit beklentisi vardır. TKİ-38, TKİ-39, TKİ-29 kuyuları dolayında Danişmen Formasyonu'nun fasiyesi linyit oluşumuna uygun değildir. Söz konusu kuyuların güneyinde Danişmen Formasyonu'nun çakıltaşı düzeyleri mostra verir. Çakııltaşı düzeylerinin arttığ1 kesimlerde Danişmen Formasyonu içindeki linyit potansiyeli azalmaktadır. TKİ-31 kuyusunda yaklaşık 500 metre marn kesilmiştir. Linyit katkıları genellikle marn içerisinde gözlenmesine karşın bu kuyuda hiç linyit kesilmemiştir veya sondaj sırasında aslında şeyl olan seviyeler marn olarak tariflenmiş olabilir. Pehlivanköy-1, Bayraml1-1, Uzunköprü-1, Meriç-1 ve 2 kuyularında kesilen linyit marn içindedir. Pehlivanköy-1, Bayramlı-1 ve Uzunköprü-1 kuyularının alt kesimlerinde Danişmen Formasyonu şeyl ve kum ile temsil edilir. Trakya Havzasında çalışılan kuyularda kum, çakıl ve şeylin hakim olduğu litolojilerde linyit katkısı görülmemektedir. Şeyl çoğunlukla Danişmen Formasyonu'nun alt kısımlarında vardır. Eğer Danişmen Formasyonu üstten önemli oranda aşındırılmış ise bu aşınma çoğunlukla linyit katkılı marn düzeylerini ortadan kaldırmıştır. Linyit aramaları yapılırken Danişmen Formasyonu'nun üst kısmının aşırı aşındırıldığı yerlerden uzak durulmalıdır. 


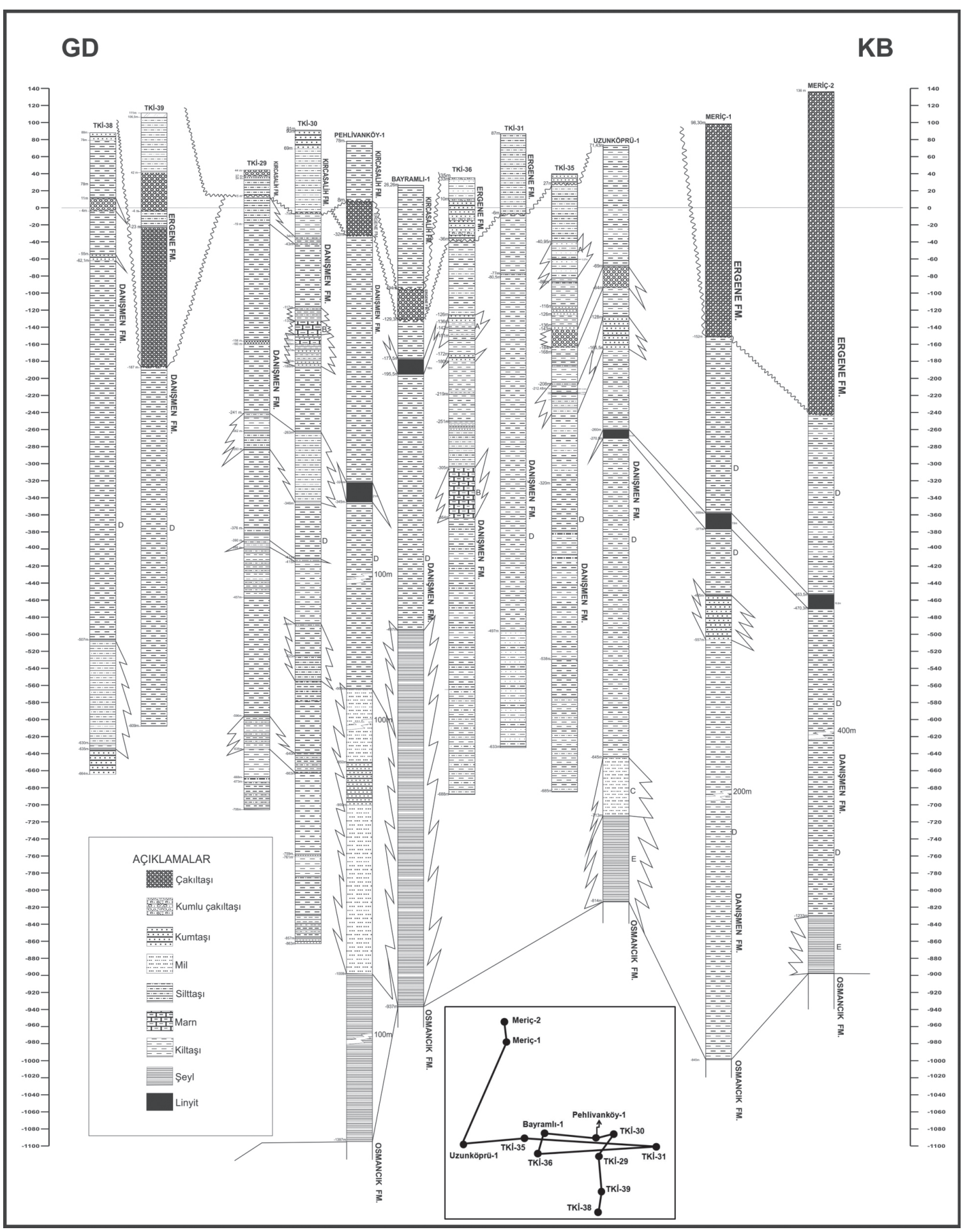

Şekil 19. Çöpköy-Uzunköprü dolayında TPAO ve TKİ tarafından açılan kuyularda Danişmen, Ergene ve Kırcasalih formasyonlarının stratigrafik korelasyonu.

Figure 19. Stratigraphic correlation of Danişmen, Ergene and Kırcasalih formations conducted around ÇöpköyUzunköprü district, using wells were drilled by TKI. 


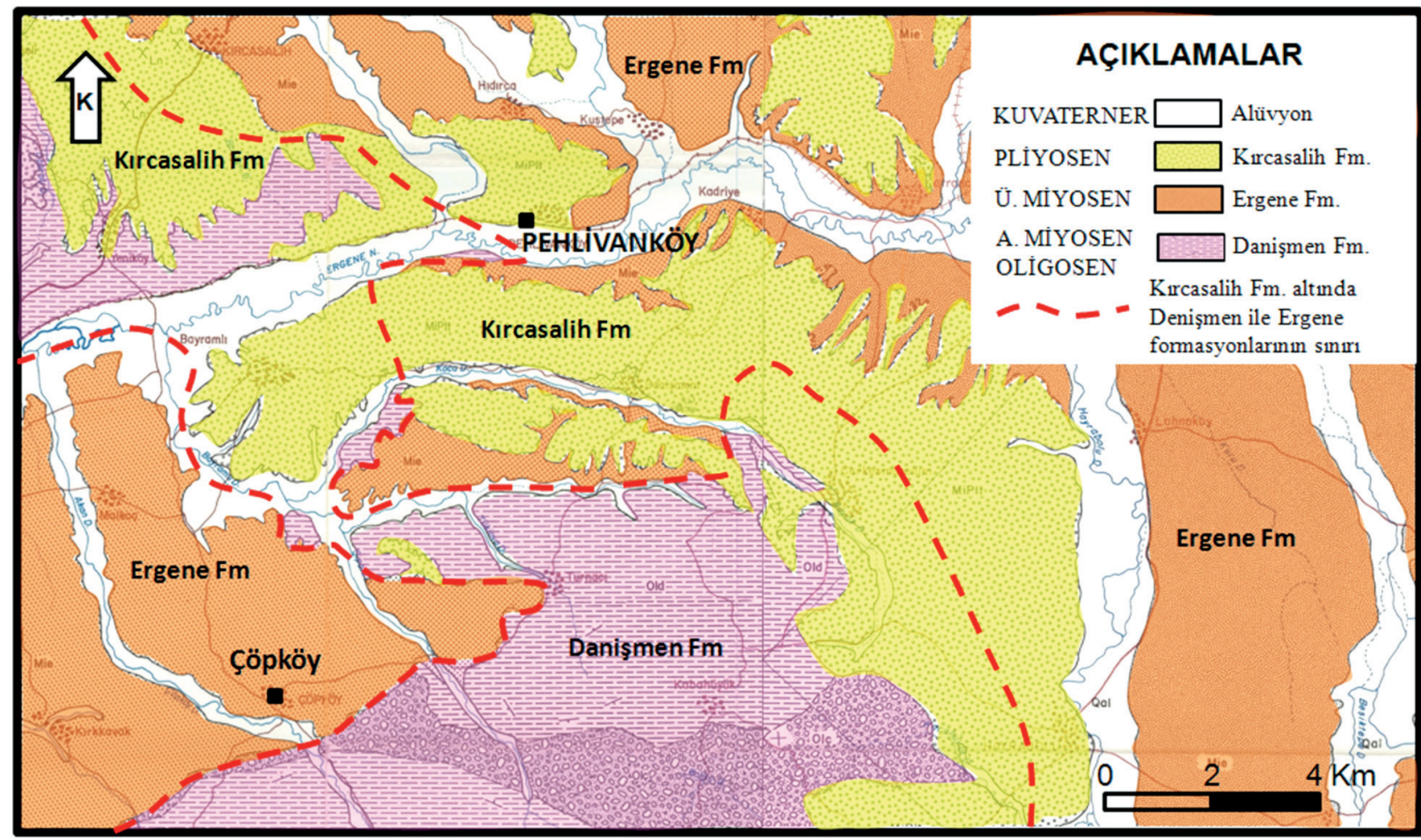

Şekil 20. Çöpköy dolayının Jeoloji haritası (MTA, 1988). Haritada Ergene Formasyonu ile bunun altındaki Danişmen Formasyonu arasındaki sınır yer yer daha üsteki Kırcasalih (Trakya) Formasyonu ile örtülmüştür. Danişmen ve Ergene formasyonları arasındaki sınır ve bunun Kırcasalih Formasyonu altındaki devamı jeoloji haritasında kesikli çizgi ile gösterilmiş.

Figure 20. Geology map of Çöpköy district (MTA, 1988). Boundary between Danişmen and Ergene formations were covered by Kircasalih (Trakya) Formation. The boundary overlain and sealed by Kircasalih Formation is shown with dotted line.

\section{Danişmen Formasyonu İçindeki Linyit Katkılarının Toplam Kalınlık Haritası}

Linyit kalınlı haritası öncelikle Trakya Havzası'nın kuzey ve kuzey doğu alanları için yapılmıştır. $\mathrm{Bu}$ harita linyit birikiminin yoğunlaştığı bataklık ve göl alanlarının yerlerini gösterdiği için ortam değerlendirmesinde yardımcı olur. Linyit seviyeleri fasiyes değişimi ve aşınma nedeniyle yanal yönde süreksizlik gösterir.
Linyit kalınlık haritası yapılırken 2 ayrı veri seti kullanılmıştır. Bunlardan birincisi TPAO kuyuları kullanılarak elde edilen toplam linyit kalınlık haritasıdır. İkincisi ise MTA ve TKİ kuyu verileri kullanılarak elde edilen linyit kalınlık haritasıdır. Bu iki harita çalışmanın ilk aşamasında ayrı ayrı çizilmiştir (Perinçek, 2010a, 2010b, 2010c). $\mathrm{Bu}$ çalışmada sadece MTA, TKİ ve çok az sayıda kullanılan TPAO kuyu verilerine dayalı haritalar sunulmaktadır (Şekil 21, 22, 23, 24, 25, 26 ve 27). 


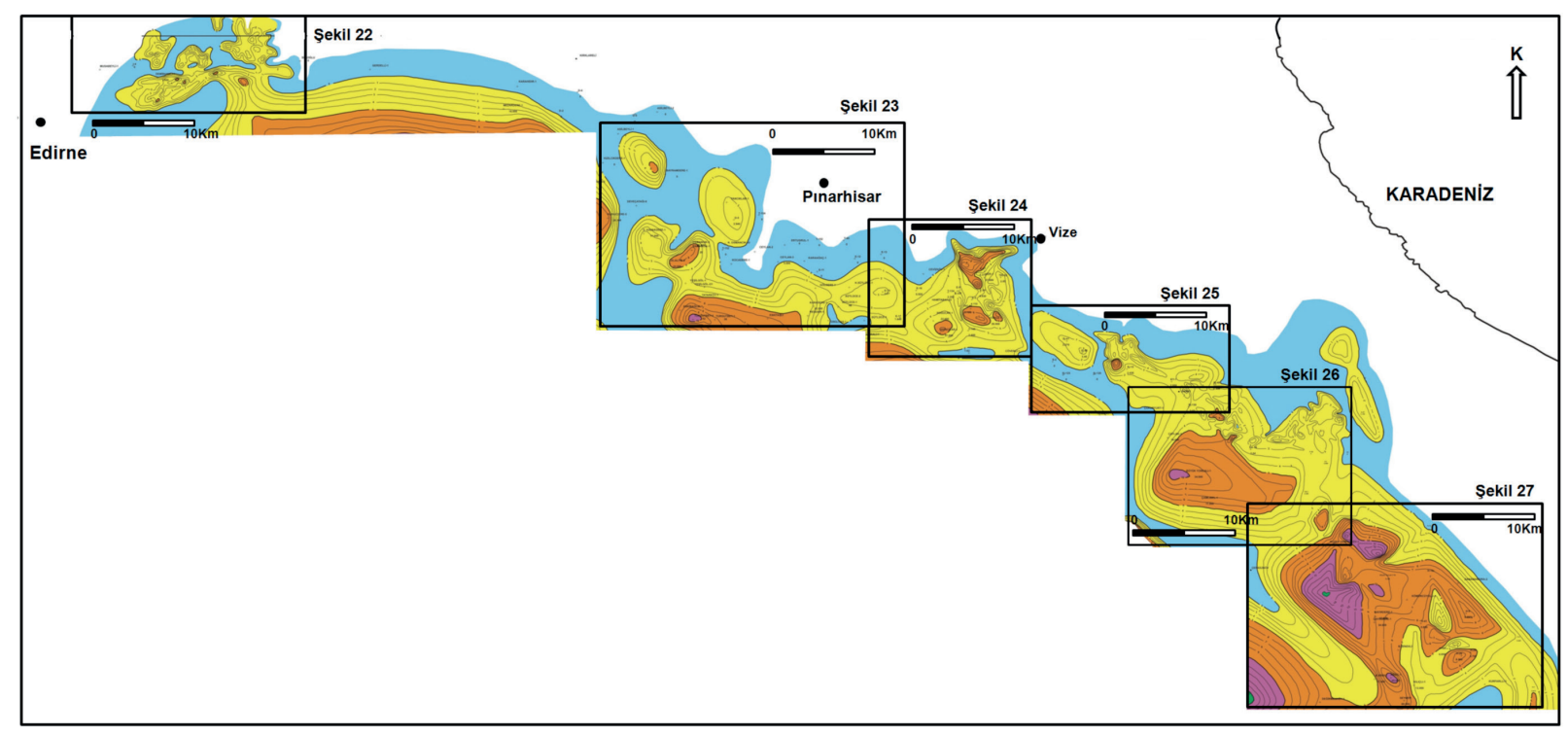

Şekil 21. Çerkezköy, Saray, Vize, Pınarhisar Kırklareli dolayının toplam linyit kalınlık haritası.

Figure 21. Total thickness map of the lignite in Çerkezköy, Saray, Vize, Pınarhisar Kırklareli area.

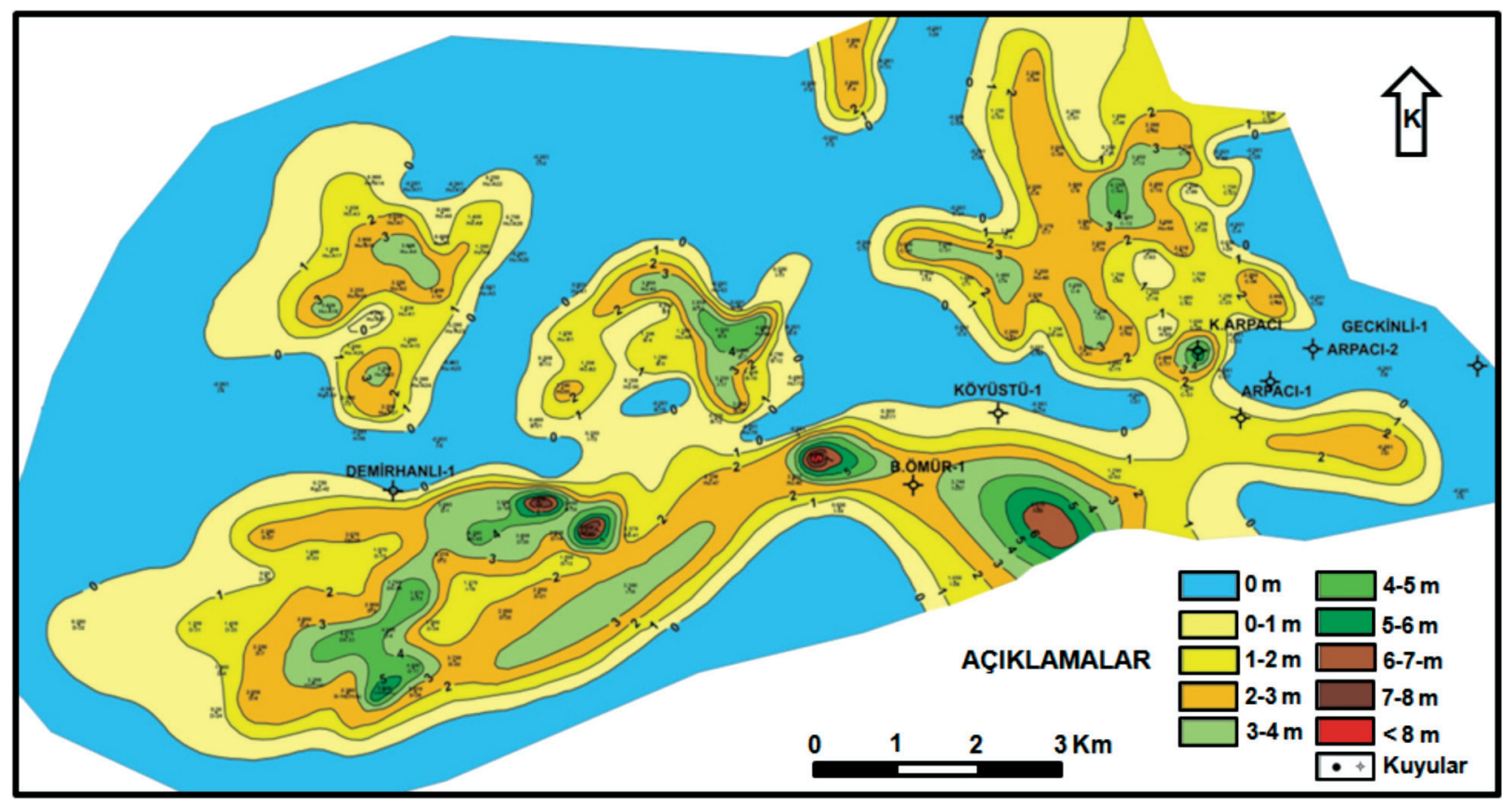

Şekil 22. Edirne kuzeydoğusunda Demirhanlı -1, Arpac1-1 kuyuları arasında Danişmen Formasyonu içindeki linyit katkılarının toplam kalınlık haritası. Lokasyon için Şekil 21'e bakınız.

Figure 22. Total thickness map of the lignite imbedded in Danişmen Formation in northeast of Edirne area around Demirhanl -1, Arpact-1 wells. See Figure 21 for location 


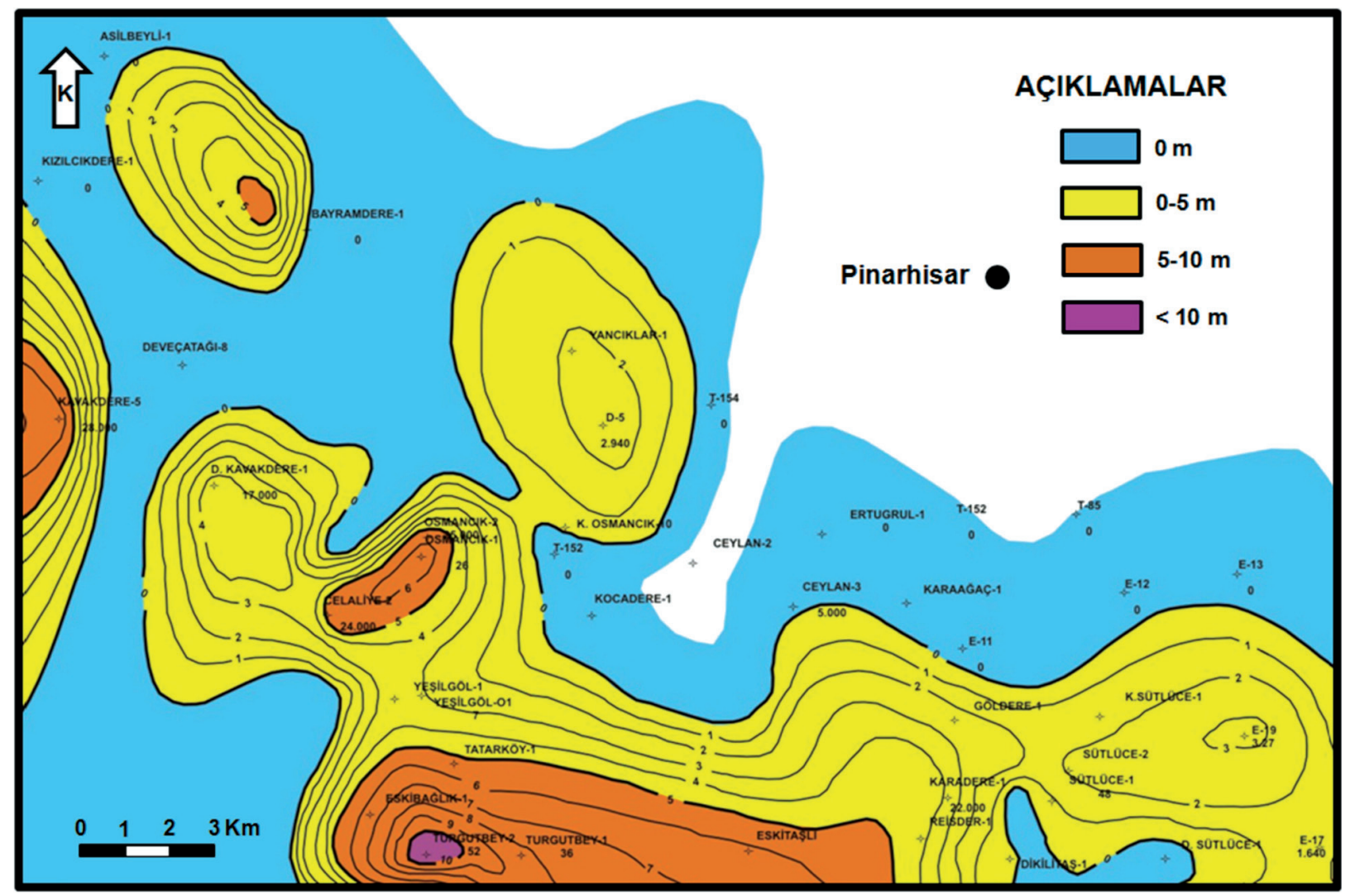

Şekil 23. Kırklaraeli-Pınarhisar güneybatısında Bayramdere-1, Yancıklar-1, Ceylan-1 kuyuları dolayında toplam linyit kalınlık haritası. Lokasyon için Şekil $21^{\text {'e }}$ bakınız.

Figure 23. Total thickness map of the lignite in southwest of Kirklaraeli-Pinarhisar area around Bayramdere-1, Yanciklar-1, Ceylan-1 wells. See Figure 21 for location.

MTA ve TKİ kuyuları genellikle Trakya Havzası'nın kuzeydoğu kenarı boyunca Danişmen Formasyonu'nun yüzeyde olduğu ve Ergene ve Kırcasalih (Trakya) formasyonlarının ince olduğu alanlarda delinmiştir. Bu nedenle yapılan toplam linyit kalınlık haritası sadece havzanın kuzeydoğu kenarını temsil etmektedir.

\section{Linyit toplam kalınlık haritası} hazırlanırken ve MTA, TKİ, TPAO kuyu verileri bir arada değerlendirilirken aşağıdaki hususlar dikkate alınmıştır (Perinçek, 2010a, 2010b, 2010c; Perinçek ve diğ., 2011).

\begin{tabular}{clll} 
TPAO & \multicolumn{2}{l}{ kuyularında } & Danişmen \\
Formasyonu'ndan & sadece & kesinti & numunesi
\end{tabular}

alınmıştır. Karot alınmaması nedeniyle kuyu veriler bazı yanılgılar içermektedir. TPAO kuyularında ayrıca linyit oranı yüksek kiltaşı düzeyleri linyitli şeyl, linyitli kiltaşı seviyeleri de linyit olarak işlenmiştir. Bunların sonucu olarak kuyularda kesilen linyit kalınlıkları kompozit kuyu loglarında gerçeğinden daha kalın gösterilmiştir. TKİ ve MTA kuyularında ise linyitli seviye geçilirken karot alındığı için kuyuda kesilen linyit kalınlığı ile ilgili olarak güvenilir değerler elde edilmektedir. Bu çalışmada TPAO kuyularından alınan linyit kalınlıkları yakınındaki TKİ ve MTA kuyularındaki kalınlıklar dikkate alınarak revize edilmiş ve azaltılarak kullanılmıştır. 
Çalışmanın ilk aşamasında, Trakya Havzası'nda kuyu korelasyonu yapılmış ve bu korelasyon sirasinda bazı MTA ve TKI kuyularında TPAO kuyularında kesilen daha alttaki linyit zonlarına, kuyu derinliğinin yeterli olmaması nedeniyle ulaşılmadığı anlaşılmıştır. TPAO kuyularında derinde kesilen linyit düzeyleri kalınlık haritalarında hesaba katılmamıştır. $\mathrm{Bu}$ nedenle, burada sunulan linyit kalınlık haritalarındaki değerler minimum kalınlıklardır.

Trakya Havzası kuzey kesiminde kuyu verilerinin çok yoğun olması, kuyu karotlarının olması nedeniyle linyit katkılarının kalın olduğu kesimler ileriye dönük yatırımlar için güvenilir değerlerdir. Bu alanlardaki kalınlık değişimleri Danişmen Formasyonu'nun çökelme havzasındaki fasiyes dağılımlarını yansıtmaktadır.
Örneğin Şekil 22’nin bazı kesimlerinde linyitin bulunmaması fasiyes nedeniyledir. $\mathrm{Bu}$ haritada linyit kalınlığını kontrol eden yapısal faktörler çok sinırlıdır.

Danişmen Formasyonu içindeki linyit katkılarıçoğunlukla formasyonun ortakısımlarında ve bazı alanlarda da tabana yakın yer almaktadır. Danişmen Formasyonu'nun aşındırıldığı bölgelerde birimin ortalarında bulunan linyit katkıları da aşındırılmıştır. Dolayısıyla Danişmen Formasyonu'nun ince olduğu kesimlerde linyit yoktur veya linyit olasılı̆̆ 1 azdır.

Linyit katkıları çoğunlukla marn içinde yer alır. Çakıllı, kumlu kireçli düzeyler linyit içermez. Ayrıca kuyu loglarında şeyl olarak tanımlanan seviyelerinin hakim olduğu alanlarda da linyit görülmemiştir

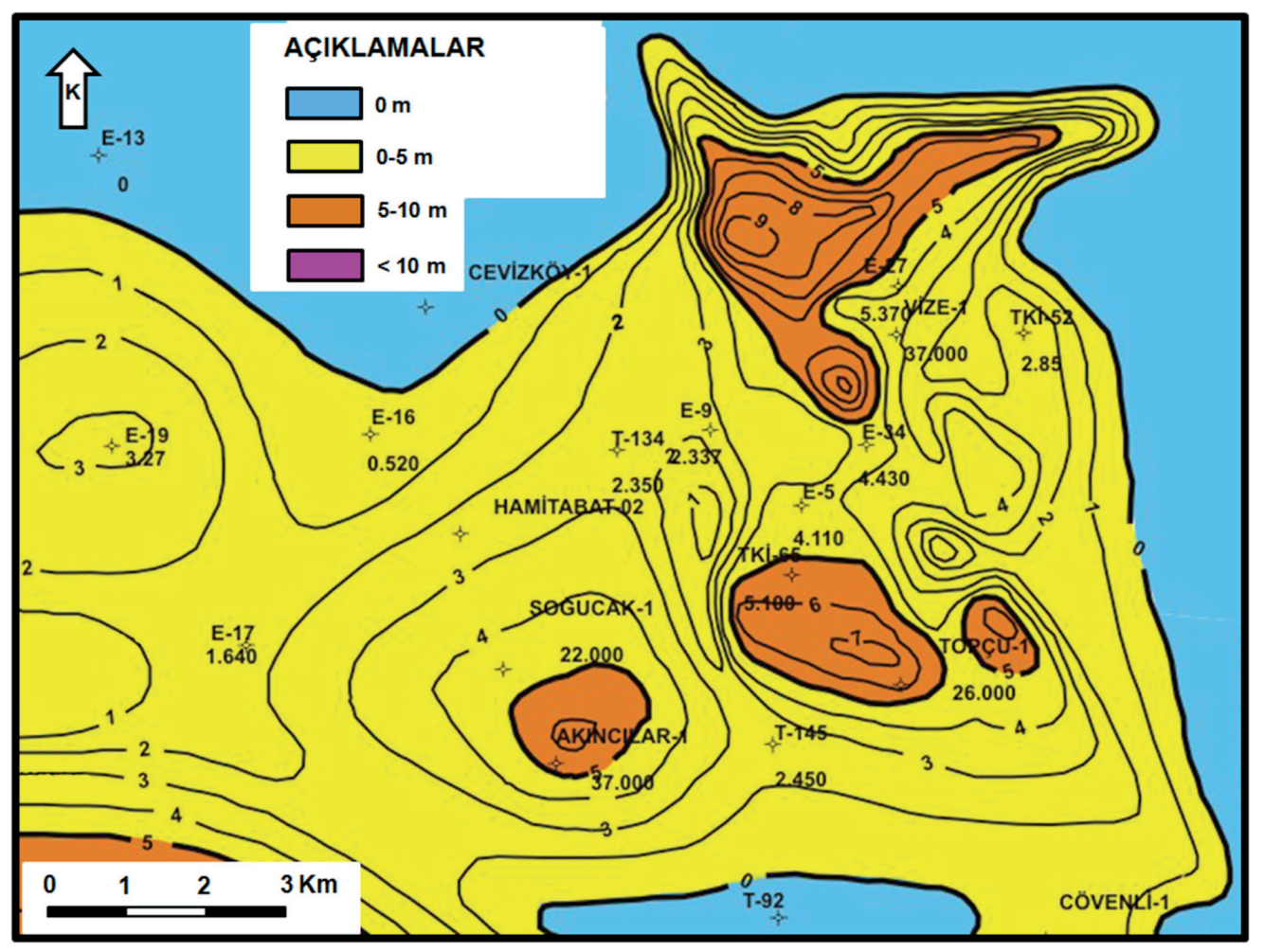

Şekil 24. Topçu-1, Vize-1 kuyuları dolayında bulunan ruhsat alanı ve dolayının toplam linyit kalınlık haritası. Lokasyon için Şekil $21^{`} \mathrm{e}$ bakınız.

Figure 24. Total thickness map of the lignite in southwest of Kirklaraeli-Pinarhisar area around Bayramdere-1, Yanciklar-1, Ceylan-1 wells. See Figure 21 for location. 
TKİveMTAverileriylehazırlanan haritada (Şekil 21) toplam linyit kalınlığının kuzeybatıdan (Şekil 23) güneydoğuya doğru (Şekil 27) genelde arttığ1 görülmektedir. Kırklaraeli-Pınarhisar güneybatısında Bayramdere-1, Yancıklar-1, Ceylan-1 kuyuları dolayında toplam linyit kalınlık haritasında (Şekil 23) maksimum toplam linyit kalınlığı 5.7 metredir. Buradaki kalınlık haritasının genel trendine bakıldığında linyitin çökeldiği bataklık veya göl alanının güneydoğukuzeybatı uzandığı söylenebilir. Söz konusu trend Trakya Havzası'nın kuzey kenarını oluşturan şelf ile uyumludur ve bu yapıyı sinırlayan Kırklareli Fay Zonu'na paralel olduğu söylenebilir.

Vize ruhsatlarında açılan kuyularda kesilen linyit seviyelerinin her bir kuyu için toplamı alınarak yukarıda verilen şekildeki toplam linyit kalınlık haritası elde edilmiştir (Şekil 24). Bu amaçla TKİ ruhsatlarında açılan kuyuların korelasyonundan elde edilen bilgilerden yararlanılmıştır (Şekil 13 ve Şekil 14).

Şekil 24 de verilen harita ve Şekil 13 ve Şekil 14'te verilen korelasyonlar ile ilgili sonuçlar aşağıda sıralanmıştır.

İki ruhsat alanı batı yarısında toplam linyit kalınlığ 10 m değerine yaklaşmaktadır. Linyitin 5 $\mathrm{m}$ ve daha kalın olduğu alanlar dikkate alınarak bu ruhsatların güneybatısında kalan alanda (Soğucak ve Akıncılar kuyuları dolayı) arama yapılması uygun olacaktır.

Ruhsat alanı yakın güneybatısında bulunan Soğucak -1, Akıncılar-1 ve Topçu TPAO kuyularında deniz seviyesinin altında $-62 \mathrm{~m}$ ve $-192 \mathrm{~m}$ düzeyleri arasında linyit düzeyleri gösterilmiştir. Ayrıca bu kuyularda $+62 \mathrm{~m}$ ve $-16 \mathrm{~m}$ arasinda kesilen linyit düzeyleri bulunmaktadır. Bu linyit düzeylerinin TKİ65 kuyusunda kesilen linyit düzeyi ile korelasyonu yapılabilmektedir. $\mathrm{Bu}$ durumda ruhsat alanının batı ve güneybatısında daha derinde $-62 \mathrm{~m}$ ve $-192 \mathrm{~m}$ arasinda ilave linyit seviyeleri beklenmektedir. $\mathrm{Bu}$ sonuca TPAO kuyularında gözlenen linyit seviyeleri dikkate alınarak varılmıştır. Bu durumda ruhsat alanı batısında TKİ-46 kuyusunun kuzeydoğusunda ve TKİ-61 kuyusunun kuzeybatısında iki adet kuyu açılıp TPAO kuyularında alt seviyelerde gözlenen linyit seviyelerinin var olup olmadığı test edilmelidir.

Haritanın ortasına yakın alanda linyit kalınlığının birden bire incelmesi, buradaki konturların sık olması ve bu sıklığın çizgisellik sunması nedeniyle buraya yaklaşık kuzeygüney doğrultulu bir fay beklenebilir. Fay olarak düşünülen alanda linyitin çökeldiği bataklık veya göl alanını batıdan sınırlayan yükssek açılı bir yamaç söz konusu da olabilir. İşletme aşamasında bu konuya dikkat edilmeli ve geliştirme planı buna göre şekillendirilmelidir.

$\mathrm{Bu}$ alanda ruhsatların kuzeyinde ve kuzeybatısında ve doğusunda linyit yoktur. Linyitin olmaması ortam koşullarıyla ilgilidir. Kuzeyde linyitin olmaması ise bu alanın havza dışında olmasıyla izah edilebilir.

Şekil 25'in ortasında sinırlı bir alanda linyit kalınlığı $5 \mathrm{~m}$ yi geçmektedir. Saray sahasının kuzeydoğu kesiminde linyit yoktur (Şekil 25 ve 26). Burada linyitin bulunmaması bu alanın havza dışında olmasıyla ilgilidir. Şekil 25 ve 26 da güneydeki alanlarda linyit olmamasının nedeni ise ortam koşulları farklılığı nedeniyledir. Büyükyoncal1-1 kuyusu yakınında ve haritanın güneydoğu kenarında toplam linyit kalınlığ1 $10 \mathrm{~m}$ den fazla, Çalıbel-1 kuyusu dolayında da ise $5 \mathrm{~m}$ den fazladır (Şekil 26). TPAO tarafindan delinen Büyükyoncalı-1 kuyusu TKİ Saray ruhsat sınırının hemen dışındadır. Söz konusu kuyu kuzeyinde TKI ruhsatları bulunur. Burada toplam linyit kalınlığ 5-8 m arasında değişmektedir. Ruhsatlardan biri (ER-2416938) içinde açılacak kuyularda kalın linyit katkıları kesilmesi beklenmektedir.

Vize ruhsatları ile Saray ruhsat karşılaştırıldığında Vize ruhsatlarının daha verimli olduğu görülür. 


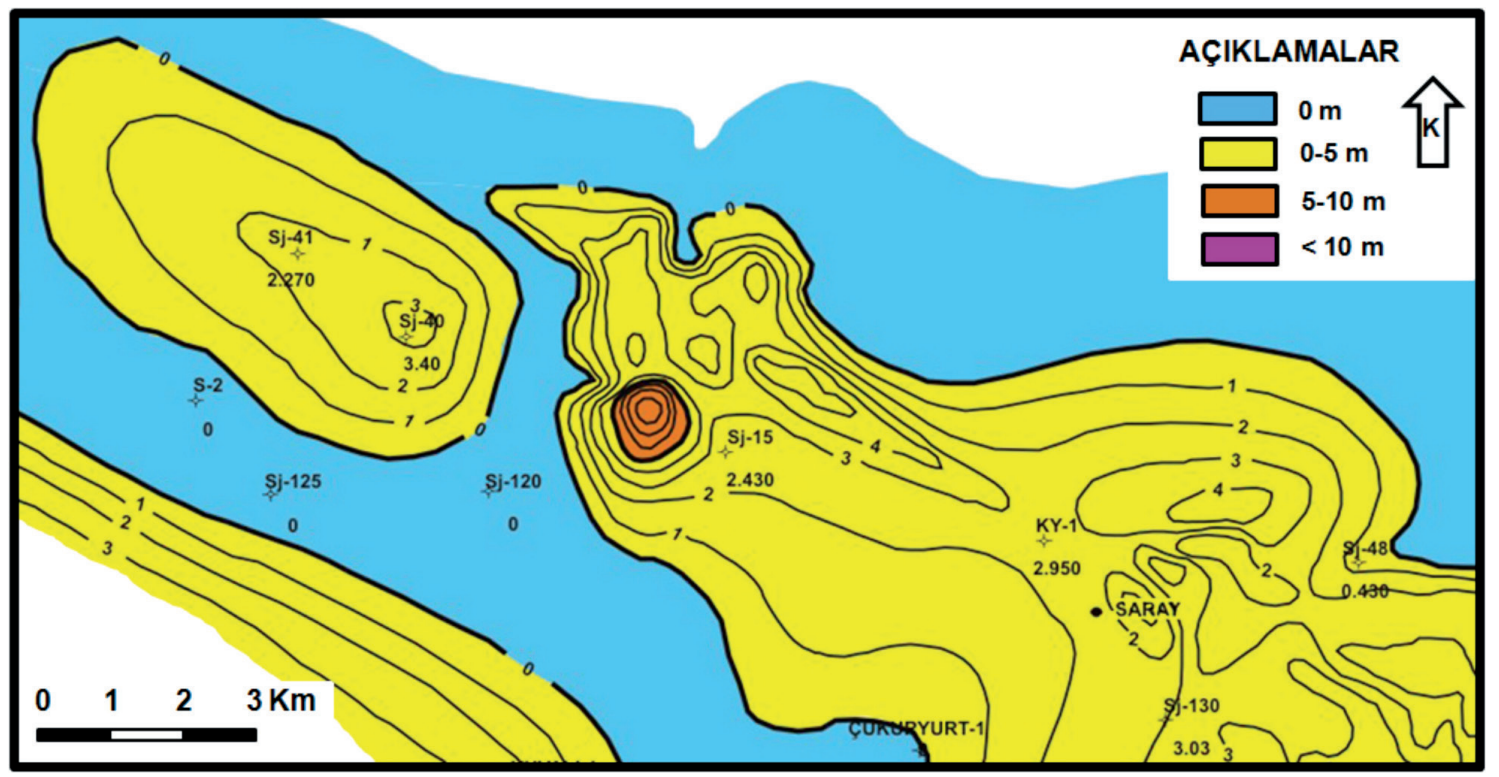

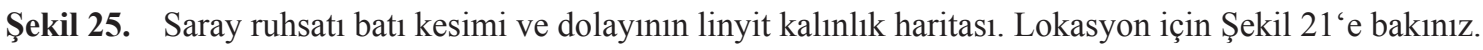

Figure 25. Total thickness map of the lignite in western portion of the Saray permit and surrounding area. See Figure 21 for location.

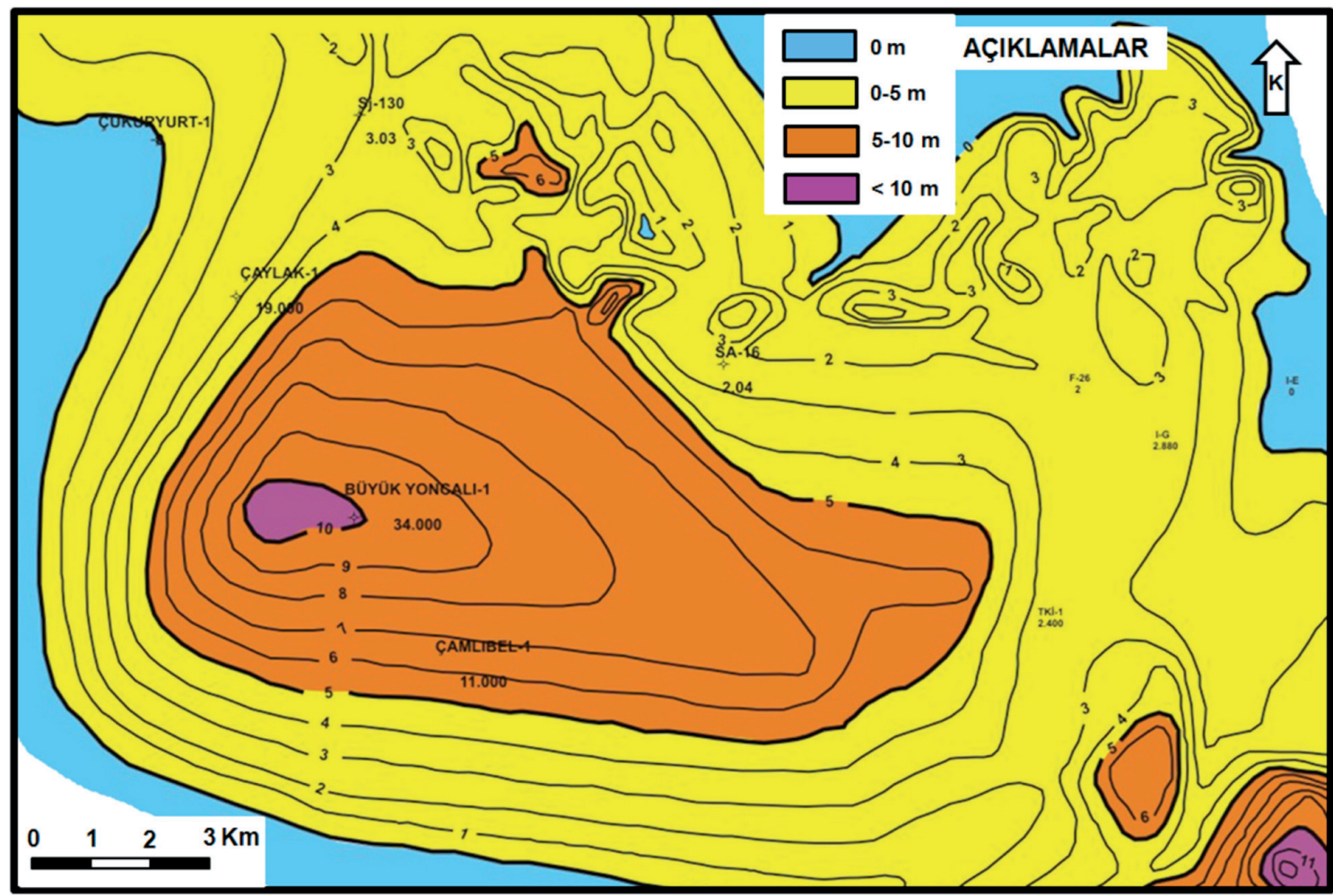

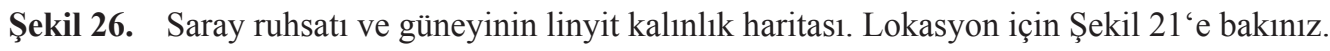

Figure 26. Total thickness map of the lignite in the Saray permit and south of permit area. See Figure 21 for location. 


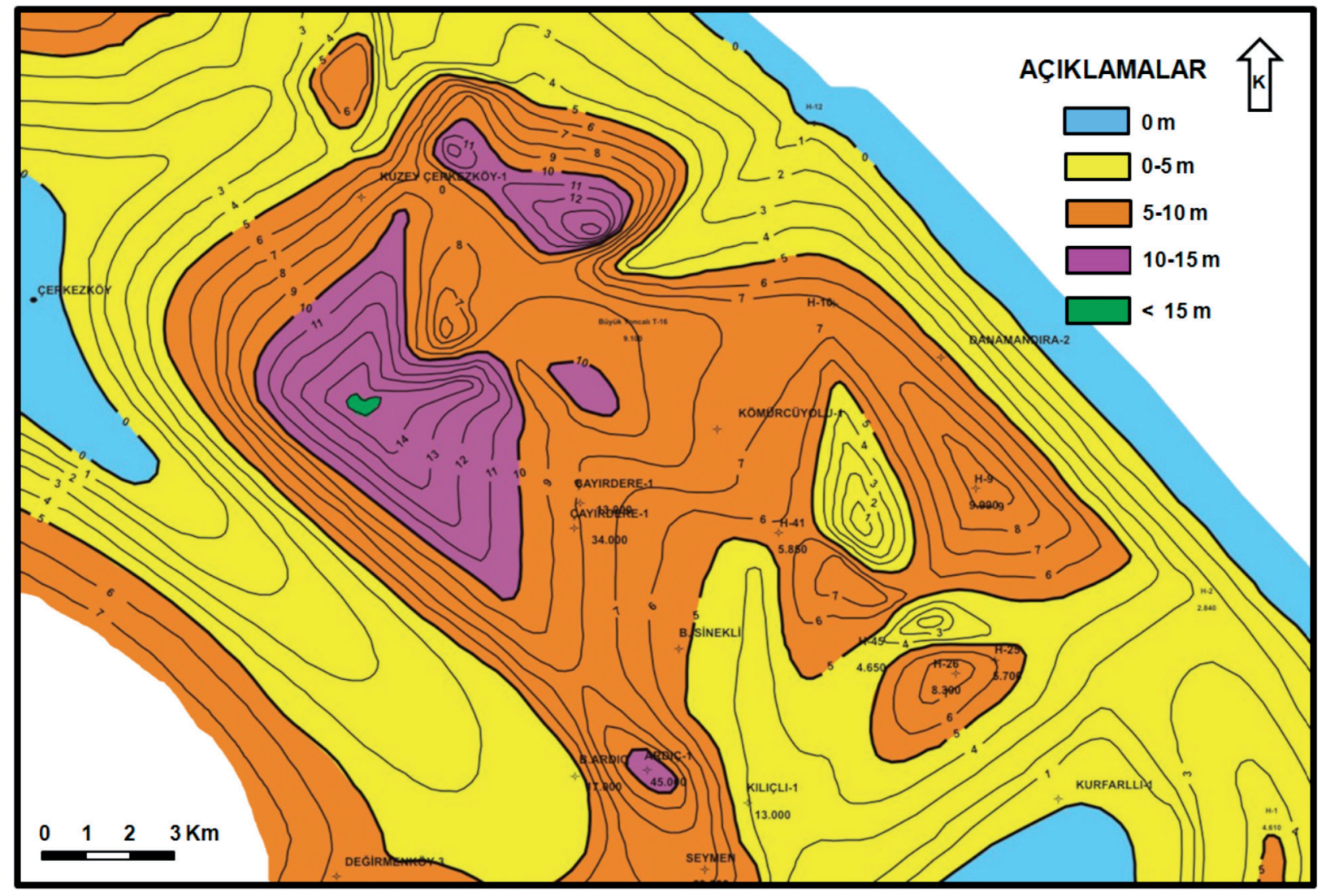

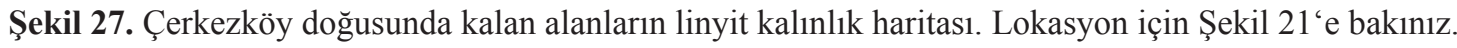

Figure 27. Total thickness map of the lignite in east of Çerkezköy area. See Figure 21 for location.

Trakya havzasinda bilinen toplam linyit kalınlığının en iyi olduğu alan Çerkezköy doğusudur (Şekil 27). Kuzey Çerkezköy-1, Danamandıra-1Sinekli-1, Beyciler-1 kuyuları arasında kalan alan da toplam linyit kalınlığ 5 metreden iken, Çayırdere-1 kuyusu batısında kalınlık 15 metreye ulaşır (Şekil 27). Söz konusu alanın güneyinde çok az sayıdaki kuyuda linyit kesilmemiştir.

Danişmen Formasyonu üzerine açısal uyumsuzlukla gelen Ergene Formasyonu çökelimi öncesi, Danişmen Formasyonu ile birlikte altındaki Eosen-Oligosen yaşlı birimler kıvrımlanmıştır. Kıvrımlanma sonrası özellikle kıvrımlanmaya neden olan fay zonları boyunca ve bu fay zonlarının oluşturduğu an-eşhelon yapılar üzerinde önemli oranda aşınma olmuştur. $\mathrm{Bu}$ aşınma nedeniyle Trakya Havzası'nın bazı kesimlerinde Danişmen Formasyonu tümüyle yok olmuştur. $\mathrm{Bu}$ nedenle Ergene Formasyonunun doğrudan Danişmen Formasyonu altındaki Osmancık Formasyonu üzerine, diskordansla oturduğu görülür. $\mathrm{Bu}$ sebeple Kumrular, Kocagöl, Dikilitaş, Mesutlu kuyu ve sahalarında Danişmen Formasyonu incedir veya Hamitabat sahası dolayında tümüyle aşındırılmıştır (Şekil 23, 24). Şekil 24'de verilen toplam linyit kalınlık haritasında, linyitin yukarıda siralanan alanlar dolayında ve Hayrabolu kuyuları ve Trakya Havzası'nın kuzeybatısında yer alan Haznedar, Akbaş, Habiller kuyuları dolaylarında hiç bulunmadığı saptanmıştır. 
Toplam linyit kalınlık haritasının (Şekil 21) kuzey kesimi kuyu verilerinin ve karotların çok yoğun olması nedeniyle detaylı işlenmiştir. Söz konusu alanlarda linyit katkılarının olmadığı veya kalın olduğu alanlar belirgindir ve güvenilir veri sağlamaktadır. $\mathrm{Bu}$ alanlardaki kalınlık değişimleri Danişmen Formasyonu'nun çökelme havzasındaki fasiyes dağılımlarını göstermektedir. Şekil 21'in kuzeydoğusunda linyitin bulunmaması genellikle ortam koşulları nedeniyledir. Bu haritada linyit kalınlığını kontrol eden yapısal faktörler çok sınırlıdır. Fakat aynı yorumu orta ve güney Trakya için söylemek mümkün değildir. Orta ve güney Trakya'da linyit katkılarının olmadığı alanlar KAF'1n Trakya'daki devamı olan Trakya Fay Sistemi (Kırklareli, Lüleburgaz, Babaeski Fay Zonları) nedeniyle yükselen ve aşınan alanlarıdır. Dolayısıyla Trakya Havzası'nın orta ve güneyinde linyit kalınlığ 1 Danişmen Formasyonu'nun fasiyes değişimlerini tam yansıtmamaktadır. Buralarda linyitin olmaması genelde aşınma ve kısmen de ortam koşulları ile ilgilidir.

Kırklareli ve Lüleburgaz Fay Zonları boyunca yükselmeye bağlı olarak aşınma olmuş ve Danişmen Formasyonu'nun kalınlığı azalmıştır. Söz konusu iki fay arasında ise Danişmen Formasyonu'nun oldukça kalın olduğu görülür. Ayrica Lüleburgaz Fay Zonu'nun güneyinde de Danişmen Formasyonu kalındır. Danişmen Formasyonu içindeki linyit katkıları çoğunlukla formasyonun orta kısımlarında yer almaktadır. Danişmen Formasyonu'nun aşındırıldı ğı bölgelerde birimin ortalarında bulunan linyit katkıları da aşındırılmıştır (Perinçek ve diğ., 2014 baskıda).

Danişmen Formasyonu'nun çökelimi sırasında bataklık ve göl alanlarında linyit oluşurken çakıltaş1 ve kumtaş1 gibi litolojilerin biriktiği akarsu çökellerinin olduğu alanlarda linyit birikmemiştir.Şekil21'degösterilenalanlardalinyit olmamasının nedeni Danişmen Formasyonu'nda yanal yöndeki fasiyes değişimleridir. Şekil 21'de Demirhanl-1 kuyusu kuzeyinde Danişmen Formasyonu silttaşı, kumtaşı, çakıltaşı ile temsil edilirken güneye gidildikçe aynı birimlerin kil, silttaş1, marna geçtiği görülür. İstifte kum, iri kum ve çakıl azalmış marn, kil düşük enerji ortamında çökelmiştir. Söz konusu düşük enerji ortamı bataklıkların yer aldığı alanlardır. Dolayısıyla Demirhanlı 1 kuyusu güneyinde marn, kil içinde toplam kalınlığı 5 metreye kadar ulaşan linyit birikebilmiştir. Söz konusu haritada linyit kalınlığı 400-500 m gibi bir mesafe içinde 0 metreden 7 metreye ulaşabilmektedir. Bu hızlı değişim linyit aramalarında güçlükler çıkarmaktadır.

Danişmen Formasyonu'nun fasiyesinin linyit oluşumu için uygun ortam şartlarını içermemesi nedeniyle Hayrabolu kuyularının olduğu alanda linyit tespit edilmemiştir. Hayrabolu kuyuları dolayında linyit olmasa da Danişmen Formasyonu kalınlığ 600-1000 metreler arasında değişmektedir. Bu alan Trakya Fay Sistemi'nin oluşturduğu yükselimin güneyinde kalır. $\mathrm{Bu}$ nedenle linyit olmamasının sebebi fay sisteminin oluşturduğu yükselme ve buna bağlı aşınmayla ilgili olmayıp, Danişmen Formasyonu'nun çökelme ortamıyla ilişkidir.

Şengüler (2008) tarafından raporda Trakya Havzası kömürlerinin yayılımı, özellikleri, çökelim modeli yanında bölgede bilinen saha ve işletmelere de yer verilmiştir. Trakya Havzası'nın kömürleri; gölsel ortamların delta bataklıklarında çökelmiştir. Çökme hızının yüksek olması çökel kalınlığının fazla olmasına neden olmuş, bu ise kömür damarlarının korelasyonunu güçleştirmiştir (Şengüler ve diğ. 2000; Şengüler, 2013).

Özetle Danişmen Formasyonu içindeki linyit kalınlığını 2 önemli unsur kontrol etmektedir (Perinçek ve diğ., 2014 baskıda). Birinci neden Danişmen Formasyonu içindeki 
fasiyes değişimleridir. İkinci nedeni ise havzanın yapısal evrimiyle ilgilidir. Orta Miyosen'de Trakya Fay Sistemi aktivitesi nedeniyle gelişen yapısal yükselimler ve faylar boyunca önemli oranda aşınma gerçekleşmiştir. Danişmen Formasyonu'nun aşınmasına paralel olarak içindeki linyit katkıları da ortadan kaldırılmıştır.

\section{SONUÇLAR}

Trakya Havzası'nın tamamı için TKİ, MTA ve TPAO kuyu verileri kullanılarak, aşağıda sunulan çalışmalar gerçekleştirilmiştir. Trakya Havzası'nın tümünün linyit potansiyelini ortaya çıkarmak için ilk aşamada kuyu korelasyonları gerçekleştirilmiş ve bölgesel ölçekte haritalar yapılmıştır. Yeni bulgular sayesinde linyitin havzadaki dağılımı ve potansiyeli yanında havzanın evrimi ve petrol potansiyeli ilgili yeni yaklaşımların tartışılacağı bilgilere ulaşılmıştır.

Ergene-Kırcasalih formasyonlarının toplam kalınlığının Trakya Havzası tümünde değişimini öğrenmek için kalınlık haritası yapılmıştır. Bu haritada birimin 0-1400 metreler arasında değiştiği görülür. Haritaya göre Ergene Formasyonu kalınlığının 400 metreyi geçtiği alanlarda Danişmen Formasyonu içindeki linyit katkılarına ekonomik derinliklerde ulaşılması güçtür. $\mathrm{Bu}$ nedenle birimin 400 metreden kalın olduğu alanlardan uzak durulmalıdır.

TKİ kuyuları ve az sayıda TPAO kuyu verisi kullanılarak kuyu korelasyonları yapılmıştır. $\mathrm{Bu}$ korelasyonlardan elde edilecek veriler linyitin yanal ve düşey fasiyes dağılımlarının anlaşılmasını sağlamıştır. Korelasyonlar ayrıca bu çalışma sırasında yapılan harita ve verilerle birlikte değerlendirilmiş ve elde edilen sonuçlar 1şığında Trakya Havzasında linyit için ekonomik alanlar tespit edilmiştir. Linyit katkıları çoğunlukla marn içinde yer alır. Çakıllı, kumlu, kireçli düzeyler çoğunlukla linyit içermez. Ayrıca şeyl seviyelerinin hakim olduğu alanlarda da linyit görülmemiştir.

TKİ, MTA ve TPAO kuyu verileri kullanılarak Trakya Havzası'nın kuzeydoğu kesimi, Edirne-Kırklareli-Pınarhisar-Saray dolayları için linyit kalınlık haritası hazırlanmıştır. Trakya'da linyit dağılımın kısmen fasiyes kontrolünde geliştiği fakat Trakya Fay Sistemi’nin de linyit dağılımı kontrol ettiği bu çalışmayla ortaya çıkarılmıştır. Danişmen Formasyonu üzerine açısal uyumsuzlukla gelen Ergene Formasyonu çökelimi öncesi, Danişmen Formasyonu ve altındaki Eosen-Oligosen yaşlı birimler kıvrımlanmıştır. Kıvrımlanma sonrası özellikle kıvrımlanmaya neden olan fay zonları boyunca ve bu fay zonlarının oluşturduğu an-eşhelon yapılar üzerinde önemli oranda aşınma olmuştur. $\mathrm{Bu}$ aşınma nedeniyle Trakya Havzası'nın bazı kesimlerinde Danişmen Formasyonu tümüyle yok olmuştur. $\mathrm{Bu}$ nedenle bazı alanlarda Danişmen Formasyonu incedir veya tümüyle aşındırılmıştır. Trakya Havzasında linyit aramaları yapılırken özelikle Danişmen Formasyonu kalınlığı ve toplam linyit kalınlığı dikkate alınarak değerlendirme yapılmalı, arama programı buna göre şekillendirilmelidir.

Vize Güneybatısında yapilan korelasyonlara göre TPAO kuyularında 3 linyit düzeyi görülmesine karşın, TKİ kuyularında 2 linyit düzeyi gözlenmiştir. TPAO kuyu verilerine göre, bölgede daha derinde 3 . Bir linyit düzeyinin olduğu düşünülmektedir. Alanda açılacak daha derin kuyular sayesinde alttaki linyit seviyesinden de üretim yapılacak ve üretim kapasitesi önemli oranda artırılmış olacaktır. Benzer sonuçlara havzanın diğer kesimlerinde de görmek mümkün olabilir.

Çöpköy - Uzunköprü dolayında mostrada da ve kuyularda gözlenen çakıltaşı düzeylerinin oranı artıkça linyit potansiyeli azalmaktadır. 
$\mathrm{Bu}$ civardaki kuyuların çoğunda linyit katkıları genellikle marn içinde görülmektedir. Çöpköy - Uzunköprü dolayında çalışılan kuyularda kum, çakıl ve şeylin hakim olduğu litolojilerde linyit katkısı görülmemektedir. Eğer Danişmen Formasyonu üstten önemli oranda aşındırılmış ise bu aşınma çoğunlukla linyit katkılı marn düzeylerini ortadan kaldırmıştır. Linyit aramaları yapılırken Danişmen Formasyonu'nun üst kısmının aşırı aşındırıldığı yerlerden uzak durulmalıdır.

Buçalışmanın bulgularıkullanılarakhavza için yepyeni bir arama stratejisi oluşturulmuştur Buna göre Trakya Fay Sisteminin oluşturduğu yükselim alanlarına gidilmesi, bu alanlarda arama yapılması önerilmektedir. Yükselim alanları dolayında Danişmen Formasyonunun üstten kısmen aşındığı, üstteki Ergene Formasyonu'nun ince olduğu kesimler hedef alanlar olarak seçilmiştir. Bu yeni strateji yapılan bu çalışmanın en önemli sonuçlarından biridir. Bugüne kadar bu çalışmada önerilen yaklaşımla arama çalışmaları yapılmamıştır.

Korelasyonlar yap1lirken ve kuyu verileri ile birlikte sismik kesitler yeraltı jeolojisi değerlendirmelerinde kullanılmıştır. Böylece sismik veri, kuyu verisi ve yüzey jeoloji verisinin entegrasyonu sağlanmıştır. Havzada yapıla korelasyonları takiben Danişmen Formasyonu'nun fasiyesinin linyit birikimi için uygun olduğu alanlarda, sismik kesitler kullanılarak, linyit düzeylerinin yüzeye yakın olduğu yerler belirlenmiştir. Buralarda linyit arama kuyuları önerilmiştir. Ayrıca linyit için riski az arama alanları tespit edilmiştir.

$\mathrm{Bu}$ çalışmanın sonuçlarından biride Trakya Fay Sisteminin ilk oluşum yaş aralığının daraltılmış ve netleştirilmiş olmasıdır. Trakya Fay Sistemi Geç Oligosen-Erken Miyosen yaşı Danişmen Formasyonu'nun çökelmesini takiben
Orta Miyosen sonu - Geç Miyosen başlarında oluşmuştur. Fay zonunun oluşturduğu yükselim alanlarında Danişmen Formasyonu değişik miktarlarda aşınmıştır. Fay aktivitesini takiben $\mathrm{Geç}$ Miyosen yaşı Ergene Formasyonu çökelmiştir.

Yukarıda sıralanan, Trakya Havzası için üretilen haritalar ve korelasyonları içeren raporlar sonuçları ilgili kuruluşlara iletilmiştir. $\mathrm{Bu}$ çalışmanın 1şı̆̆ında Trakya Havzası için yeni bir arama stratejisi ve yeni çalışma alanları belirlenmiştir.

\section{KATKI BELIRTME}

$\mathrm{Bu}$ çalışmanın gerçekleşmesi için gerekli yeraltı jeolojisi veri setini TKİ, MTA TPAO'ndan sağlamıştır. TPAO tarafindan TKİ Kurumu'na verilen kuyu verileri ve diğer bilgiler olmadan bu değerlendirmenin olması mümkün olamazdı. Ekibimiz, sağlanan veri seti için TKİ, MTA ve TPAO kuruluşlarına ve çalışanlarına teşekkürü borç bilir. Ayrıca çalışmanın başlatılmasını sağlayan TKİ kurumuna ve yürütülmesi sırasında yardımlarını esirgemeyen projeye destek veren ve veri akışını sağlayan Ayhan Kösebalaban, İsmail Ergüder ve Yaşar Ünal arkadaşlarımıza teşekkürü borç biliriz

\section{EXTENDED SUMMARY}

The Thrace Basin is bordered by Istranca massif to the north, by the Rhodope massif to the west, and by the Sakarya continent to the south. The basin is a Tertiary basin located north of the Marmara Sea and underlined by metamorphic units in the north and partially ophiolitic rocks in the south. The basin is filled with Middle Eocene to Pliocene deposits. The Middle Eocene units are transgressive over the metamorphic basement complex. Transgression reached its maximum extent during the early Oligocene. This transgressive was followed by 
the Middle Oligocene-Early Miocene regressive cycle. The lignite seams bearing Danişmen Formation is product of regressive cycle. The Danismen Formation range in thickness from 0 to more than 1,500 meter in the central part of the basin and conformably overlie the Osmanctk Formation of Oligocene age. Continental deposits in the Danismen Formation consist of claystonemudstone, siltstone, sandstone, and conglomerate. In the basin area, these sediments have been deposited as alluvial-fan, deltaic flood-plain, lake, and marsh deposits.

The basin provoked by strike slip fault system during late Middle Miocene-early Late Miocene period and extensive structural deformation occurred. Some areas along the fault zone underwent extensive uplift and erosion. Elevated areas related the Thrace Fault System partially was eroded; however these areas were still paleohigh during the accumulation of Ergene Formation. Onlapping sequence of Ergene Formation is thinner on these areas.

At the top of the sequence, the Ergene Formation overlies different stratigraphic units, including Danişmen Formation, across an erosional unconformity. The Ergene and overlying Pliocene Kircasalih formations are composite of fine-to coarse-grained continental clastic.

Aims of this work are to understand lignite potential and economical values of lignite seam layers interbedding in the Danişmen Formation (Oligocene-Early Miocene). This work has been conducted using subsurface data; including numerous wells and several seismic lines. First step and objective is to map total thickness of coal seams and to find regional distribution. Lignite seam layers are usually located in middle and at the base of the Danişmen Formation. Also total thickness map of Ergene-Kircasalih formations prepared which overlie lignite bearing Danişmen
Formation. Thicknesses of these units are the obstacle to mine lignite layers. Thin overburden areas of lignite bearing Danişmen Formation are located by mapping thickness of overlying Ergene-Kircasalih formations. In addition, several stratigraphic correlations conducted to understand lateral continuation of lignite layers and sedimentary facies distribution of the Danişmen Formation. Correlation and subsurface mapping are useful to make decisions for lignite mining, such as where to drill wells in order to get large amount of lignite and economic yields. Seismic lines are also used to refine correlation and to select target exploration areas. Seismic lines also used to locate thin overburden areas for lignite seams. Geological and geophysical data integration are achieved using well data, seismic lines and surface data.

Thickness map of the Ergene-Kircasalih formations shows that total thickness of these units is between 0 to 1400 meters. If thickness of the Ergene-Kircasalih formations is greater than 400 meters, exploration for lignite in these areas would be uneconomical. Exploration should be conducted in the area if the overburden thickness is less than 400 meters. Limited thickness less than $400 m$ on the paleohigh along the Thrace Fault System and along the margin of the basin is providing promising conditions for lignite exploration.

Thickness variation and distribution of the lignite layers are controlled by two factors. One of them is facies of the Danişmen Formation and second is position of the Thrace Fault System. Uplift along the fault zone caused extensive erosion. Amount of erosion is variable. Upper portion of the Danişmen Formation and embedded lignite seams were partially or completely removed along the fault zone and on the en-echelon folds. Exploration should be conducted away from these 
areas. In the case of limited erosion, only upper portion of the Danismen Formation were removed near the fault zone. Lignite exploration could be conducted in such areas. Stratigraphic correlation shows that lignite imbedded mostly in claystone deposited in marshy environment. However, conglomerates, sandstone and siltstone bearing facies are not suitable for coal accumulation.

Several correlation conducted near the Vize area shows that third lignite layer could be exist in the lower part of the stratigraphic section of the Danişmen Formation. Third lignite layer are observed in deep TPAO wells. Further drilling in TKI wells in the south, targeting third lignite layer may improve lignite production by 35\%$50 \%$ in Vize area and in the basin.

The result and finding of this work has been used to create new exploration strategy in the Thrace Basin. The strategy suggests that exploration may be concentrated on the paleohigh created by Thrace Fault System where erosion of the Danişmen Formation is limited. In addition, the Ergene Formation is thin on the paleohigh, which facilitate exploration activity. Uplifted areas and paleohigh are selected as primary target areas for exploration. Besides lignite thickness map and stratigraphic correlation are used to select potential areas for coal mining. Seismic data also used to find layers of coal seams located near surface. Exploration permits and well location has been suggested in line with new strategy based on data integration.

Initially exploration activity in basin previously concentrated along the northeastern basin margin and also in the south of the Thrace Basin where lignite seams are outcropping at the surface.

One of the results of this work is to refine timing of Trace Fault System. Fault system was active during late Middle Miocene to early Late Miocene after deposition of the Danişmen Formation. Rate of the erosion is variable along the fault zone on Danişmen Formation. Late Miocene Ergene Formation was deposited on and sealed the Thrace Fault System. Fault reactivation is visible in seismic lines in the east, near Marmara Sea. Discordance surface at the base of the Ergene Formation is folded prior to early Pliocene.

\section{DEĞIINILEN BELGELER}

Akartuna, M., 1968. Armutlu yarımadasının jeolojisi. İstanbul Üniversitesi Fen Fakültesi Monografiler,20, 105 s.

Alişan, C., 1985. Trakya “I” Bölgesi'nde Umurca-1, Kaynarca-1, Delen-1 kuyularında kesilen formasyonların palinostratigrafisi ve çökelme ortamlarının değerlendirilmesi. TPAO. Araştırma Grubu Arşivi, yayınlanmamış teknik rapor, 386, $60 \mathrm{~s}$

Atalık, E., 1992. Depositional systems of the Osmancık formation in the Thrace Basin. Doktora Tezi Orta Doğu Teknik Üniversitesi, 343 s. (yayımlanmamış).

Ataman G., Buket, E. Ve Çapan, U. S., 1975. Could North Anatolian Fault be a paleo benioff zone? Bulletin of Mineral Research and Exploration, Institute of Turkey, no. 84, p.97-102.

Barka, A. ve Hancock, P., 1984. Neotectonic deformation patterns in the convex-northwards arc of the North Anatolian Fault Zone. In: Dixon, J.E., Robertson, A.H.F. (Eds), The Geological Evolution of the Eastern Mediterranean Region. Geol. Soc. London, pp. 763-773.

Barka, A., 1981. Seismo-tectonic aspect of the North Anatolian Fault Zone: Ph.D thesis, University of Bristol, Bristol England, $333 \mathrm{p}$

Batı, Z., Alişan, C., Ediger, V.Ş., Teymur, S., Akça, N., Sancay, H., Ertuğ, K., Kirici, S., Erenler, M. ve Aköz, Ö., 2002. Kuzey Trakya Havzası'nın Palinomorf, Foraminifer ve Nannoplankton Biyostratigrafisi, Türkiye Stratigrafi Komitesi Çalıştayı (Trakya Bölgesi’nin Litostratigrafi Adlamaları) Özleri, s. 14.

Batı, Z., Erk, S. Ve Akça, N., 1993. Trakya Havzası Tersiyer Birimleri'nin Palinomorf, Foraminifer ve Nannoplankton Biyostratigrafisi. TPAO Araştırma Grubu Arşivi, yayınlanmamış teknik rapor, 1947, $92 \mathrm{~s}$. 
Bergougnan H., 1975. Relations entre les édifices Pontique et Taurique dans le nord-est de l'Anatolie: Bulletin de la Société Géologique de France, v.17, 1045-1057

Bergougnan H., 1976. Structure de la Chaine Pontique dans le HautKelkit (nord-est de l'Anatolie): Bulletin de la Société Géologique de France, v.18, 675-686

Boer, N.P., 1954. Report on a geological reconnaissance in Turkish Thrace, September, December G.A. 25373.

Burke, W. F. and Ugurtaş, G., 1974. Seismic interpretation of Thrace Basin, in H. Okay and E. Dileköz, eds., Proceeding of second petroleum congress of Turkey: Association of Turkish Petroleum Geologists, 227-248

Canıtez, N., 1973. Yeni kabuk hareketlerine ilişkin çalışmalar ve Kuzey Anadolu Fay problemi: Kuzey Anadolu Fay1 ve deprem kuşağı sempozyumu, Maden Tetkik Arama Enstitüsü Dergisi özel sayı. Ankara, Türkiye, 35-56.

Çağlayan, M.A. ve Yurtsever, A., 1998. Burgaz-A3, Edirne-B2 ve B3; Burgaz-A4 ve Kırklareli-B4; Kırklareli-B5 ve B6; Kırklareli-C6 paftaları, 1:100 000 ölçekli açınsama nitelikli Türkiye jeoloji haritaları, No: 20, 21, 22, 23. Maden Tetkik ve Arama Genel Müdürlüğü, Ankara.

Doust, H. ve Arıkan, Y., 1974. The geology of the Thrace Basin, Türkiye İkinci Petrol Kongresi Tebliğleri Kitabı, s. 119136.

Ediger, V. Ş., 1982. Kuleli Babaeski sırtının (KB Trakya) Paleoortamsal incelemesi ve Kuzey Trakya havzasının hidrokarbon potansiyelinin değerlendirilmesinde yeni yaklaşım: Türkiye Petrolleri Anonim Ortaklı̆̆ basılmamıș teknik rapor no. 1995, 194s.

Ediger, V. Ş., 1988. Biga Yarımadası'ndaki kömürlü birimlerden alınan örneklerin palinolojik analizi, TPAO Araştırma Merkezi Grubu Arşivi, yayınlanmamış teknik rapor, 809.

Ediger, V.Ş. ve Alişan, C., 1989. Tertiary fungal and algal palynomorph biostratigraphy of the northern Thrace basin, Turkey. Review of Palaeobotany and Palynology, $58,139-161$.

Fourquin, C., 1979. L'Anatolie du nord-ouest, marge méridionale du continent Européen, historie paléogéographique, tectonique et magmatique durant le Secondaire et le Tertiaire: Bulletin de la Société Géologique de France, v. $17,1059-1070$.

Gerhard, J.E. ve Alişan, C., 1987. Palynostratigraphy, Paleoecology, and visual organic geochemistry Turgutbey-2, Değirmencik-3 and Pancarköy-1, Thrace Basin, Turkey. TPAO Araştırma Merkezi Grubu Arşivi, yayınlanmamış teknik rapor, $983,33 \mathrm{~s}$.

Gökçen, N., 1971. Güneydoğu Trakya'nın Paleojen stratigrafisinde ostracod'lar açısından yeni görüşler. Türkiye 1. Petrol Kongresi Bildirileri Kitab1, 81-85.
Görür, N. ve Okay, A.I., 1996. Fore-arc origin of the Thrace basin, northwest Turkey. Geologische Rundschau, 85, 662-668.

İmik, M., 1988. Kırklareli-C2-3 Paftası ve İzahnamesi, 1:100 000 ölçekli Türkiye Jeoloji Haritaları, Maden Tetkik ve Arama Genel Müdürlüğü, Ankara 10 s.

Kara, H., Tuncalı, E., Narin, R., Gürsoy, B. ve Dümenci, S. 1996. Trakya Tersiyer kömür havzası raporu. MTA Genel Müdürlüğ̈̈ Rapor No: 9974, Ankara, (yayımlanmamış).

Kasar, S. ve Eren, A., 1986. Kırklareli-Saray-Kıyıköy bölgesinin jeolojisi. TPAO Arama Grubu Arşivi, yayınlanmamış teknik rapor, $2208,45 \mathrm{~s}$.

Kasar, S., Bürkan, K., Siyako ve M., Demir, O., 1983. TekirdağŞarköy-Keşan-Enez bölgesinin jeolojisi ve hidrokarbon olanakları. TPAO Arama Grubu Arşivi, yayınlanmamıs teknik rapor, $1771,71 \mathrm{~s}$.

Keskin, C., 1974. Kuzey Trakya Havzası'nın Stratigrafisi, Türkiye İkinci Petrol Kongresi Tebliğleri Kitabı, s. 137 - 163.

Ketin, İ., 1957. Kuzey Anadolu Deprem Fayı: İstanbul Teknik Üniversitesi dergisi, İstanbul Türkiye, no. 15, 49-52

Ketin, İ., 1976. San Andreas ve Kuzey Anadolu fayları arasında bir karşı1laştırma: Tüekiye Jeoloji Kurumu Bülteni, Ankara Türkiye, v.19, 149-154

Kopp, K.O., Pavoni, N. ve Schindler, C., 1969. Geologie Thrakiens IV: Das Ergene-Becken. Beih zum Geol. Jahrb., Heft 76, 136 s., Hannover.

Lebküchner, R.F., 1974. Orta Trakya Oligosen'nin jeolojisi hakkında. Maden Tetkik ve Arama Enstitüsü Dergisi, 83, 1-29, Ankara.

MTA, 1988. 1/100 000 Ölçekli Türkiye Jeoloji Haritaları Serisi, Edirne - C2 ve C3 Paftaları. Maden Tetkik ve Arama Genel Müdürlüğ̈̈, Ankara.

MTA, 1998. 1/100 000 Ölçekli Türkiye Jeoloji Haritaları Serisi, Kırklareli - B52 ve B6 Paftaları, No: 22. Maden Tetkik ve Arama Genel Müdürlüğü, Ankara.

N.V. Turkse Shell, 1969. AR/NTS/837, 838 ve 839 hak sira no'lu arama ruhsatlarına ait terk raporu, TPAO Arama Grubu Arşivi, yayınlanmamış teknik rapor, 1468.

Öztunalı, Ö.,Üşümezsoy, Ş., 1979. Istranca Masifi'nin "Çekirdek" kayaçları ve petrojenetik evrimleri, TJK. İstanbul Üniversitesi Yerbilimleri Fakültesi özel sayı; Altınl Sempozyumu, 37-44.

Perinçek, D. ve Karslığlu, Ö., 2007. Çanakkale Boğazı'nın oluşumu ve Kuvaterner yaşlı birimlerin dağılımında fayların rolü. 60. Türkiye Jeoloji kurultayı Bildiri Özetleri, 16-22 Nisan, Ankara, 478-479.

Perinçek, D., 1987. Trakya Havzası Renç Fay Zonunun Sismik Özellikleri, Türkiye 7. Petrol Kongresi Bildirileri, 11-20 
Perinçek, D., 1991, Possible strand of the North Anatolian Fault in the Thrace Basin, Turkey - An Interpretation. AAPG Bulletin 75, $241-257$.

Perinçek, D., 2006. Marmara - Trakya havzalarının Yapısal Evrimi ve Fayların Zamansal Gelişimi. Çanakkale Onsekiz Mart Üniversitesi-GençJeo .(Jeoloji Öğrenci Topluluğu) Çanakkale, 27-38

Perinçek, D., 2010a. Trakya Havzası'nın Linyit İmkanları TKİ rapor Ocak 2010, 55s

Perinçek, D., 2010b. Trakya Havzası'nın Linyit İmkanları TKİ rapor Mart 2010, 37s

Perinçek, D., 2010c. Trakya Havzası'nın Linyit İmkanları TKİ rapor Aralık 2010, 51s

Perinçek, D., Ataş, N., Erensoy, E., Karatut, Ş. Kösebalaban, A., Ergüder İ., Ünal., Y 2011. Trakya Havzası'nın linyit potansiyeli ve bunu kontrol eden jeolojik faktörler. 64 . Türkiye Jeoloji kurultayı Bildiri Özetleri, 16-25-29 Nisan 2011, Ankara, 93-94

Perinçek, D., Ataş, N., Karatut, Ş. ve Erensoy, E., 2014. Trakya Havzası'nda, Danişmen formasyonu içindeki linyit katmanlarının potansiyelini kontrol eden jeolojik faktörler MTA Dergisinde baskıda.

Saner, S., 1985. Saros Körfezi dolayının çökelme istifleri ve tektonik yerleşimi, Kuzeydoğu Ege Denizi, Türkiye. Türkiye Jeoloji Kurumu Bülteni, 28, 1-10.

Saraç, G., 1987. Kuzey Trakya bölgesinde Edirne-Kırklareli-SarayÇorlu-Uzunköprü Derekebir yörelerinin memeli paleofaunası, Ankara Univ. Fen Bil. Enst. Jeo. Müh. Anabilim Dalı Yük. Lis. Tezi (yayınlanmamış)

Seymen, İ., 1975. Kelkit Vadisi kesiminde Kuzey Anadolu Fay Zonu'nun tektonik özelliği: İstanbul Teknik Üniversitesi Maden Fakültesi Yayınları, İstanbul, 1980, 192 p

Siyako, M., 2005. Trakya ve yakın çevresinin Tersiyer stratigrafisi, TPAO Arama Dairesi Arşivi, yayınlanmamış teknik rapor, 4608, $104 \mathrm{~s}$.

Siyako, M., 2006a. Trakya Havzası'nın Linyitli Kumtaşları, MTA Dergisi, 132, $63-73$.

Siyako, M., 2006b. Trakya Bölgesi Litostratigrafi Birimleri (Tersiyer Bölümü). Stratigrafi Komitesi, Litostratigrafi Birimleri Serisi-2. MTA Genel Müdürlüğü yayını. $70 \mathrm{~s}$

Siyako, M., Bürkan, K. ve Okay, A.I., 1989. Biga ve Gelibolu yarımadalarının Tersiyer jeolojisi ve hidrokarbon olanakları. Türkiye Petrol Jeologları Derneği Bülteni, 1, 183-199.

Sümengen, M. ve Terlemez, İ., 1991. Güneybatı Trakya yöresi Eosen çökellerinin stratigrafisi. Maden Tetkik Arama Dergisi, $113,17-30$.
Sütçü, E., Paker, S., Nurlu, Y., Kumtepe, P., Cengiz, T. 2009. Tekirdağ-Malkara havzasında CBS yöntemleriyle potansiyel kömür sahalarının belirlenmesine yönelik iki değişkenli istatistiksel yaklaşım. TMMOB Coğrafi Bilgi Sistemleri Kongresi, 02-06 Kasım 2009, İzmir, 8 s.

Şengüler, İ. 2008. Trakya Havzası Kömür Aramaları Projesi Raporu (2005-2006-2007 Yılı Sondajları), MTA Genel Müdürlüğü Rapor No: 11069, Ankara, (yayımlanmamış)

Şengüler, İ. 2013. Ergene (Trakya) Havzası'nın jeolojisi ve kömür potansiyeli. MTA Doğal Kaynaklar ve Ekonomi Bülteni Sayı 16, 109-114

Şengüler, İ., Toprak, S., Kara, H., Öner, A., Tuncalı, E. ve Kır, N. 2000. Güney Trakya Bölgesindeki Kömürlerin Petrografik İncelemesi ve Ortamsal Yorumu. Türkiye 12. Kömür Kongresi Bildiriler Kitabı, Karadeniz Ereğlisi, Zonguldak. 173-180.

Şengüler, İ., Akman, Ü., Taka, M., Dümenci, S., Kalkan, İ., Kır, N., Sulu, K. 2003. Güney Marmara Neojen Havzalarının Kömür Potansiyeli. 56. Türkiye Jeoloji Kurultayı Bildiri Özleri Kitabı, Ankara, 212-213.

Şentürk, K. Sümengen, M., Terlemez, İ., ve Karaköse, C., 1998a. Çanakkale- D3 Paftası, 1:100 000 ölçekli açınsama nitelikli Türkiye jeoloji haritaları, 63. Maden Tetkik ve Arama Genel Müdürlüğü, Ankara.

Şentürk, K. Sümengen, M., Terlemez, İ., ve Karaköse, C., 1998b. Çanakkale D4 Paftası, 1:100 000 ölçekli açınsama nitelikli Türkiye jeoloji haritaları, 64. Maden Tetkik ve Arama Genel Müdürlüğü, Ankara

Şentürk, K., ve Karaköse, C., 1987, Çanakkale Boğazı ve dolayının jeolojisi. Maden Tetkik ve Arama Genel Müdürlüğü, yayınlanmamış teknik rapor, 371, $207 \mathrm{~s}$.

Taner, F. Ve Çağatay, A., 1983. Istranca masifindeki maden yataklarının jeolojisi ve minerolojisi: Türkiye Jeoloji Kurumu Bülteni, Ankara, Türkiye, v.26, 31-40

Tatar, Y., 1975. Tectonic structure along the North Anatolian fault Zone, Northeast of Refahiye (Erzincan): Tectonophysics, v.29, 401-410

Temel, R.Ö. ve Çiftçi, N.B., 2002. Gelibolu Yarımadası, Gökçeada ve Bozcaada Tersiyer çökellerinin stratigrafisi ve ortamsal özellikleri. Türkiye Petrol JeologlarıDerneği Bülteni, 14 $17-40$.

Tokay, M., 1973. Kuzey Anadolu Fay Zonu'nun Gerde ile Ilgaz arasındaki kısmında gözlemler: Kuzey Anadolu Fayı ve deprem kuşağı sempozyumu, Maden Tetkik Arama Enstitüsü Dergisi özel sayı.

Turgut, S. ve Eseller, G., 2000. Sequence stratigraphy, tectonics and depositional history in Eastern Thrace Basin, NW Turkey. Marine and Petroleum Geology, 17, 61-100. 
Turgut, S., Siyako, M. ve Dilki, A., 1983. Trakya Havzası'nın jeolojisi ve hidrokarbon olanakları. Türkiye Jeoloji Kongresi Bülteni, 4, 35-46.

Turgut, S., Türkaslan, M. ve Perinçek, D., 1991. Evolution of the Thrace sedimentary basinand its hydrocarbon prospectivity. Spencer AM (ed) Generation, accumulation, and production of Europe's hydrocarbons. Special Publication of Eurapean Association of Petroleum Geoscientists, 1, 415-437.

Türkecan, A. ve Yurtsever A., 2002. İstanbul Paftas1, 1: 500000 ölçekli Türkiye Jeoloji Haritası Serisi. Maden Tetkik ve Arama Genel Müdürlüğü, Ankara.

Umut, M, İmik, M., Kurt, Z., Özcan, İ., Ateş, M., Karabıyıkoğlu ve M., Saraç, G., 1984. Edirne İli-Kırklareli İli-Lüleburgaz (Kırklareli İli)- Uzunköprü (Edirne İli) civarının jeolojisi.. Maden Tetkik ve Arama Genel Müdürlüğü, yayınlanmamış teknik rapor, 7604, $42 \mathrm{~s}$.

Umut, M, İmik, M., Kurt, Z., Özcan, İ., Sarıkaya ve H., Saraç, G., 1983. Tekirdağ, Silivri (İstanbul), Pınarhisar alanının jeolojisi. Maden Tetkik ve Arama Genel Müdürlüŭü, yayınlanmamış teknik rapor, 7349.
Umut, M, 1988b, Kırklareli-C4 Paftası ve İzahnamesi, 1:100 000 ölçekli Türkiye Jeoloji Haritaları, Maden Tetkik ve Arama Genel Müdürlüğü, Ankara $6 \mathrm{~s}$.

Umut, M., 1988a. Kırklareli-C5 Paftası ve İzahnamesi, 1:100 000 ölçekli Türkiye Jeoloji Haritaları, Maden Tetkik ve Arama Genel Müdürlüğü, Ankara $10 \mathrm{~s}$.

Ünal, O. T., 1967. Trakya jeolojisi ve petrol imkanları. TPAO Arama Grubu Arşivi, yayınlanmamış teknik rapor, 391, 80 s.

Üşümezsoy, Ş., 1982. Igneous and metamorphic geology and mineralization of Istranca region (Geotectonic setting and mineralization of the Istranca masif): İstanbul University Earth Sciences Review, v.3, no. 1-2, 227-294.

$\begin{array}{ll}\text { Makale Geliş Tarihi } & : \text { 28 Ağustos } 2014 \\ \text { Kabul Tarihi } & : \text { Aralı } 2014 \\ \text { Received } & : \text { 28 August } 2014 \\ \text { Accepted } & : \text { 8 December } 2014\end{array}$

